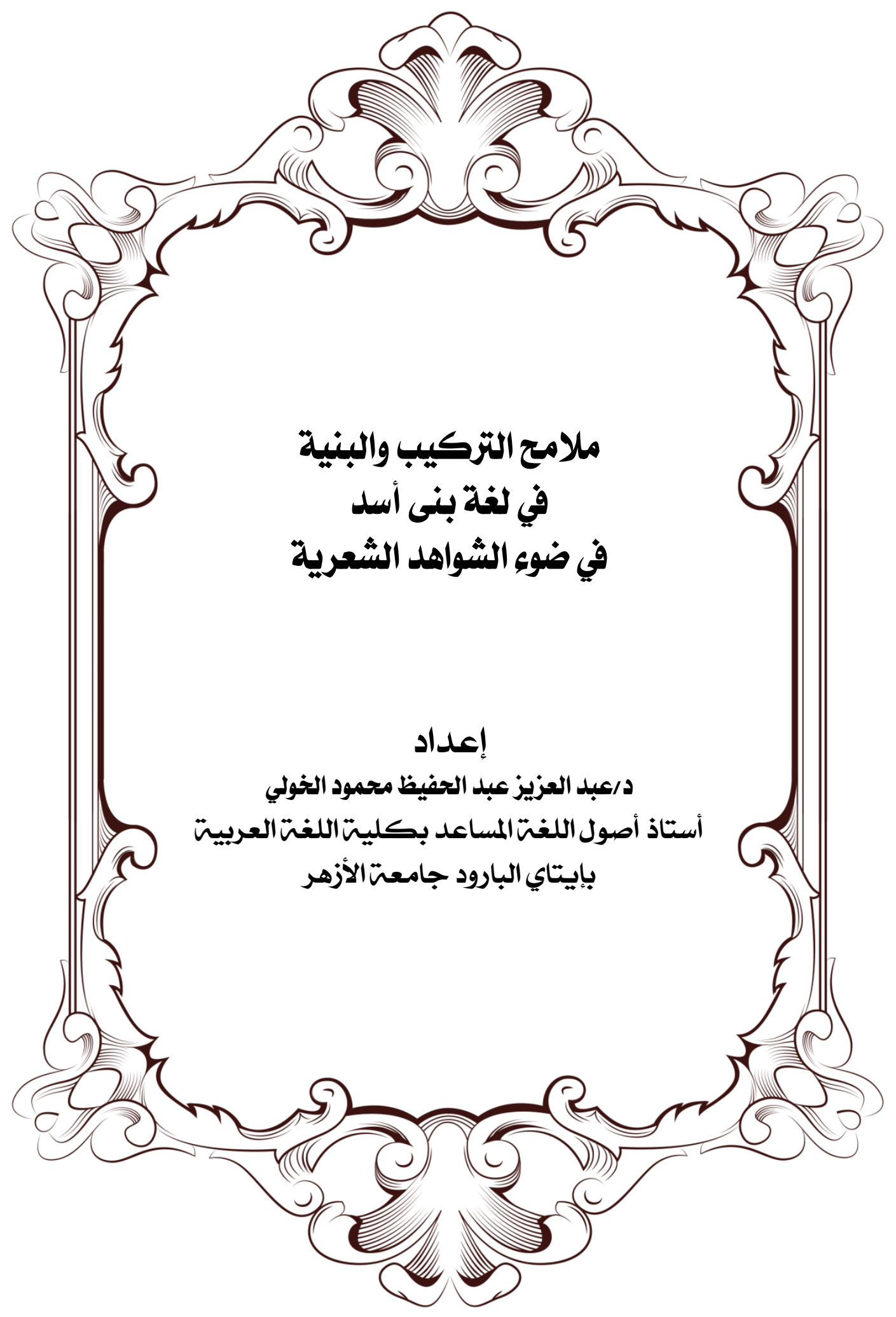




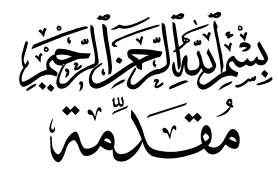

الحمد لله رب العـالمين والصـاة والسـلام على أثـرف الخلق وحبيب

الحق أفصح من نطق بالضاد محمد بن عبد الله وعلى آله وأصحابه وسلم.

\section{6 ويعد}

فإنـه لمـن البعـد عـن الصـواب أن تـدرس اللغــة بعيـدة عـن منابعهـا الأصلية، وروادفها المعينة التي تمد الدارس بمزبد من المرونة اللغوبية، والمادة الخصبة لدراسـتها؛ ومنـابع اللغـة متعددة وراوفدها كثرة متتوعـة، وبعد الثـعر العربي من أخصب نلاك المنابع فهو ديوان العرب، والجامع لأخبارها، والذاكر لحروبهـا وأيامهـا والحـافظ لمآثرهـا فالثـعر هـو الحامـل تلـك المعـاني بلغتـهـ المنطوقـة، والعلاقـة بـين الثـعر واللغــة وطيدة راسـخة وممـا يؤكد أن للثـعر

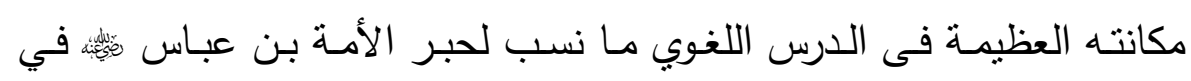
قوله: إذا أشكل عليكم الثيء من القرآن فأرجعوا إلى الثعر فإنه ديوان العرب، ومسن ثم كان اهتمـام العرب بالثـعر في جـاهليتهم وبعـ الإسـام؛ إذ كـانوا يحتفلون بالشعر ، ويجعلون له أسواقاً يتبارون فيها وبفتخرون فلا عجب أن يكون اهتمـام اللغوبين بالثـعر والاشتغال بـه واستتباط

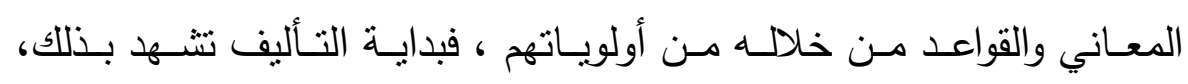

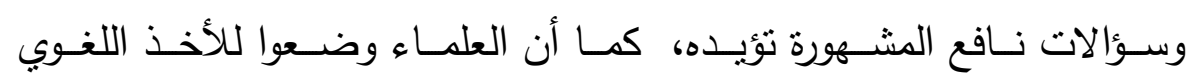
والاحتجاج شروطا حيث حددوا زمانا لهذا الأخذ، و حددوا له أماكن من جزيرة العرب فلا يأخذ من قبيلة دب فيها اللحن أو تاخمت في حدودها غير العرب حتى يضمنوا سلامة اللغة وبعدها عن الفساد ومخالطة الأعاجم، وكانت قبيلة أسد موضوع البحث في مقدمة القبائل التي أجاز العلماء الأخذ عنها لبعدها عن اللحن والعجمة نظرا لما فرضته الطبيعة البدوبة التي تسكن فيها وما تتمتع به من خشونة فى الطباع، فكان شعر شعرائهم مصدرا لذلك الاحتجاج اللغويّ. 
حوليت كليت اللغتّا العربيتبايتاى البارود (العدد التاسع والعشرون)

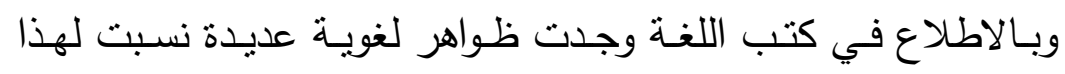

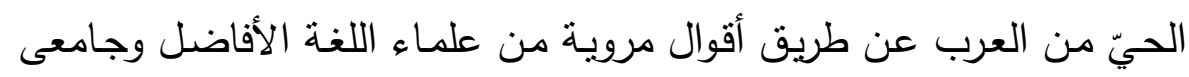

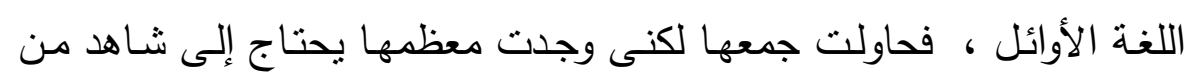

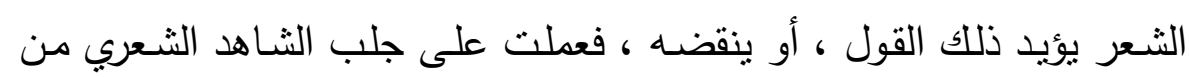
شعراء بني أسد لأربط بينه وبين القول المروى وذللك عن طريق استقراء شعرهم من خلال كتب اللغة والأدب والمعاجم إضافة إلى الاستعانة بدواوين شعرائهم

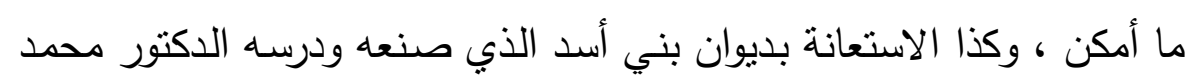
على دقة ، وكان دافعي إلى اختيار هذا الموضوع هو ربط الظـاهرة اللغوية المنسوبة لبنى أسد بالثـاهد الثعري والوقوف على مدى الارتباط بين الثـاهد

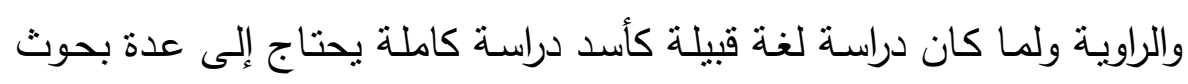
فقد سبق أن درست ظاهرة الإبدال اللغوي عند بني أسد بين الأقوال المرويـة والثواهد الثعرية دراسة صوتية في ضوء علم اللغة الحديث، وهذا البحث الذي لإني أنـا بصدد كتابته درست فيه التركيب والبنيـة في لغـة أسد من خـلا الثـاهد الشعري لديهم، وقد قام بعض الباحثين بدراسات سبقت دراستي عن لغة بني

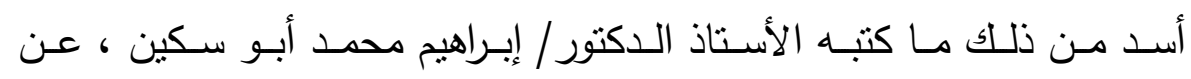

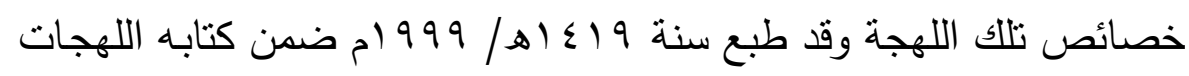
العربية والقراءات القرآنية كما كتب علي ناصر غالب كتابه: لهجة قبيلة أسد

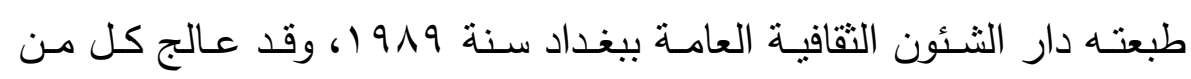
الباحثين اللهجة بشكل عام دونما ربط بالثـاهد الثعري؛ وقد جاءت معالجتي لتمزج بين الظاهرة اللغوية، والثاهد الثعري. وجاء البحث متضمنا الآتي: المقدمة: فيها ذكرت الهدف من اختياري البحث ، والمنهج الذي سرت عليهيه.

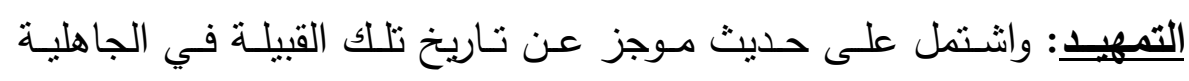
والإسلام. المبحث الأول: قمت فيه بدراسة قضايا التركيب في لغة بنى أسد. 


$$
\begin{aligned}
& \text { ملامح التزكيب والبنية في لغة بنى أسد في ضوء الشواهد الشعرية }
\end{aligned}
$$

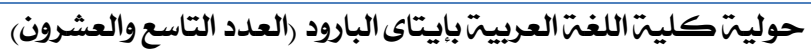

$$
\begin{aligned}
& \text { المبحث الثاني: قمت فيه بدراسة قضايا البنية. }
\end{aligned}
$$

وفي كلا المبحثين قمت بالاستشهاد على المسائل المتصلة بموضوع

البحث بشعر بني أسد وذللك من خلال ما أتيح لي من كتب اللغة، ودواوين

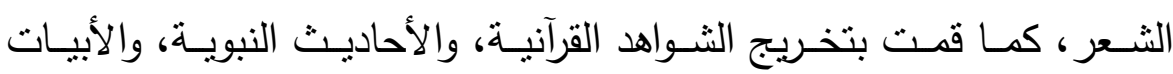
الشعرية المتصلة بموضوع البحث من خلال كتب اللغة. راجيا من الله تعالى أن أكون قد وفقت في كتابـة ما كتبت خدمـة للغة الضاد وطالبا من الله السداد و الله وليّ ذلك والقادر عليه.

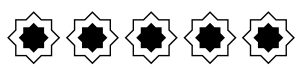
د ـ مبد العزيزعبد الحفيظ الحولم 
بنو أسد قبيلة عدنانية مضرية، وأسد هو : أسد بن خزيمة بن مدركة بن إلياس بن مضر بن نزار بن معد بن عدنان، وعدنان ينتهي نسبه إلي

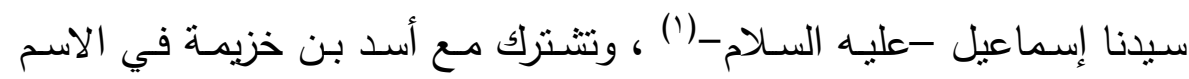

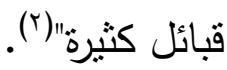

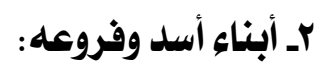

كان لأسد خمسة أبناءهم دودان وكاهل وعمرو وصعب وحلمه وقيل:

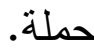

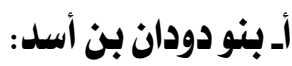

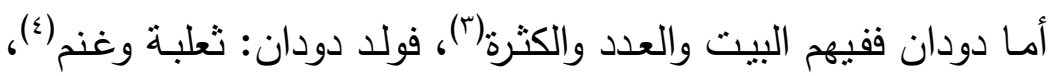

فولد غنم بن دودان هم: كبير وعامر وماللك، ومنهم عبد الله وأبو أحمد وعبيد

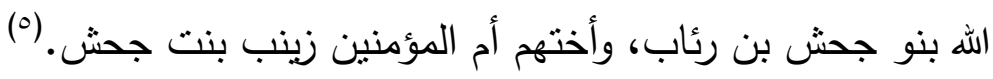

1 - ينظـر: جمهرة أنسـاب العرب لابـن حزم صل ال تحقيق عبد السـلام هـارون- دار

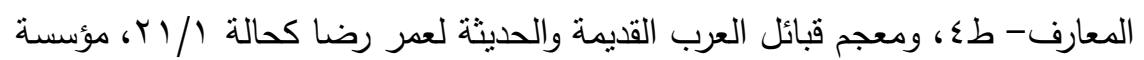

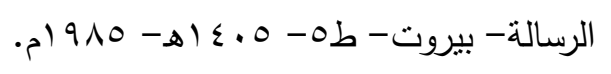

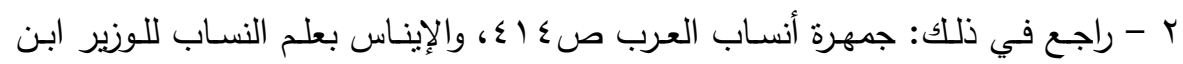

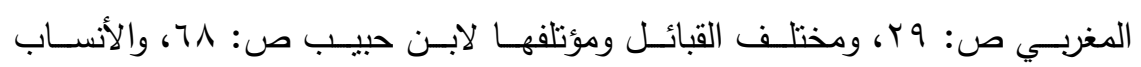

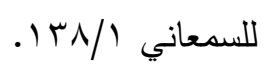

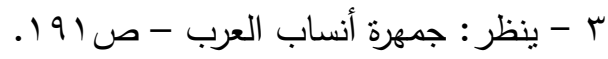

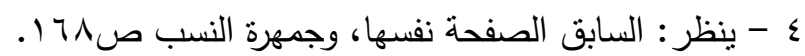

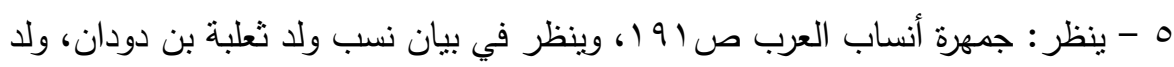

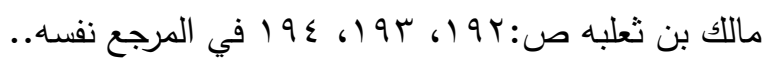


وأما كاهل بن أسد فولد مازنا، ومن بنيه علباء بن حارثة بن هلال -

وكان شاعرا- وهو الذي قتل حجر بن عمرو والد امرئ القيس (')

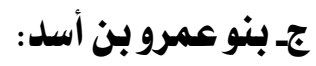

وأمسا ولد عمرو بن أسد فهم: المسيب ورهم والقليب والمليح وهاشم معرض- واسمه سعد- والهالك، وكان الهالك بن عمرو أول من عمل الحديد مـن العـرب، فعيـرت العـرب بني أسـد بـالقيون، ومـن بنـي معـرض: الأقثـر

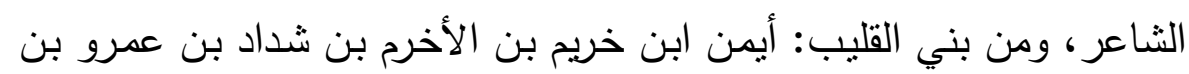

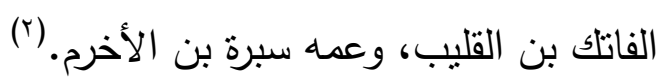

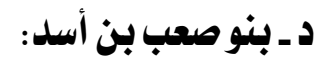

وولا صعب بن أسد عبد الله، ومن ولده: بنو النعامـة، وهم بنو جعدة،

وبنو البجير وهم بنو النخامـة، والنعامـة والبجير هما ابنا عبد الله بن مرة بن

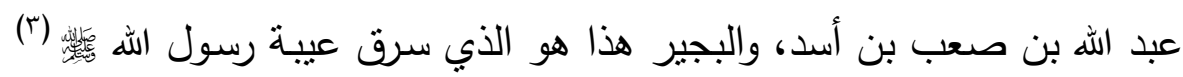
والعيبة زبيل من أدم يجعل فيه الثياب والمتاع.

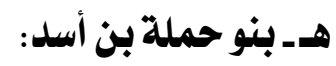

وأمـا بنو حلمـة فقد ذكر ابن عبد ربـه أن امرأ القيس أفناهم بأبيـه(؛)، وذكر غيره أنهم أهل أبيات في بني جذيمة بن مالك بن نصر بن قعين بن

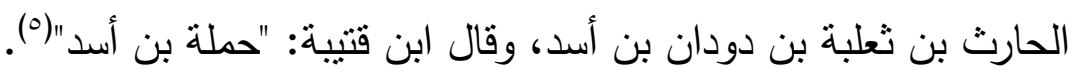

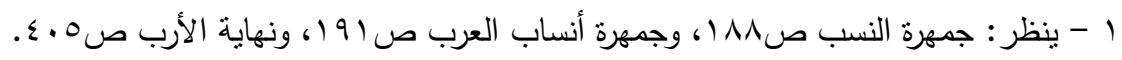

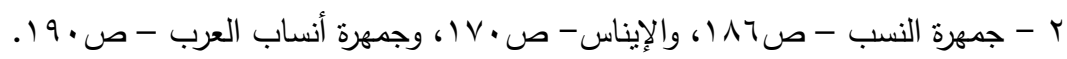

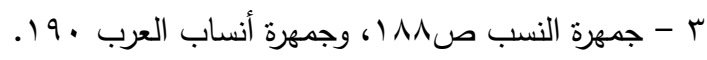

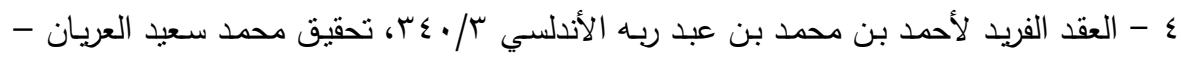
دار الفكر - بيروت- بدون.

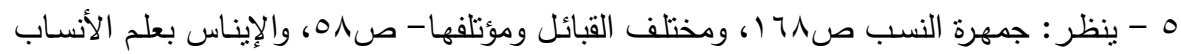

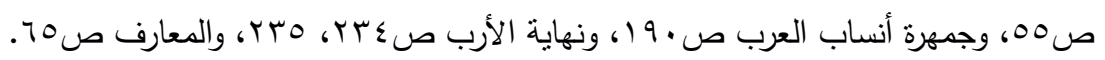




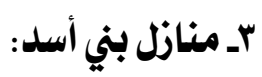

من المعروف أن حياة القبائل البدويـة تقوم علي الحل والترحال من

مكان إلي مكان تبعاً لمساقط الغيث ومنابت الكلأ، وكان هذا هو الحال مـع قبيلة بني أسد " فقد كانت الحجاز منازل مضر وربيعة ابني نزار بن معد بن

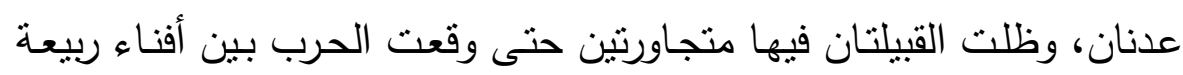
فارتحلت ربيعـة مـن مكـة نحسو اليمامسة ونجد ومـا صـاقبها، ثم إلي الجزيـرة الفراتية..... وانقسمت مضر إلي قيس عيلان وخندف، ثم احتربت القبيلتان، فرحلت قيس وبقي جذما خندف: طابخة ومدركة، ولم تلبثت أن رحلت طابخة

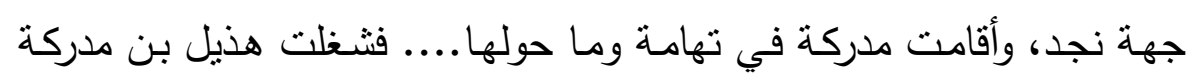

جبالاً من جبال السراة وصدور أوديتها وشِعابها" (').

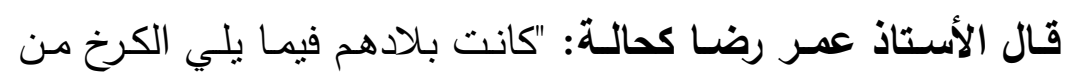
أرض نجد، وفي مجاورة طيئ، ويقال: إن بلاد طيءء كانت لبني أسد، خرجوا

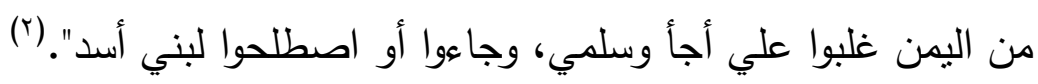

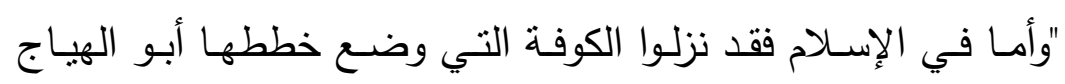
الأسدي بأمر من عمر بن الخطاب"(r)، "ولم ينزل أحد من بني أسد بن خزيمة البصرة، وأما خطة بني أسد التي بالبصرة فهي لبني أسد بن شريك بن مالك بن عمرو بن ماللك بن فهم، وليست بالبصرة خطة لبني أسد بن خزيمة"(أ).

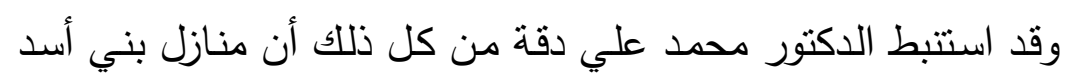

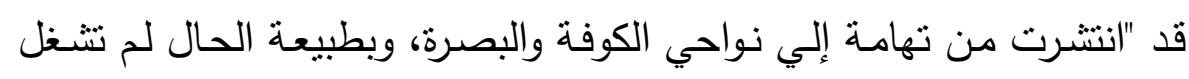

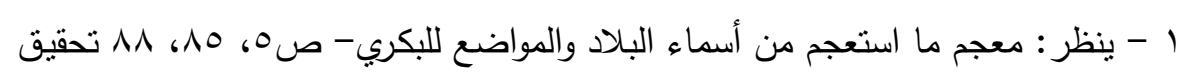

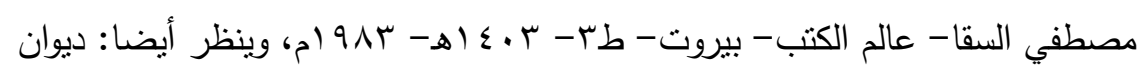

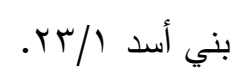

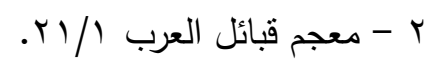

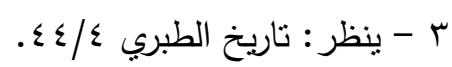

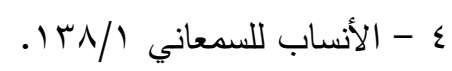


أسد تلكك الأرضين الواسعة، وإنما حلت أو ارتحلت في تلك المواطن، مجاورة

فيها غيرها من القبائل المقيمة والظاعنة في نجد والحجاز وتهامة"(').

\section{عـ لهجة بني أسد بيز اللهجات العربية}

عندما قام علماء اللغة الأوائل بتدوين اللغة، ورحلوا إلي القبائل للأخذ

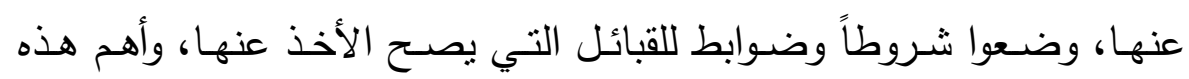
الضـوابط والثـروط: ألا تحدث مخالطـة بينها وبـين الأعـاجم، فكلمـا أوغلت القبيلة في البداوة، وبعدت عن الحواضر ، سلمت لغتها في آفة اللحن ولوثنة العجمة.

وقد كانت قبيلة بني أسد من هذه القبائل المتبديـة التي بعدت عن

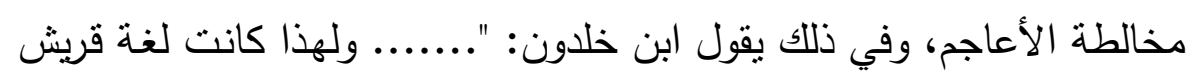
أفصح اللغات العربية وأصرحها؛ لبعدهم عن بلاد العجم من جميع جهاتهم، ثم دمان

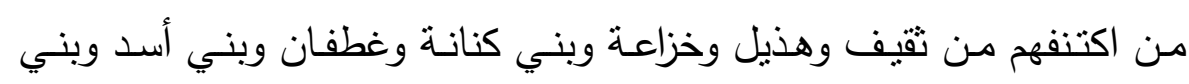

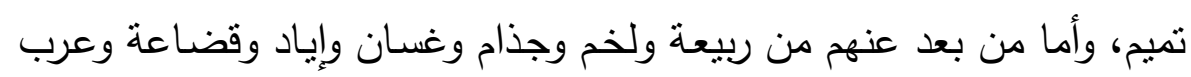

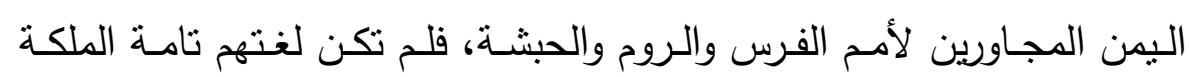

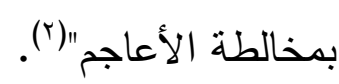

وقد حدد الفارابي هذه القبائل التي يصح الأخذ عنها، وذلك فيما نقله السيوطي عنه بقوله: "والذين عنهم نقلت اللغنة العربية، وبهم اقتدي، وعنهم أخذ اللسان العربي من بين قبائل العرب هم: قيس وتميم وأسد، فإن هؤلاء هم

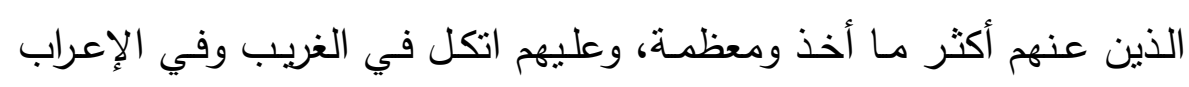
والتصريف، ثم هذيل وبعض كنانة وبعض الطائيين، ولم يؤخذ عن غيرهم من

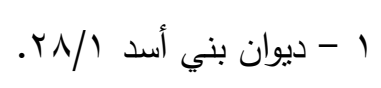

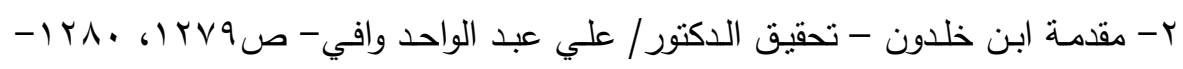

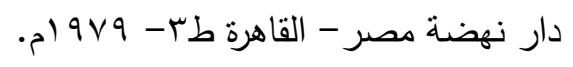


ملامح التركيب والبنية في لغة بنى أسد في ضوء الشواهد الشعرية

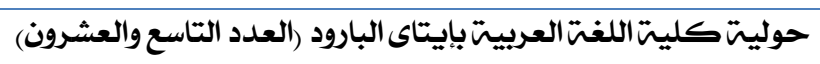

سائر قبائلهم، وبالجملة فإنه لم يؤخذ عن حضري قط، ولا عن سكان البراري ممن كان يسكن أطراف بلادهم المجاورة لسائر الأمم الذين حولهم"( ('). وبناء علي ذلك فإن لغة بني أسد من اللغات الفصيحة التي اعتمد عليها في جمع اللغة وتدوينها واستنباط قواعدها. -

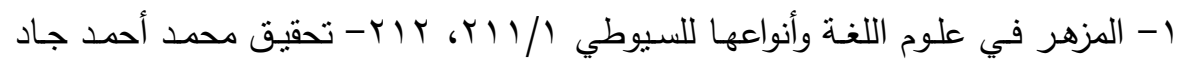
المولي وعلي محمد البجاوي، ومحمد أبو الفضل إبراهيم- دار إحياء الكتب العربية القاهرة - بدون. 
ملامح التزكيب والبنية في لغة بنى أسد في ضوء الشواهد الشعرية

حوليتّ كليتا اللغت العربيتبايتاى البارود (العدد التاسع والعشرون)

المبحسـث الأول

قضايـــا التركيــبـ

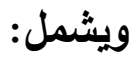

• اللغات في ضمير الغائب: (هو، هي).

• لغات الملحق بجمع المذكر السالم.

• مجىء المثنى بالألف في الأحوال الإعرابية المختلفة.

• إسناد القعل وشبهه إلى فاعل ظاهر .

• حذف نون (مِنْ) الجارة.

• حذف اللام والألف من (على) الجارة.

• الترخيم في غير النداء، أو ظاهرة القطعة.

• إسناد الفعل المضعف إلى ضمائر الرفع المتحركة.

• الاستثاء، وفيه مسألتان:

- الاستناء المنقطع

- - بناء "غير" مطلقا

$\hat{-} \hat{-1}$ 


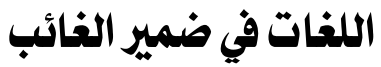

\section{(هو، هي) (هي)}

جـاء ضـمير الغائب للمفرد المـذكر: "هو"، وضـمبر الغائب للمفردة

$$
\text { المؤنثة: "هي" على أربع لغات عند العرب: }
$$

الأولـى: البنـاء على الفتح مـع التخفيف، فيقال: هوَ، هيَ، وهذا هو

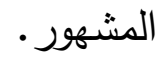

الثانيـة: نتـديد كل من الواو في "هوَّ"، واليـاء في "هيَّ" مـع الفتح،

\section{ونسبت لهمدان (')}

وقد استشهد العلماء على هذه اللغة بقول الثاعر:

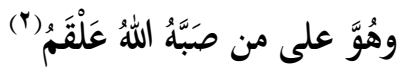

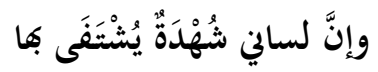

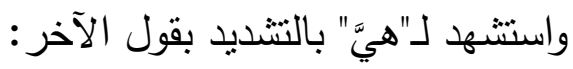

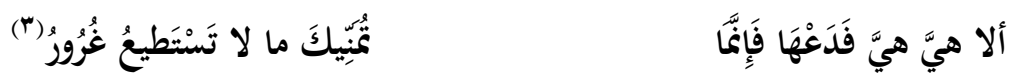

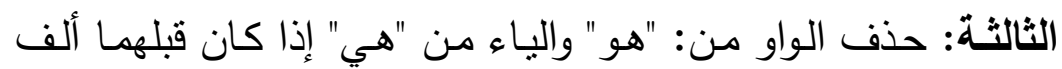

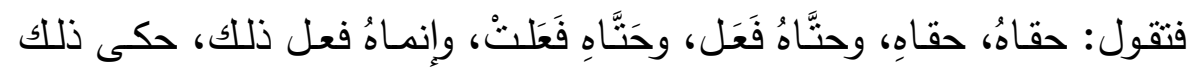

عنهم الكسائي فيما نقله ابن منظور ، والزبيدي(ء). الرابعة: إسكان الواو من "هو"، والياء من"هي"، وذللك في لغة ولة قيس فيس

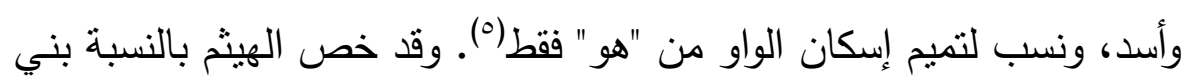
أسد، وأنشد:

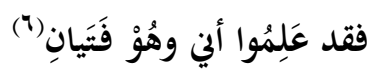

وكنّا إذا ما كان يؤْمُ كِريهةٍ

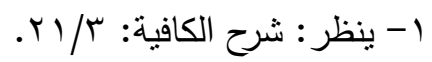

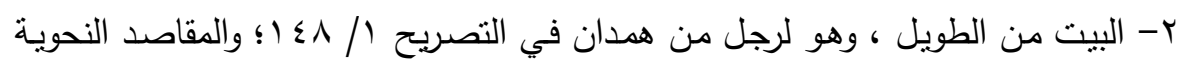
. $201 / 1$

r-البيت من الطويل، وهو بلا نسبة في التهذيب (ها)، ولسان العرب (ها).

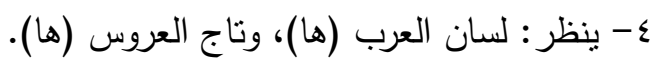
ه- ينظر : لسان العرب مادة "ها" عن اللحياني.

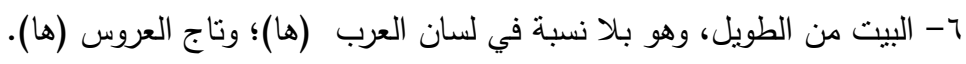


ملامح التزكيب والبنية في لغة بنى أسد في ضوء الشواهد الشعرية

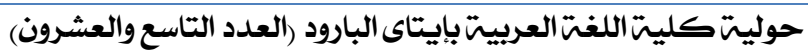

وقد اسنتهـ اللغويون على تسكين الياء من "هي" يقول الثاعر :

فإذاذا هيْ بعظامٍ ودَمَا (1)

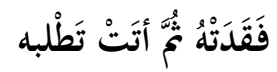

شعراء أسد وظاهرة الإسكان:

ظاهرة الإسكان منسوبة لأسد، وشائعة في شعرهم، فقد جاء إسكان واو ضمرانير المذكر "هو" في شعر الحسن بن مطِر ، يقول:

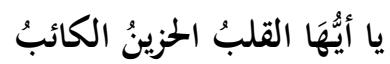

بانَ الشبابُ والشبابُ ذاهِبُ

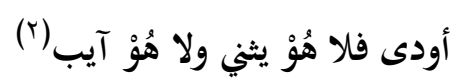

وأما إسكان الياء من "هي" فقد جاء في شعر عبيد بن الأبرص، يقول:

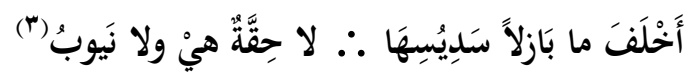

وقوله أيضًا:

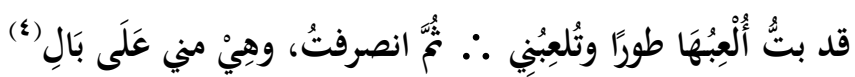

1- من الرمل، ولم أقف على قائله، ينظر البيت في: شرح شواهد الإيضـاح لابن بري:

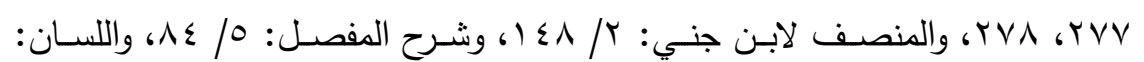

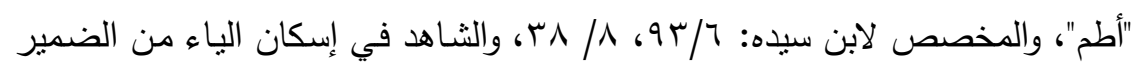

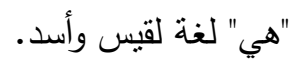

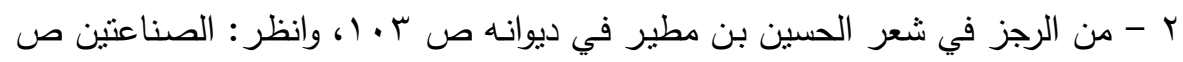

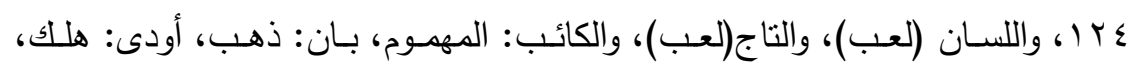

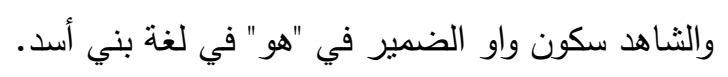

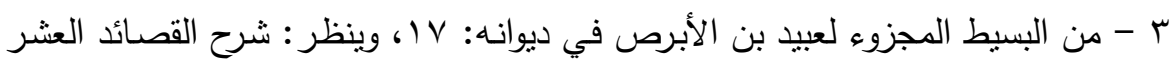

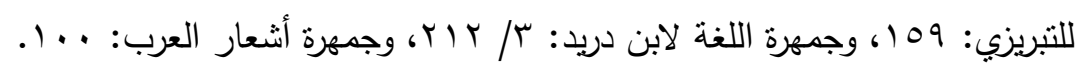

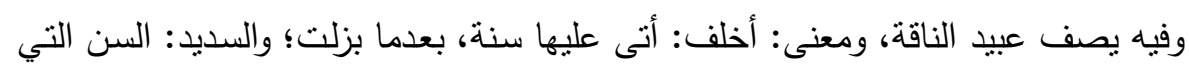

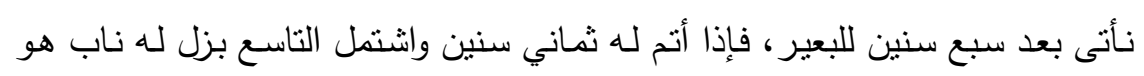
آخر أسنانه.

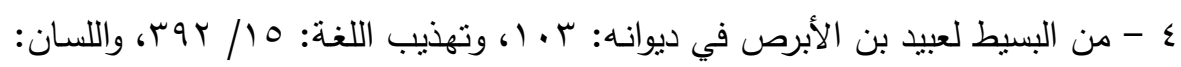

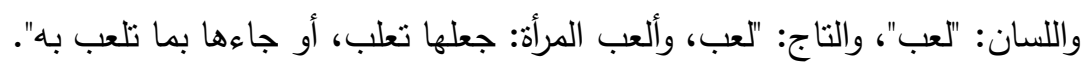




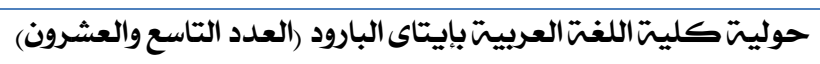

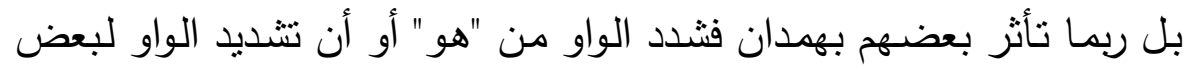
بطونهم، وهذا واضح في شعر الكميت، وذللك في قوله:

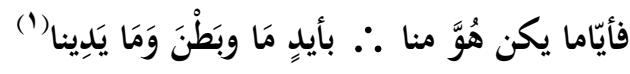

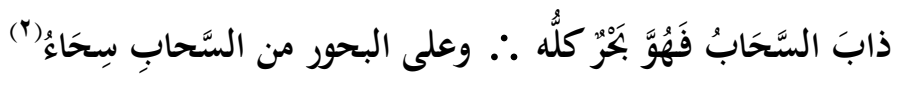

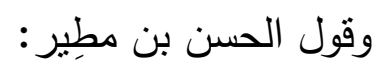

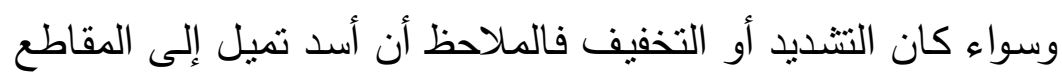

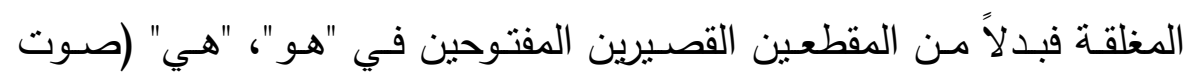
ساكن + لين قصير ) قالوا: هُوْ ، وهيْ بمقطع واحد مغلق متوسط مـع الإسكان (صوت ساكن + لين قصير +صوت ساكن)، وفي "هوّ" أبدلوا المقطع القصبر هون المفتوح الأول بمقطع مغلق "هُوْ /وَ". الأول: صوت ساكن + لين قصير + صوت ساكن، والثاني: صوت ساكن + لين قصير $\{\hat{1}\} \hat{0}$

ا - من الوافر للكميت في هاثمياته ص 99 ب، وأساس البلاغة "يدي"، واللسان: "يدي"،

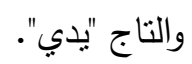
r - من الكامل للحسين بن مطير في ديوانه ص م، الثعر والثعراء: . 9. 


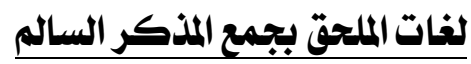

وردت في اللغة ألفاظ جمعت جمع مذكر سالما مع أنها فقدت شرطًا

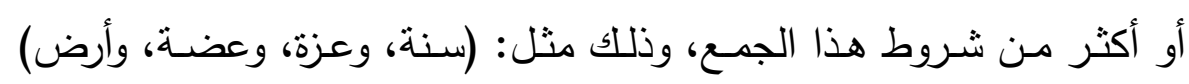

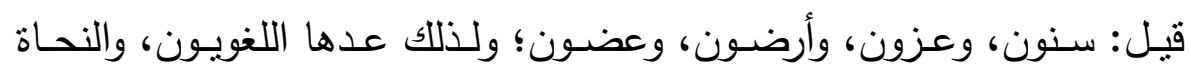
ملحقة بجمع المذكر السالم، وفي هذا الملحق لغات وهي ما يأتي:

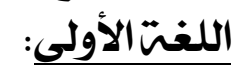

أن يعـرب إعـراب جــع المـذكر السـالم فيرفـع بـالواو وينصـب ويجـر باليـاء، وهذه لغـة الحجازيين، وعليـا قيس، تقول: هذه سـنون، وأتيت سنين، وعجبت من سنين ('). بوهاءه وهده وعلى هذه اللغة ورد الحديث النبوي الثريف في إحدى رواياته: "واجعلها عليهم

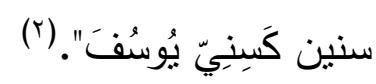
اللغتش الثانيـتي أن يلزم هذا النـوع مـن الألفاظ؛ اليـاء في الأحسوال الثناثـة ويعرب بحركات ظاهرة على النون، ونسبت هذه اللغة لبني أسد وتميم وبني عامر . قال الفراء: ومن العرب من يجعلها بالياء على كل حال، ويعرب نونها، فيقول:

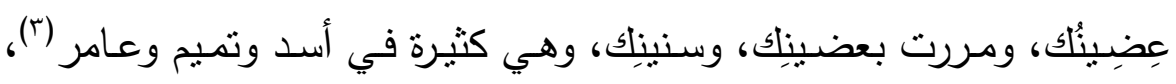
وعليها قول الثناعر:

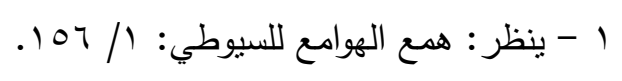

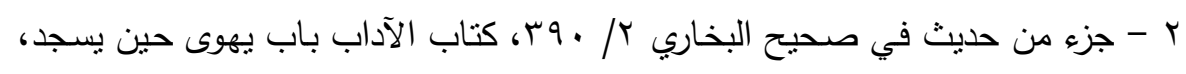

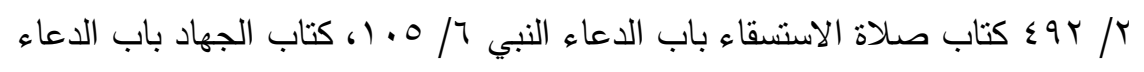

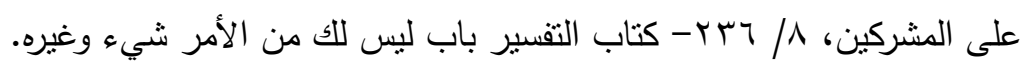

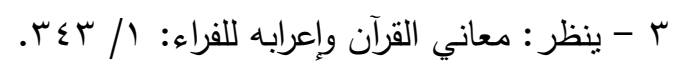




\section{حوليتة كليت اللغتا العربيتبايتاى البارود (العدد التاسع والعشرون)}

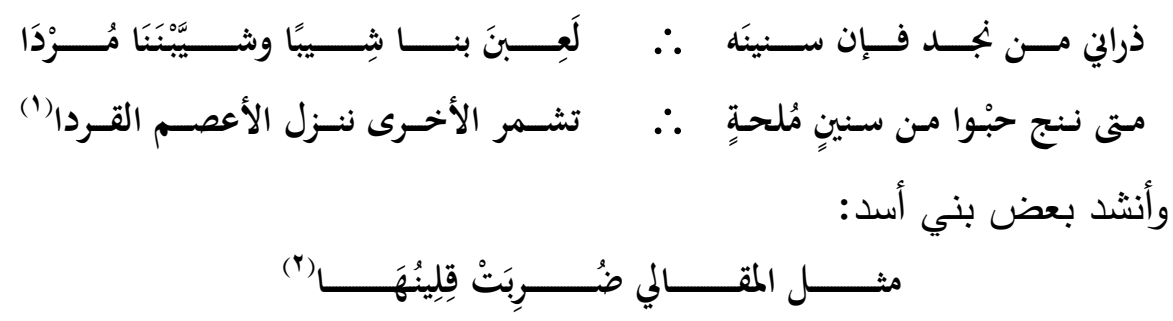

وذكر ابن فارس: أن هذا الضرب في الجمع قد كثر، ولو جعل قياسًا مستمرًا، كان مذهبًا، لكن ابن جني عد ذللك ضرورة شعرية.

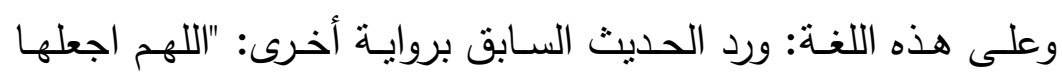
عليهح سنينًا كسنين يوسف" هذه وهذه اللغة أجيزت في الجمع نفسه أيضـا كما تقول: هؤلاء مسلمونُ، كما قال الثاعر :

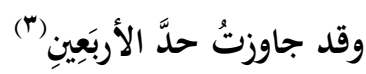
وماذا يَدَّرِي الشعراءُ مني

1 - البيتان من الطويل للصمة بن عبد الله القسيري، ونسبهما الزمخشريّ في المفصل:

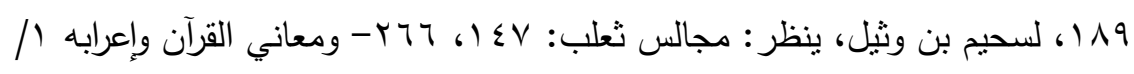

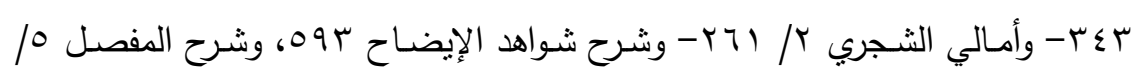

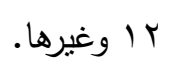

والثـاهد "فإن سنينه"، "من سنين" حيث أعرب اللفظ بالحركات على النون، فنصبه

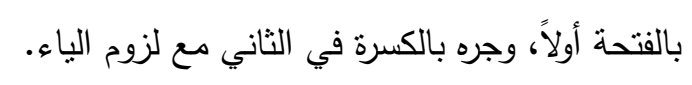

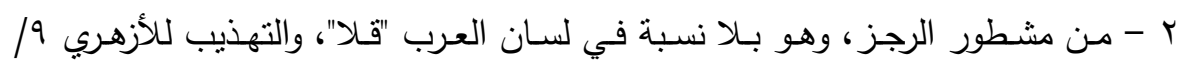

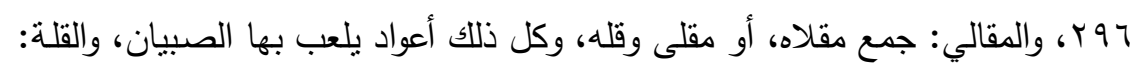

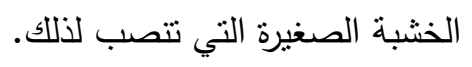
والثاهد في قوله: (قلينُها) حيث أعرب بالحركات الظاهرة مع لزوم الياء، ورفعه بالضمة.

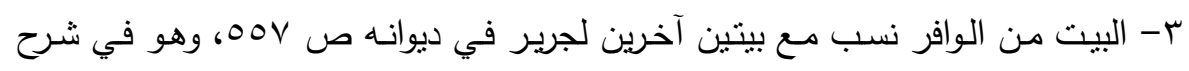

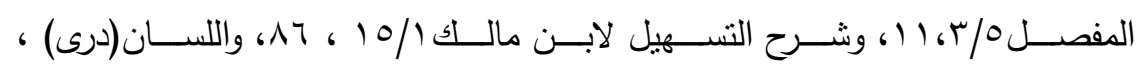

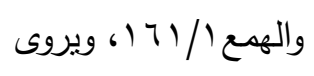
والثـاهد: "حد الأربعين" حيث أعرب الأربعين بالحركات الظاهرة على النون مـع لزوم الياء مجرورة بالكسرة. 
لزوم الإعراب بالحركات الثناث على النون مـع التتوين، فتقول: هذه

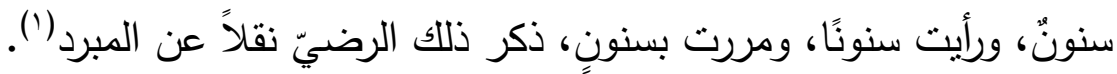
اللغتم الرابعتص: ورابت:

لزوم الواو أيضًا، وفتح النون مطلقًا، ويعرب اللفظ حين إذن بحركات

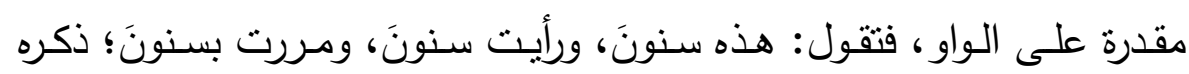

الثيخ خالد الأزهري نقلاً عن السيرافي (r).

\section{والذي يهم البحث من هذه اللغات، الأولى والثانية لما يأتي:}

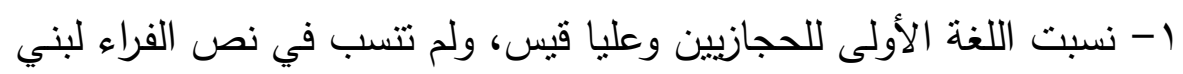

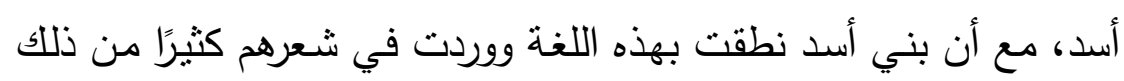
قول نافع بن نفيع الفقعسي:

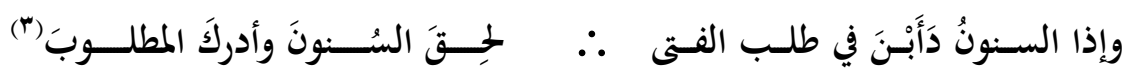
وقول عبيد بن الأبرص:

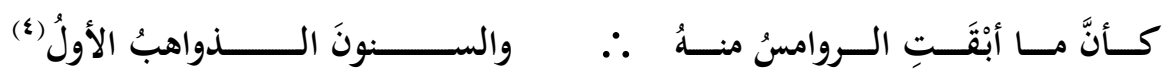
وقول بشر بن أبي خازم:

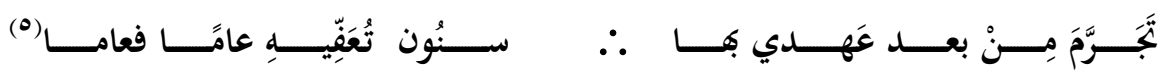

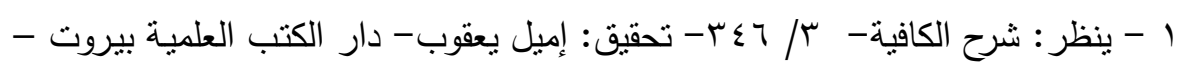

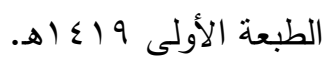

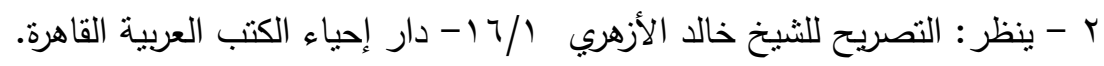

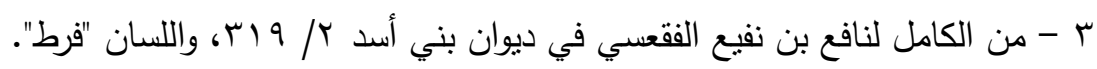

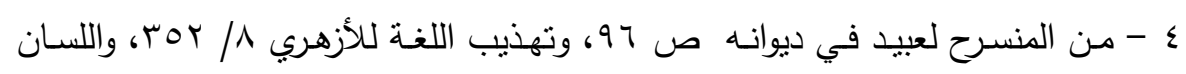

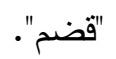

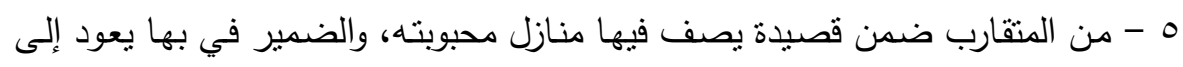

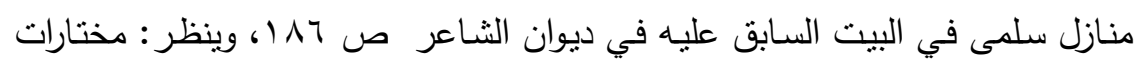

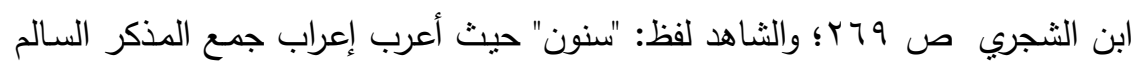

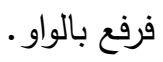




\section{ملامح التزكيب والبنية في لغة بنى أسد في ضوء الشواهد الشعرية}

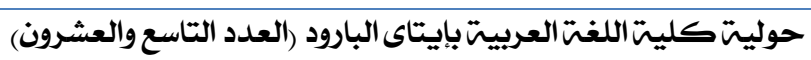

وفي قول الكميت بن يزيد:

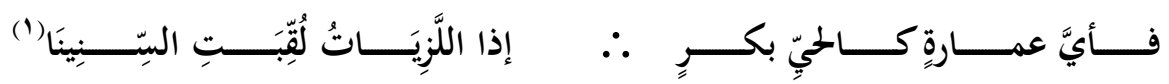

وفي لفظ "عزين" جاء قول عمرو بن شاس:

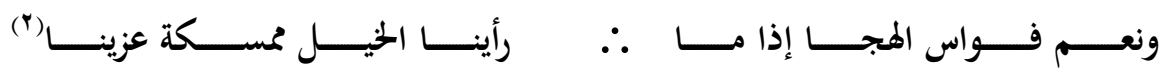

وقول الكميت:

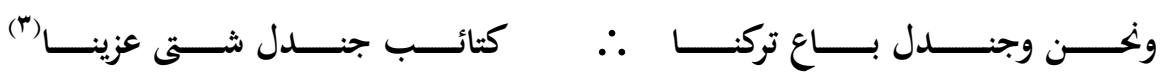

وفي لفظ "أرضين" جمع أرض جاء قول عبيد ابن الأبرص:

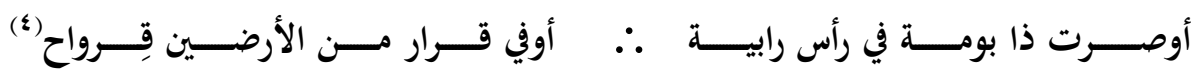

وغير ذلك مـن كلمـات جـاءت ملحقـة بجمـع المذكر السـالم، ومعربـة

بإعرابه فهذا يدل على أن أسد نطقت بهذه اللغة كثيرًا، ومن المحتمل أن يكون ما جاء من شعر شعرائهم على هذه اللغة رغبة منهم في محاكاة اللغة الأجود،

وتخلصًا من لهجتهم الخاصة حيث لا ضرورة تدفعهم إلى النطق بهاء

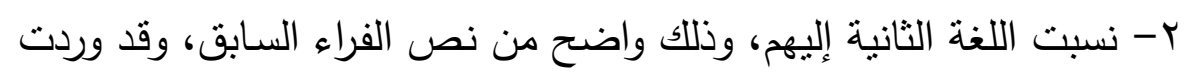

في شعرهم، وهذا واضح من قولهم السابق، وأنشد بعض بني نئ أسد:

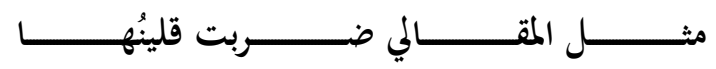

وهذا الرجز استشهذ به علماء اللغة في كتبهر كثيرًا.

وفيه أن تلزم الياء في الأحوال الثناثة وتعرب بحركات ظاهرة على النون.

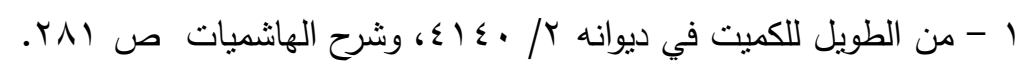

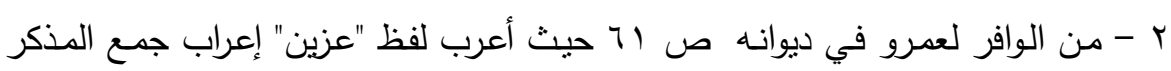

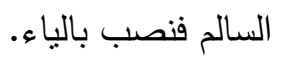

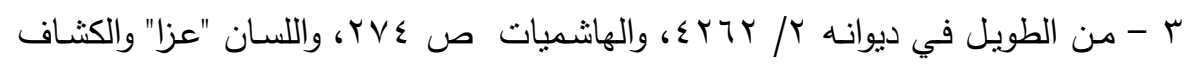

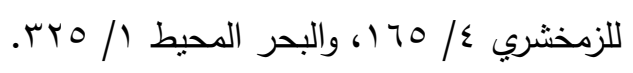

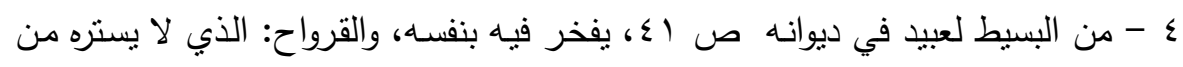

السماء شيء. 
ملامح التركيب والبنية فل لغة بنى أسد في ضوء الشواهد الشعرية

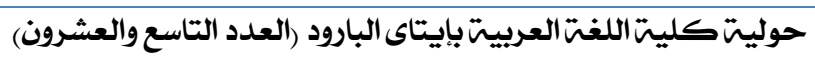

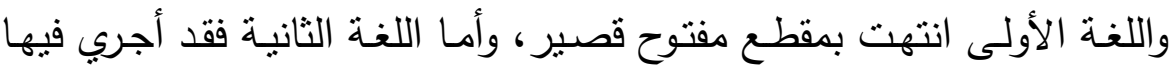

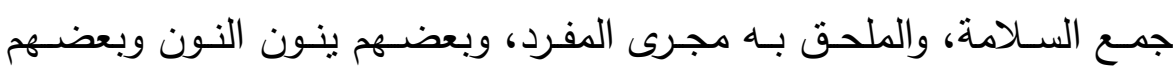
لاينونها، كما سبق في الأمنلة.

فإذا لم تتون انتهت بمقطع قصير مفتوح كالأولى، وإن نونت انتهت بمقطع مغلق.

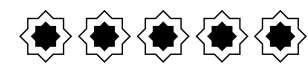




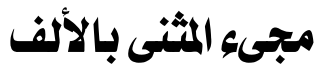

\section{في الأحوال الإعرابية المختيلة}

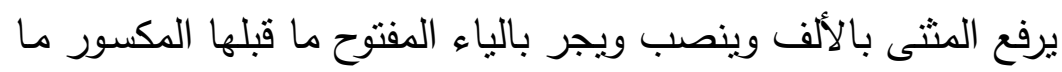

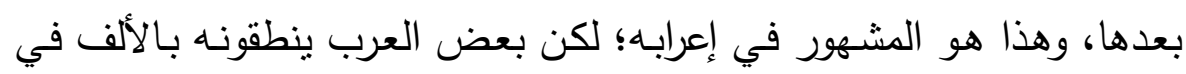

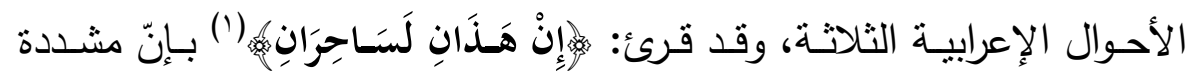

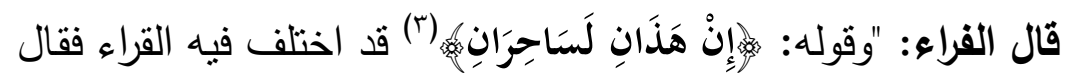
بعضـهم: هو لحن، ولكننـا نمضـي عليه لئلا نخـالف الكتاب - فقراءتتـا "إنّ" بـالألف- على لغـة بنـي الحسارث بـن كعـب يجعلـون الاثتين في نصـبهما وخفضهها بالألف (๕). وقال الأخفش: ونقرؤها ثقيلة أي: "إنّ"، وهي لغـة لبني الحارث بن كعب، وقال ابن جني: من العرب من لا يخاف اللبس ... فيدع الألف ثابتة

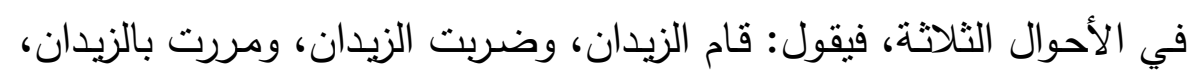
وهم بنو الحاث بن كعب وبطن من ربيعة(0)؛ وكذا ذكر ابن يعيش (؟) وغيره.

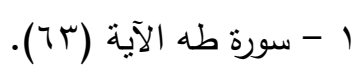

r - وقد قرأ بذلك نافع وابن عامر وحمزة والكسائيّ وطلحة بن مصرف، كما قرأ بها أبو

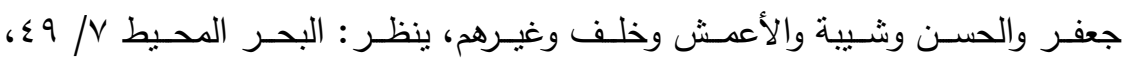

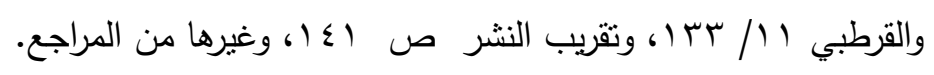

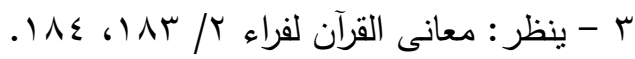

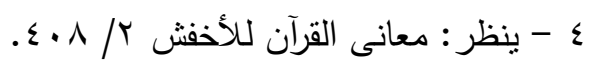

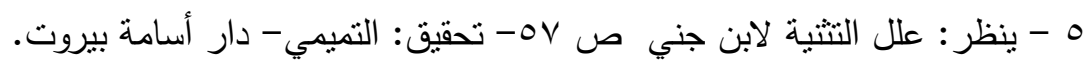

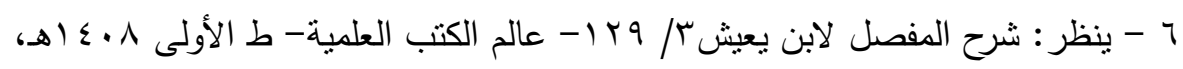

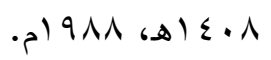


عزيت اللغـة لبنـي الحـارث بـن كعب في معظم أقوال العلمـاء، كمـا عزيت لبطن من ربيعة(') وختُعم وزيد (r)، وغيرهم. قال السيوطي: ولزوم الألف في الأحوال الثالثة معروفة عزيت لكنية ولكنانة، وبني الحارث بن كعب، وبني العنبر، وبني الهجيم، وبطن من ربيعة، وبكر

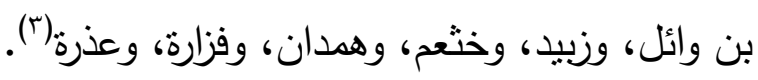
الشواهد عليها: جاء على هذه اللغة غير القراءة السابقة قول النبي سلى الله عليه

$$
\text { وسلم-: "لا وتران في ليلة"(๕). }
$$

كما جاء عليها عدد من الثواهد الثعرية التي استشهد بها العلماء لإثباتها؛ من ذلك مـا جـاء في قول الفراء، وأنشـني رجل مـن بنـي أسد عنهم يربد بني الحارث بن كعب:

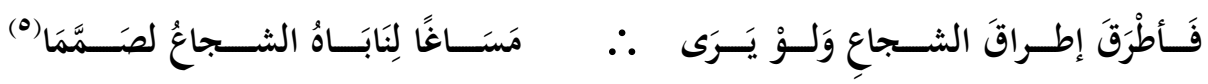

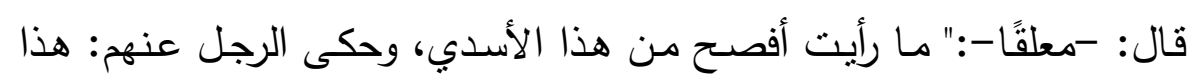

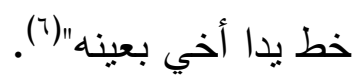

1 - ينظر : علل التثية ص VV.

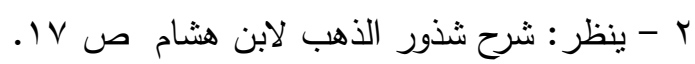

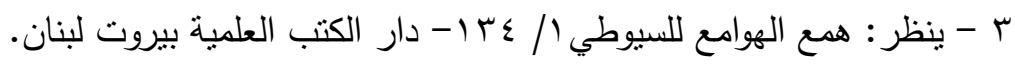

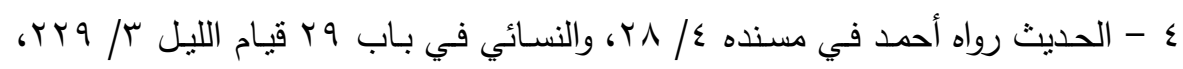
.

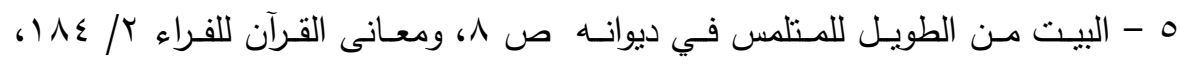

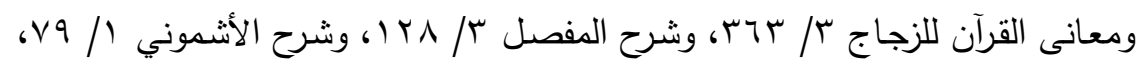

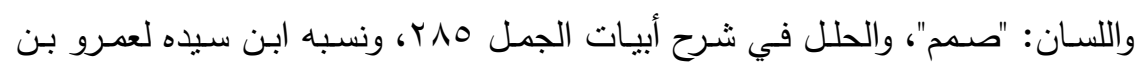

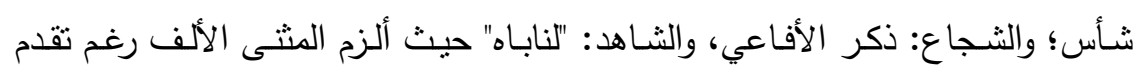
حرف الجر عليه.

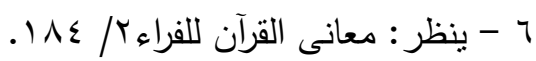




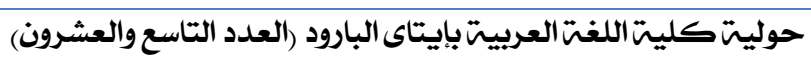

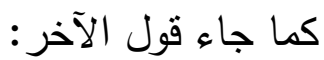

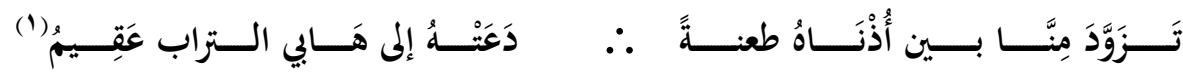

وجاء أيضًا:

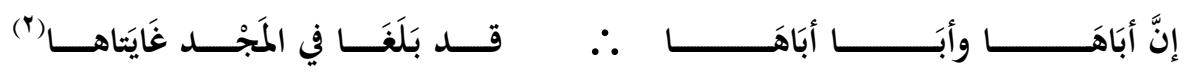

\section{موقف بني أسلد من هذه اللغة:}

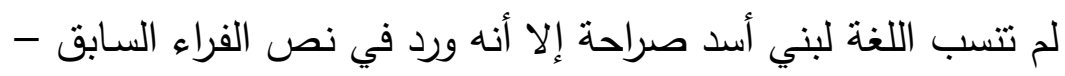

وأنشدني رجل من بني أسد عنهم يريد بني الحارث .... ثم قال: مـا رأيت

أفصـح من هذا الأسدي، وحكى الرجل عنهم: هذا خط يدا أخي بعينه، فهل

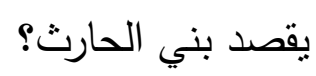

والبيت الثـعري: فأطرق .... البيت، رواه بعض العلمـاء لعمـرو بن

شأس وهو من بني أسد.

وبالعودة إلى أشعارهم نجد الظاهرة واضحة وضوح العيان، فقد جاء في شعر

سبرة بن عمرو الأسدي:

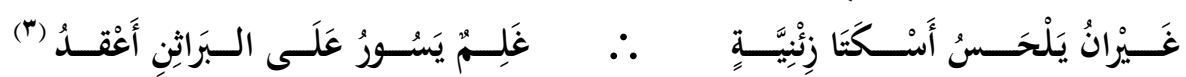

ا - من الطويل لهوير الحارثي في مشكل إعراب القرآن لمكي r / 97، وشرح المفصل

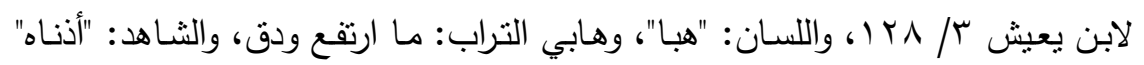

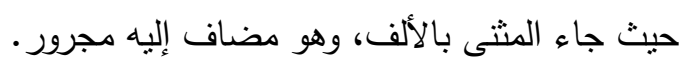

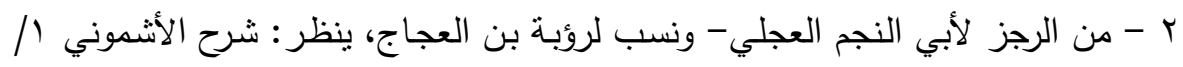
• V، والتصريح / / / 7 ك، والثاهد: "غايتاها".

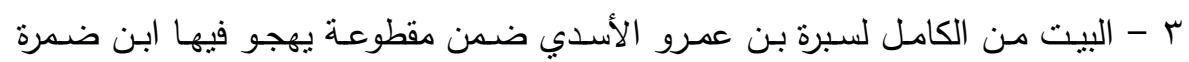
النشلي وله رواية أخرى هي: (اسكتي زئنية...) وعليها فلا شاهد.

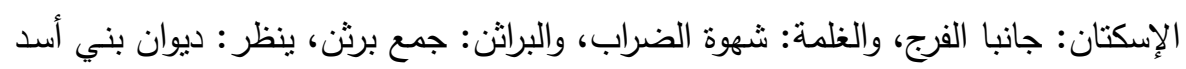

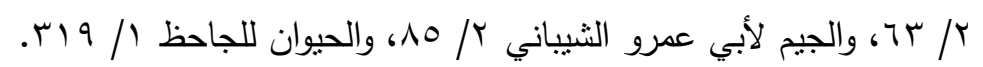




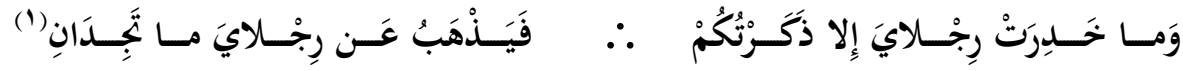
فلفظ: "أسكتا" في البيت الأول جاء بالألف مع أنه مثنى منصوب، لأنه مفعول

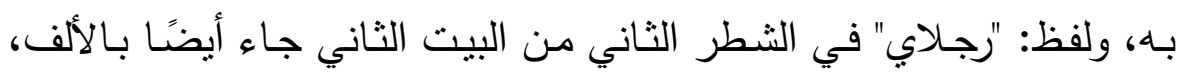
وهو مثنى مجرور ب"عن". فهذا يال دلالة واضحة على أن الظاهرة موجودة عند بني أسد، وأنهم لهجوا بها، وكان ذلك على الأقل لبعض بطونهم، كما يظهر أيضًا أنهم كانوا لا يميلون إلى نيابة الحروف عن الحركات ففي الملحق بجمع المذكر السالم نسب إليهم أنهم ألزمـوه الياء في الأحوال الثلاثة، وكان الإعراب بحركات ظـاهرة على النون وهنـا ألزموا المنتى الألف وكان الإعراب بحركات مقدرة عليها.

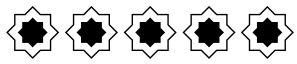

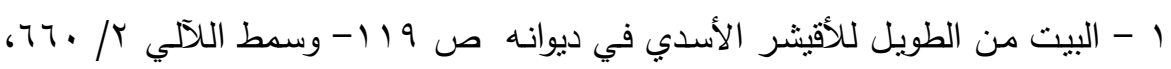
والخذر : امذلال يغشى الأعضاء. 


\section{حوليتّ كليت اللغت العربيتبايتاى البارود (العدد التاسع والعشرون) \\ إسناد الفعل وشبهه \\ إلى فاعل ظاهر}

إذا أســند الفعـل أو شـبهه إلى فاعـل ظـاهر مثثىى، أو مجمـوع فـإن جمهور العرب لا تلحق بهذا الفعل، أو ما يجري مجراه علامة تثتية، ولا جمع، فتقول: قام أخواك، وقام إخونتك.

لكن بعض العرب يطابقون بين الفعل وفاعله، وهو الاسم الظـاهر ،

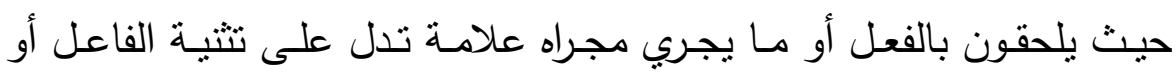

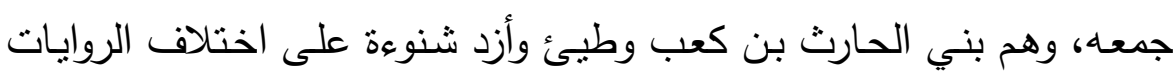
التي رواها العلماء(').

وقد خـرج على هذه اللغـة: بعض القراءات القرآنيـة من ذلك قراءة

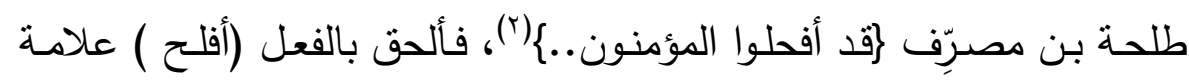

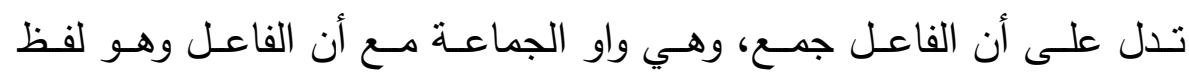

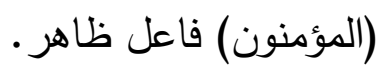

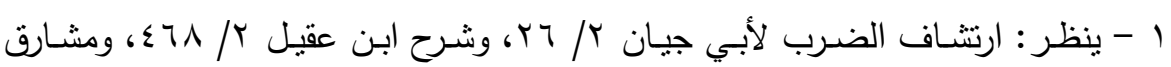

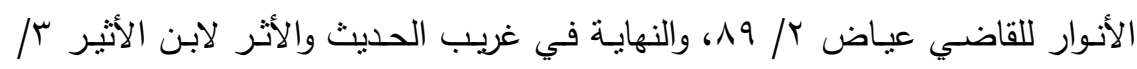

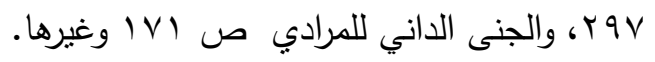

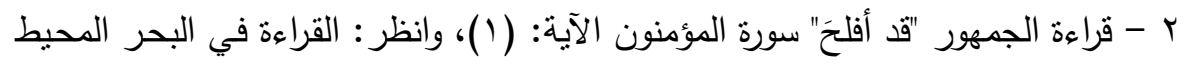

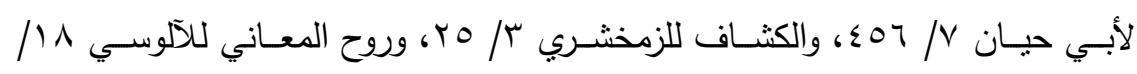

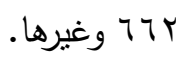




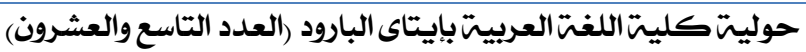

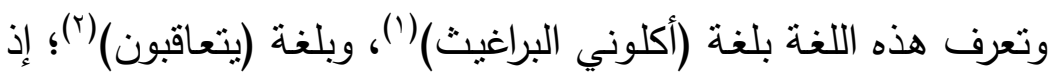

جاء عليها الحديث الثريف الذي اشتهر في الاستشهاد به على تلك اللغة وهو

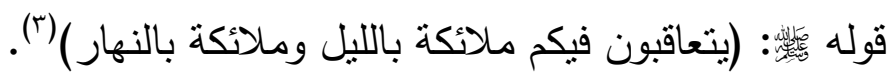

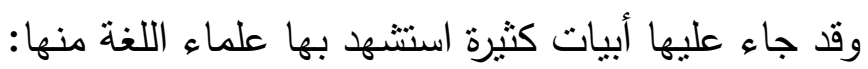

قول عبد الله بن قيس الرقيات:

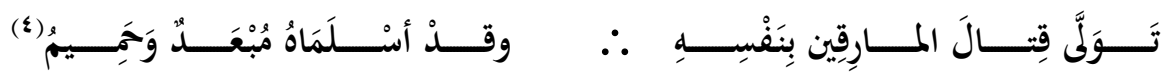

وقول أمية ابن أبى الصلت:

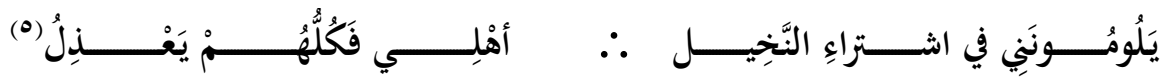

وقول أبي عبد الرحمن العتبي:

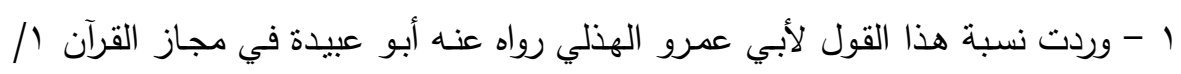

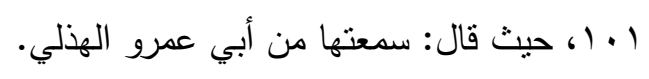

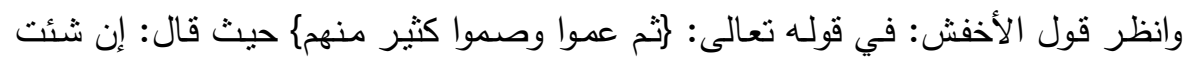

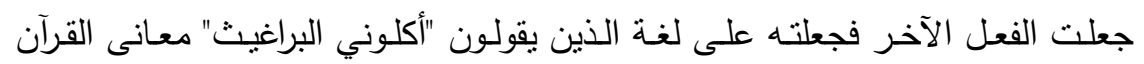

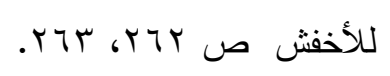

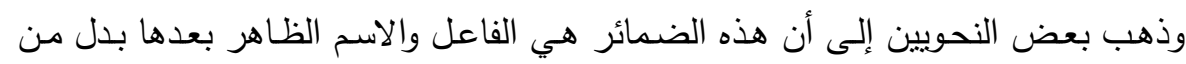

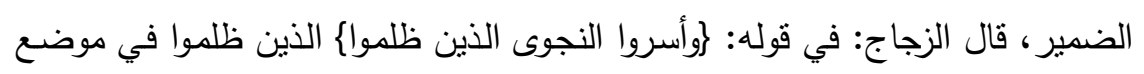

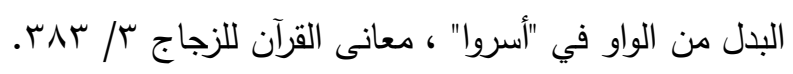

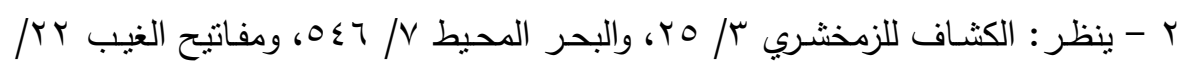

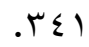

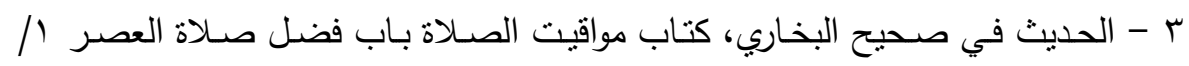

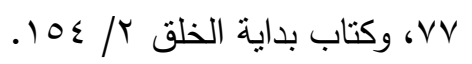

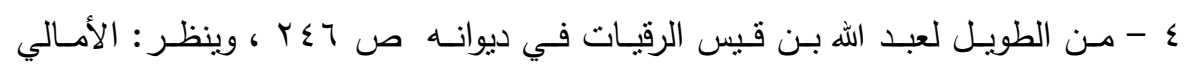

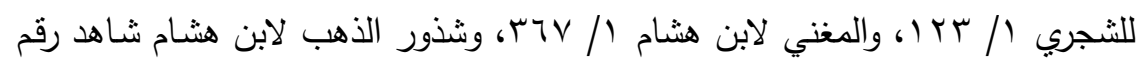

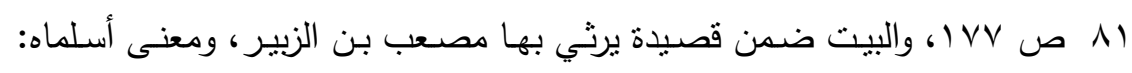
خذلاه.

ه - من المتقارب لأمية بن أبى الصلت في الأمالي الثجرية / / سبا ، وأوضح المسالك

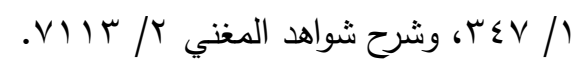




\section{حوليت كليت اللغت العربيتبايتاى البارود (العدد التاسع والعشرون)}

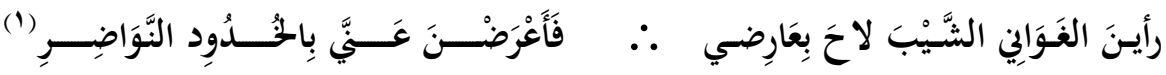

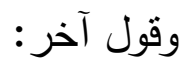

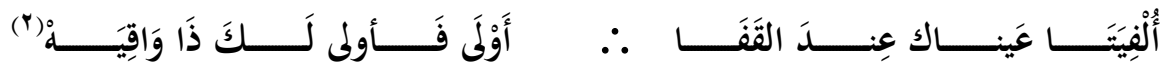
وغير ذلك من أبيات.

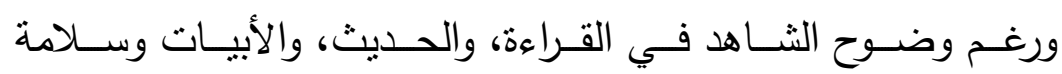

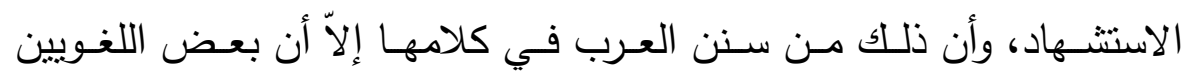
يتعسفون في التأوبل فيخرجونها على التفسبر والإبهام، وذللك مثل تخريجهم

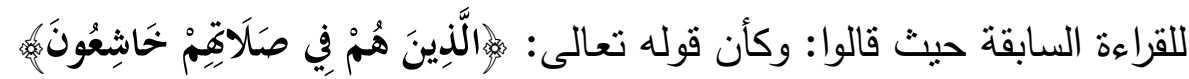
الآية تفسير لما أبهم في قوله: (قد أفلحوا..._(r). موقف شعراي بني أسد من الظاهرة: لـم أجد فيمـا ذكر مـن الرواة عزورًا لبنـي أسـد أو شـاهدًا ينسـب إلى منى

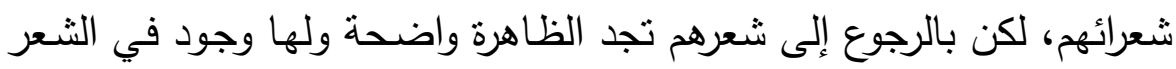

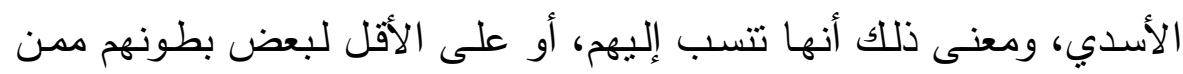
جاوروا من نسبت إليهم وهم بني الحارث بن كعب، وطيئ، وشنوءة ومن ذللك

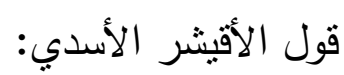

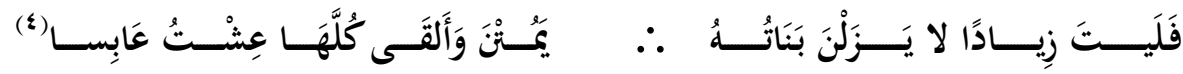

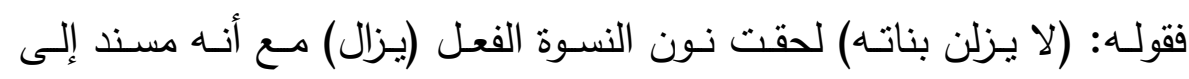
(بنات)، وهو فاعل ظاهر ، وذلك للالالة على أن الفاعل جمع مؤنث.

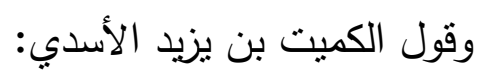

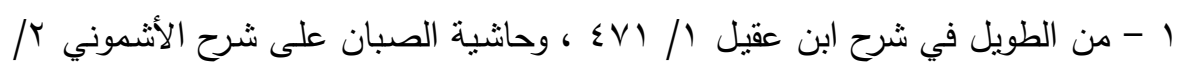
. $\leqslant \vee$

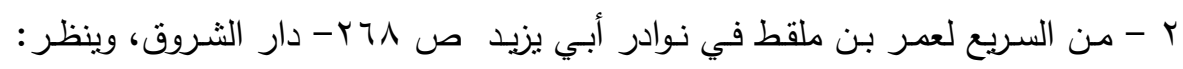

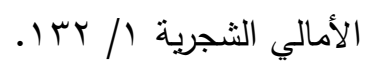

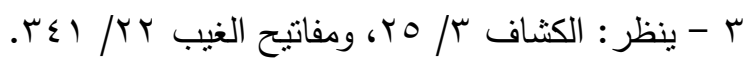

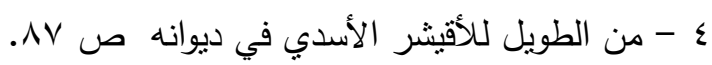




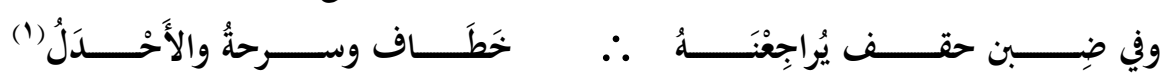
فعلى لغة الجمهور كان ينبغي أن يقول (براجعه) خَطَاف، وسرحةُ، والأحدل وهي أسماء كلاب- فلحق الفعل نون النسوة على لغة "أكلوني البراغيث". ومن إجراء اسم الفاعل العامل مجرى فعله جاء قول بشر بن أبي خازم على ألى لئل هذه اللغة أيضًا:

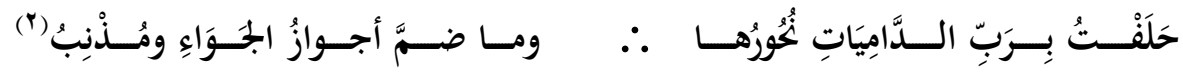
فقوله: (الداميات نحورها) جاء على هذه اللغة ولو جاء على اللغة المشهورة لقال: (الدامية نحورها).

ولا يخفى على دارس الصـوتبات زيادة مقطع في بعض الكلمات التي لحقها الضمير الدال، أو استبدل مقطع منها بآخر أطول منه، فمثناً:

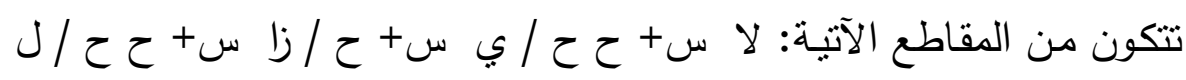

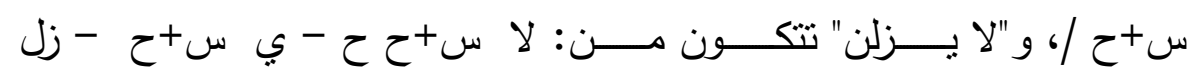
س+ح+س ن س سج؛ فالمقطع الثالث في الأولى مفتوح منوسط، وفي الثانية مغلق متوسط.

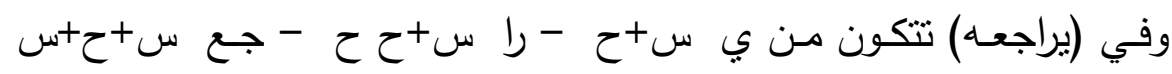

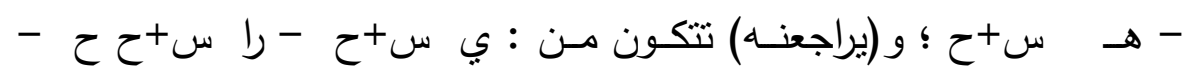

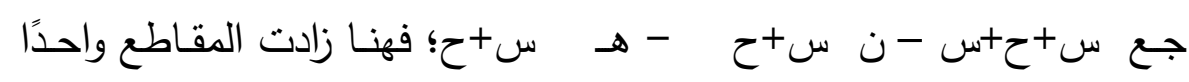

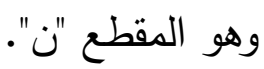

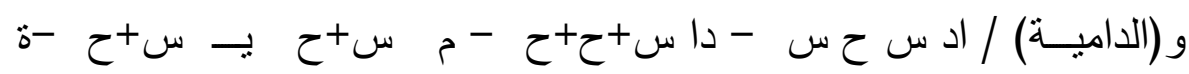
$\cdot \tau^{+}$

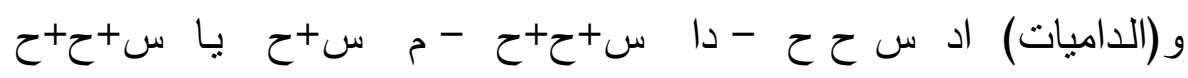

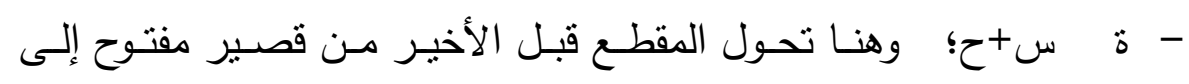

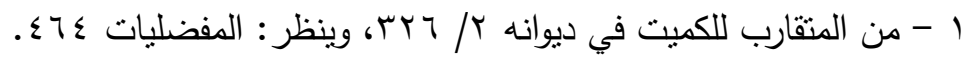

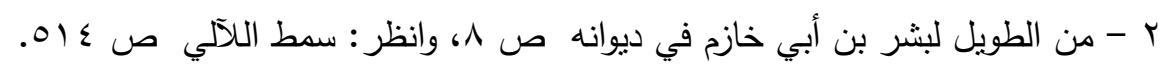


متوسط مفتوح، وتغير المقاطع واختلاف نوعها أو عددها يـؤثر في انتقال

\section{حذف نون (منز) الجارة}

من حروف الجر "من" ونونها ساكنة، وتفتح إذا وليها ساكن، لكنه قد

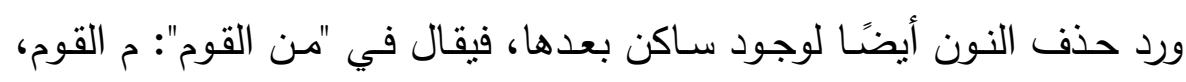
واسنتهد النحاة واللغويون على ذلك بقول الثاعر:

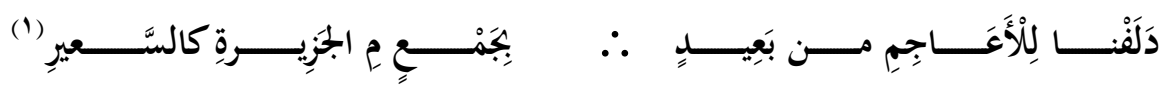
فقوله: (م الجزيرة) فيه حذف لنون "من" لسكونها وسكون اللام بعدها. وقد ذكر ابن الثجري: أن ذلك تتبيهًا للنون الساكنة بحروف اللين، لأن فيها غنة تضارع ما فيهن من المد واللين(؟).

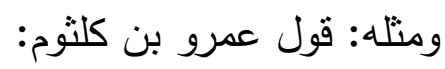

سوى حِذْم أَذْواد محَذَّفَة النَّسل (َ)

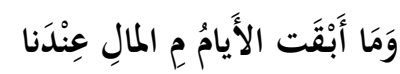
وقول الآخر :

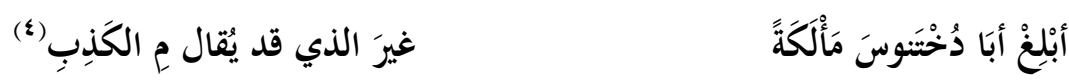
فقد حذفت نون "من" الجارة، والأصل في البيت الأول: (من المال) وفي البيت الثاني: (من الكذب).

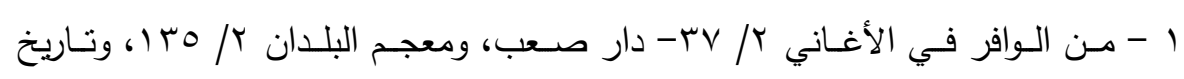

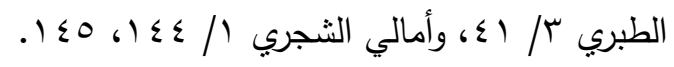

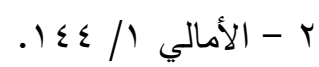

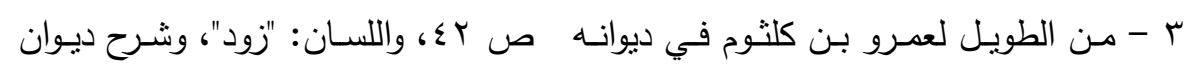

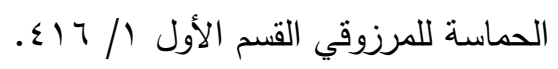

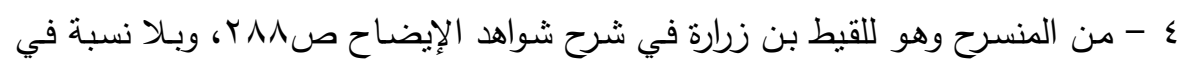

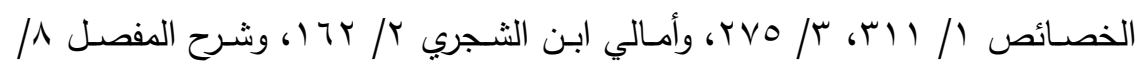

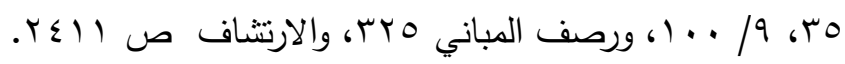




\section{حوليتّ كليت اللغت العربيت بايتاى البارود (العدد التاسع والعشرون)}

وذكر ابن يعيش أن الحذف للتخفيف، وليس لالتقاء الساكنين، حيث

قال: وقد حذفوها لا لالتقاء الساكنين بل لضرب من التخفيف (').

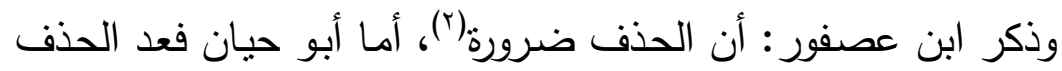

جائز في سعة الكلام مع اللام المظهرة، وليس مخصوصًا بالضرورة."(َ). وأما العيني، فأورد قول الثـاعر:

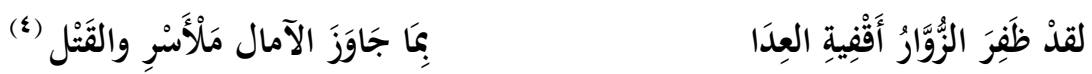

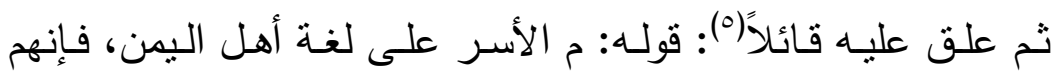

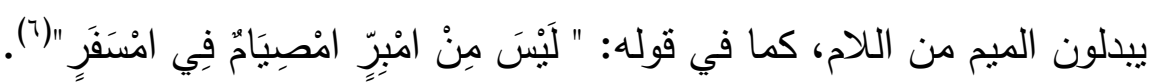

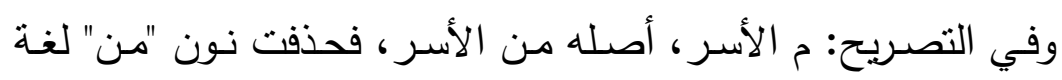

زبيد وختُعم من قبائل اليمن (V)

وواضح من السابق أن الحذف لغة لبعض العرب من أهل اليمن، وقد وجاءت الظاهرة في شعر أسد على لسان شاعرهم عبيد بن الأبرص، في قوله:

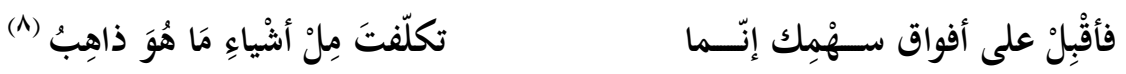
وقوله:

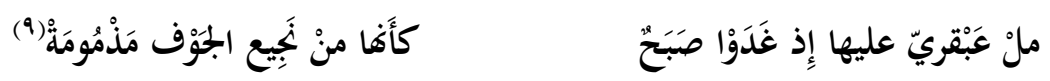

\section{$\{\hat{1}\} \hat{0}$}

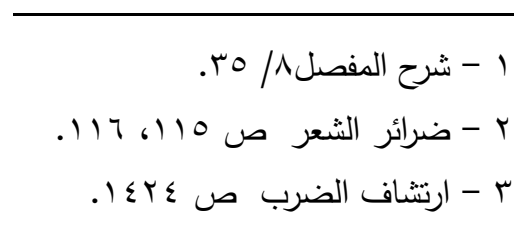

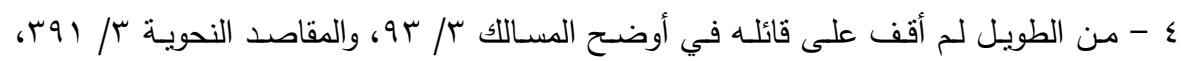

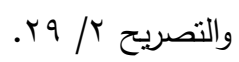

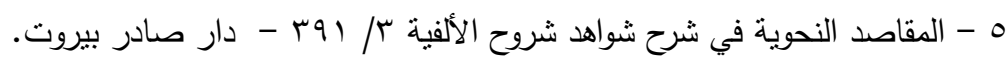

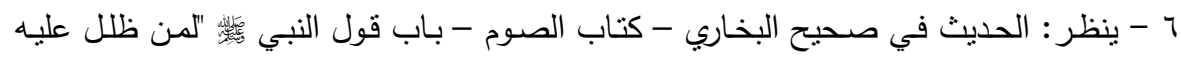

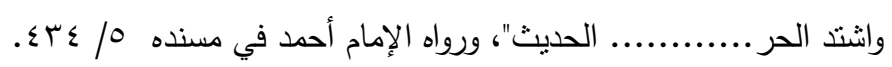

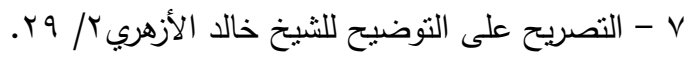

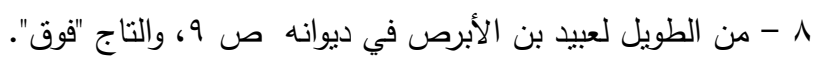

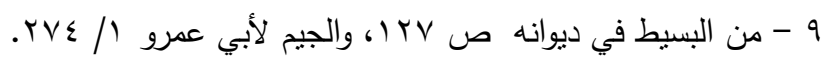




\section{حذف اللام والألثف \\ من: (على) الجارة}

من حروف الجر "على" وهو حرف ثناثي يتكون من: العين واللام

والألف، وذللك في وضـع اللغـة، إلاّ أن ألفهـ تحذف نطقًا لا كتابـة إذا وليها ساكن حتى لا يلتقي ساكنان فيما هو كالكلمة الواحدة وذللك نحو : "دخلتُ على ودى ولى

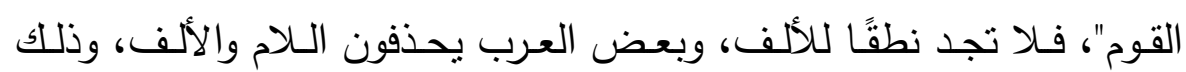
تشبيهًا بقولهم: "بلحارث، وبلعنبر" في: "بنى الحارث، وبنى العنبر".

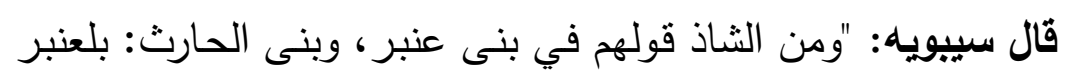
وبلحارث، بحذف النون، وكذلك يفعلون بكل قبيلة تظهر فيها لام المعرفة؛ فأما

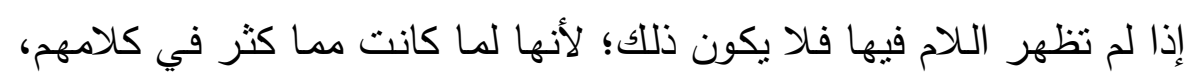
وكانت اللام والنون قريبتي المخارج حذفوها وشبهوها بـ"مست" لأنهما حرفان

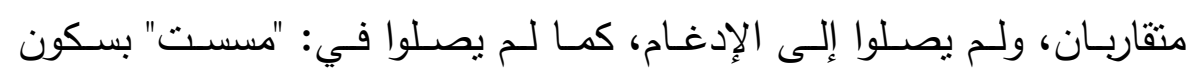

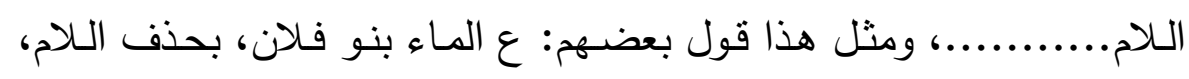

يريدون على الماء بنو فلان، وهي عربية"('). فتلاحظ في كلام سيبويه الآتي:

ا - أنه ذكر حذف النون من نحو "بنى العنبر ، وبنى الحارث" لمـا لـ

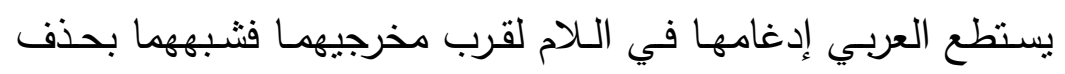
إحدى السينين في نحو "مسست" فقالوا: "مست" واللامين في نحو: "ظللت" والنونين في : "ظننت" فقالوا: "ظلت، وظنت وغئ وغيره، وسيأني الحديث عن ذلك فيما يتعلق بالمثلين. ץ- أن الحذف يحدث إذا كانت لام التعريف ظاهرة غير مدغمة، وتظهر بالفئ

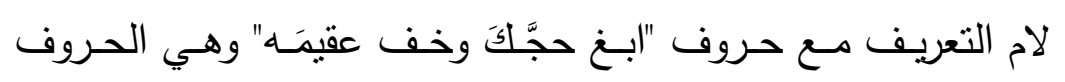

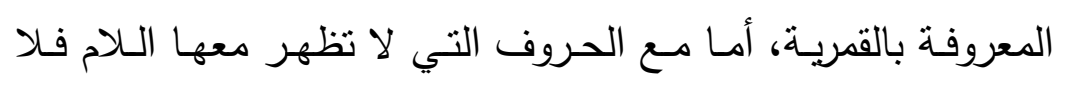




\section{حوليتّ كليتا اللغت العربيتبايتاى البارود (العدد التاسع والعشرون)}

تحذف النون مثل بنى النجار وبنى النمير، وهى الحروف المعروفة

$$
\text { بالحروف الثمسية. }
$$

ץ- أن ما ينطبق على النون مع لام التعريف المظهرة، ينطبق أيضًا على لـى

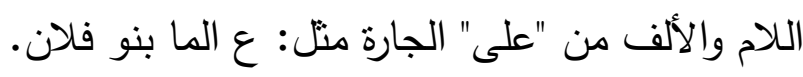

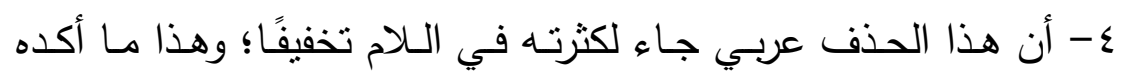

المبرد حيث قال('): "ومما حذف استخفافًا لأن ما ظهر دليل عليه

قولهم في كل قبيلة تظهر فيها لام التعريف مثل: "بنى الحارث وبنى

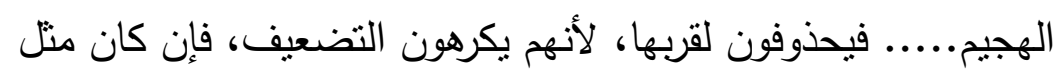
بنى النجار وبنى النمير .... لـ يحذفوا، لـئلا يجمعوا عليه علتين:

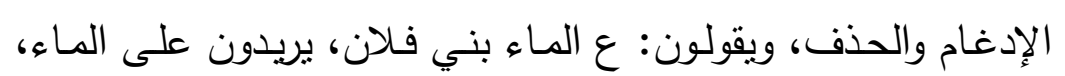

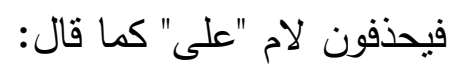

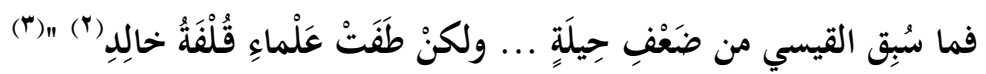

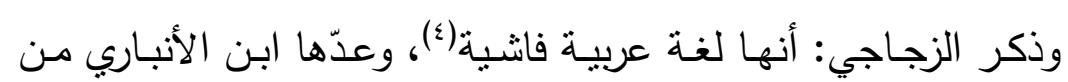

الثاذ الذي لا يقاس عليه، وإنما وقع في كلامهم لكثرة الاستعمال(ث).

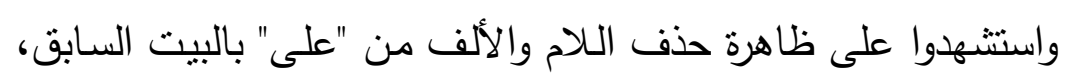
كما استشهدوا أيضًا بقول الآخر:

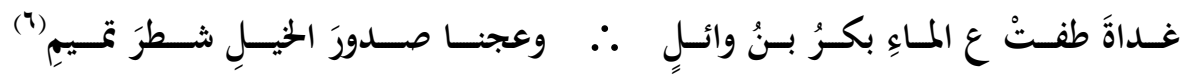

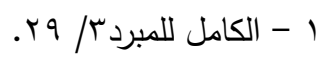

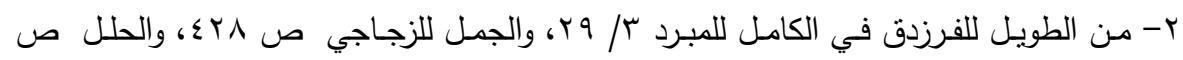

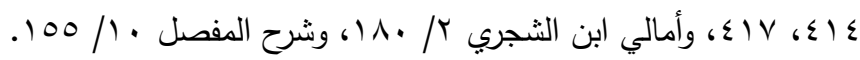

$$
\begin{aligned}
& \text { r- الكامل للمبرد }
\end{aligned}
$$

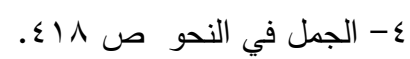

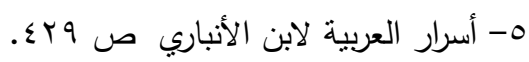

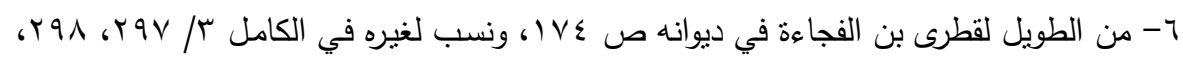

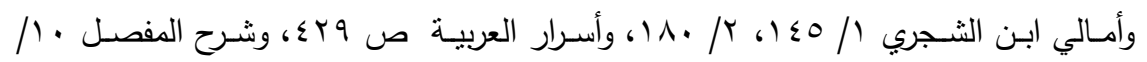




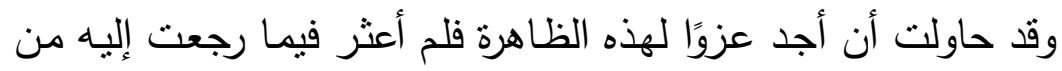

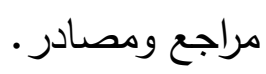

وذكرت الباحثة/ صـالحة راشد: أن هذا من خصائص القبائل البدوية

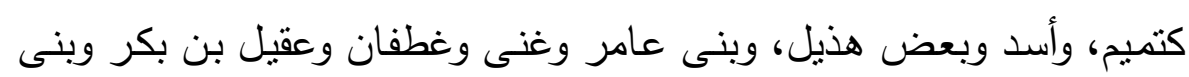

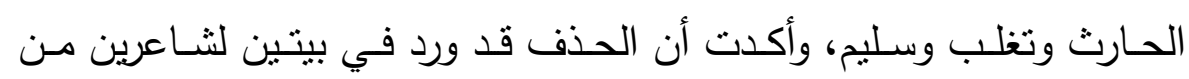

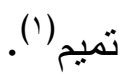

ويقوي ما ذهبت إليه من أن الظاهرة لهذه القبائل المتجاورة كتميم وأسد

مجئ ذلك في قول أبى السمال الأسدي:

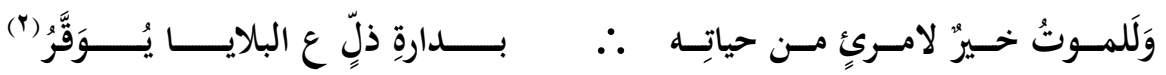

فسقطت اللام والألف من "على".

وهذا يتفق مـع طـابع القبائل البدويـة حيث الميل إلى التخفيف والسـرعة في

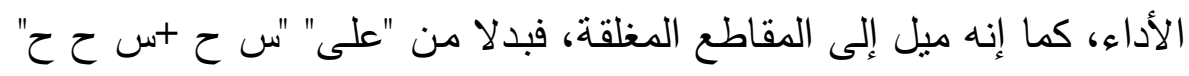

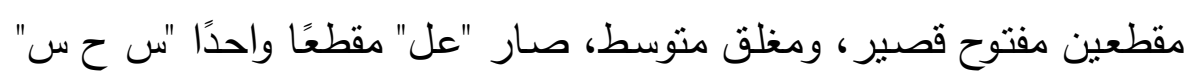
مغلقًا منوسطًا.

\section{$\{\hat{1}\} \hat{0}\}$}

1- ينظر : اللهجات في كتاب سيبويه أصوانًا وبنية لصسالحة راثد حسين ص 00V، 


\section{أو ظاهرة القطعة}

الترخيم: هو حذف آخر الاسم في النداء نحو: يا حار في يا حارث، ويا مال في يا مالك ... وغير ذلك.

ويقع الحذف لبعض الكلمات في نطق بعض القبائل في غير النداء،

وقد اختلف العلماء حوله باعتباره ترخيمًا في غير النداء وليس بترخيم. فذهب المبرد: إلى أنه لايجوز ترخيم غير المنـادى في الضـرورة إلا ناء

على لغة من لا ينتظر ('). وذهب سيبويه وجمهور النحويين إلى أنه يجوز للشاعر إذا اضطر أن لإنهر

يرخم غير المنادى على اللغتين: لغة من ينتظر ولغة من لا ينتظر (؟).

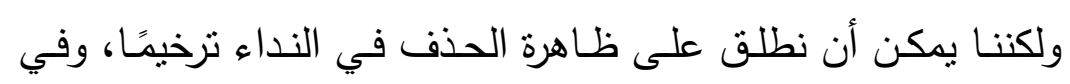

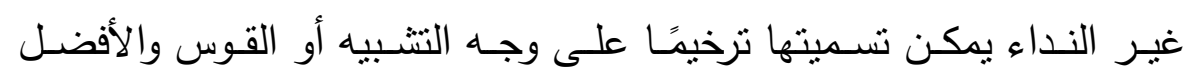
تسميتها بالقطعة، وهي ظاهرة معروفة لطيئ، وهي قطع اللفظ قبل تمامه.

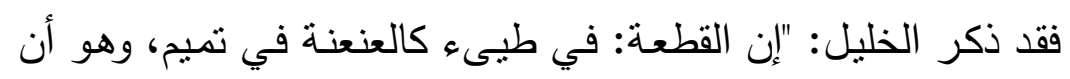
يقول: يـا أبـا الحكا وهو يريد: يـا أبـا الحكم، فيقطع كلامـه عن إبـان مـا بقية

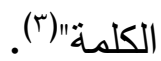
وقد جـاء ذلك القطع في النداء فوافق الترخيم في شـعر أبسى حاتم الطائي، حيث قال:

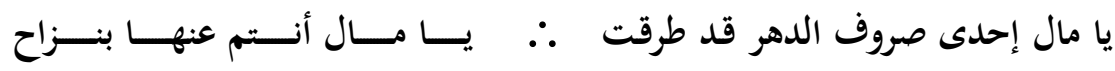

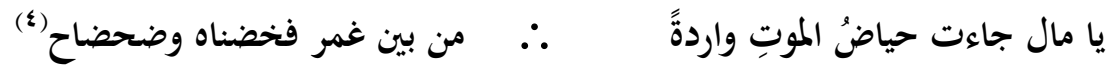

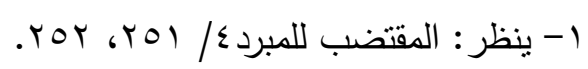

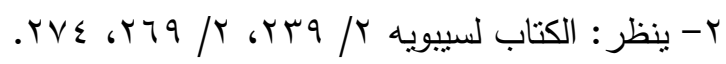

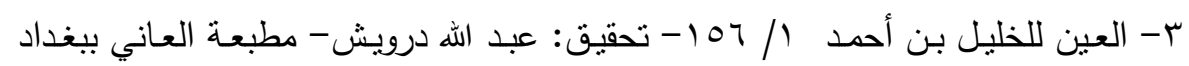
4Nאו أه. ـ - من البسيط لأبي حاتم الطائي في ديوانه ص ـ اهـ 10. 


\section{ملامح التزكيب والبنية في لغة بنى أسد في ضوء الشواهد الشعرية}

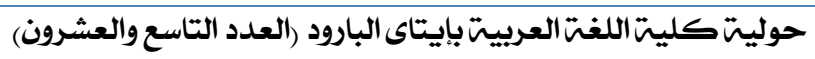

وفال لبيد بن ربيعة:

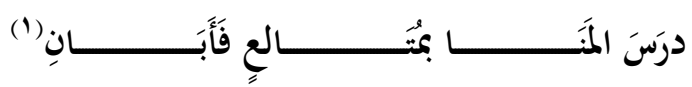

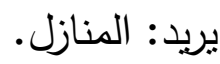

ونسبت الظاهرة لأسد أيضًا، فقد ذكر ابن منظور خلاف العلماء حول

كلمة "يافل" أي: يا فلان الترخيم وعدمه ونسب النطق لأسد (؟).

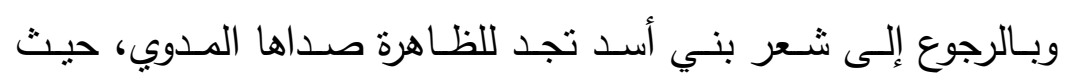

الثواهد الكثيرة للظاهرة من ذلك قول عبيد بن الأبرص:

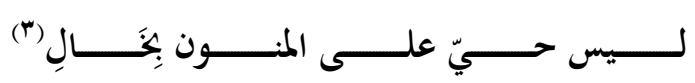

أي: بخالا

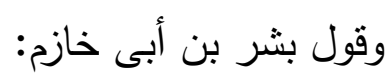

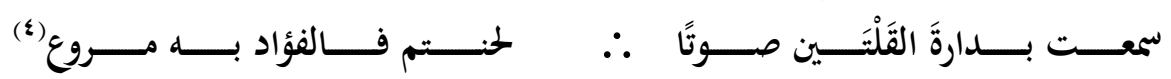

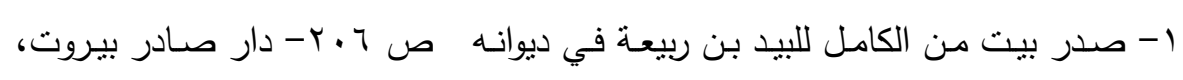

وعجزه:

وتقادمت بالحبس فالسُوبَان

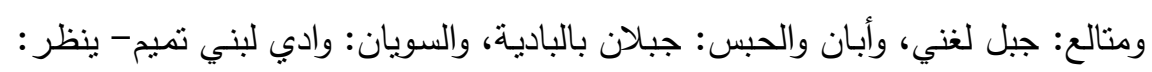

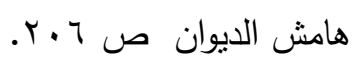

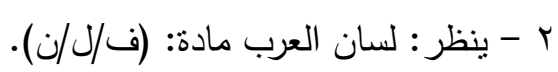

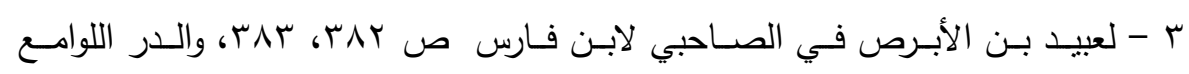
للشنقيطي / / ا l وليس في ديوانه، وصدره:

نكرت منا بعد معرفة لميس ومدرن

$$
\text { وعجزه في الكثاف r/ ror ro ror. }
$$

وبعد القصافي والشباب المكرم

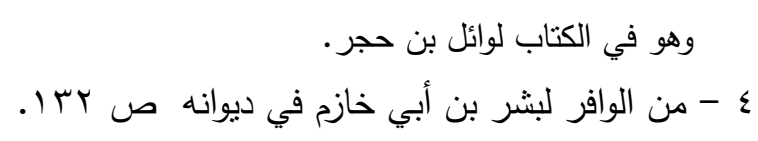




$$
\text { ملامح التزكيب والبنية في لغة بنى أسد في ضوء الشواهد الشعرية }
$$

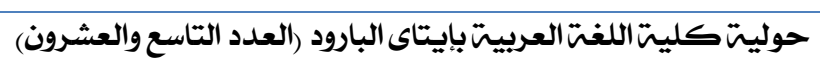

وقول الكميت:

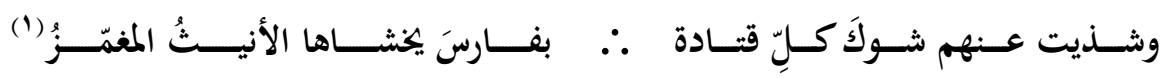

فلـيس المقطع أو ليسـت القطعـة خاصـة بطيـى وحـدها بـل ظـاهرة

معروفة لدى القبائل البدوية كأسد ولخم وتميم وسعد (؟).

وفي قبائل بدوية تعيش على مقربة من طيى وهذا القطع يتماشى مـع

قانون السهولة، والذي يقع كثيرًا في لغة البدو ويرجع بعض المحدثين حذف لفَ أواخر الكلمات، إلى الأخطاء السمعية التي تتجم عن ضعف بعض التض الأصوات،

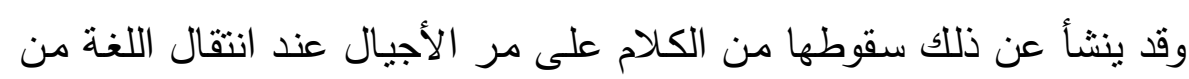

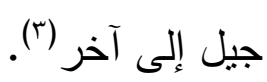

\section{$\hat{1} \hat{-10} \hat{0}$}

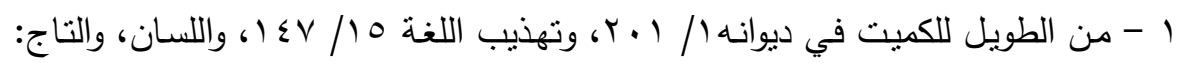
(أنت) ويقاس أصله يفارس فرحمه في غير النداء، وهو قطعة.

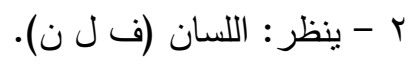

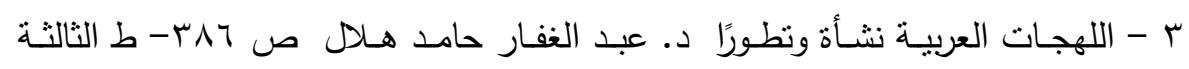
. 
ملامح التركيب والبنية في لغة بنى أسد في ضوء الشواهد الشعرية

حوليت كليت اللغت العربيت بإيتاى البارود (العدد التاسع والعشرون)

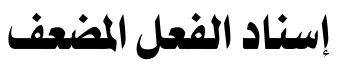

\section{إلى ضمائر الرفع المتحركة}

تتعد لغات العرب في هذا بين الفلك والإدغام والحذف والإبدال وغيرها:

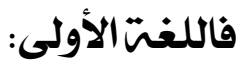

إنه إذا اتصل الفعل المضعف أو المضاعف بضمائر الرفع المتحركة، فالمستعمل والمشهور وهو ما عليه كلام العرب فلك التضعيف، وعدم الإدغام،

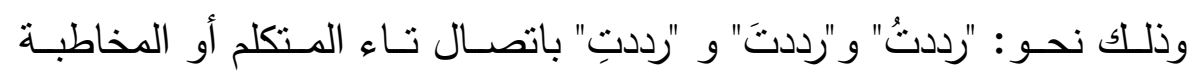
بالفعل و "رددنَ" و "رددنا" باتصال نون النسوة وناء الفاعلين.

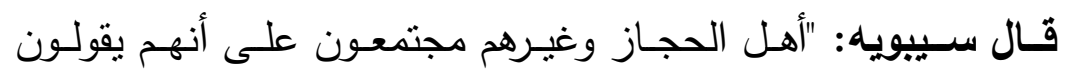
للنساء: "رددن" لأن الدال لم تكن هاهنا لأمر، ولا نهي، وكذلك كل حرف قبل

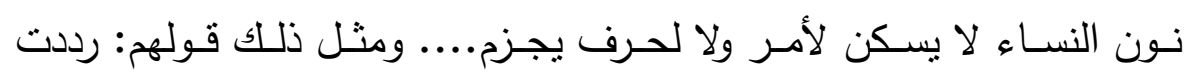
ومددت، لأن الحرف بني على هذه التاء، كما بني على النون وصار السكون بمنزلة فيما فيه نون النساء"(')

قال ابن عصفور: فسكون لام الفعل ثاني المضعف؛ لا يشبه سكون

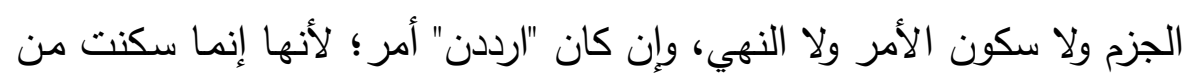
أجل النون كما سكنت من أجل التاء في "رددت"(؟). وذكر الشسيخ رضسي الدين: أن بني تميم وافقوا الحجازيين في فلك

الإدغام للزوم سكون الحرف الثاني من المضعف (ॅ).

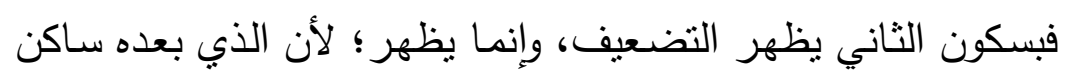

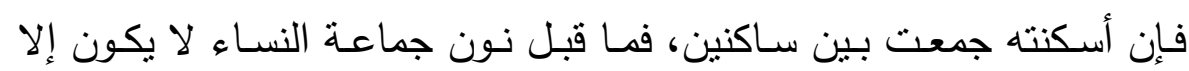

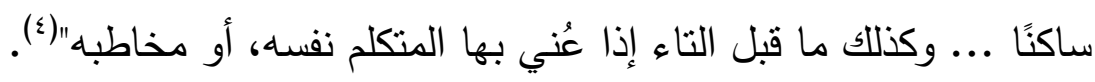

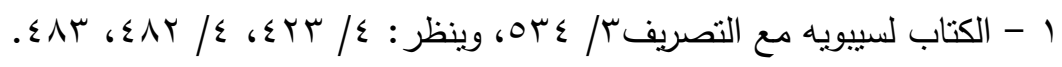

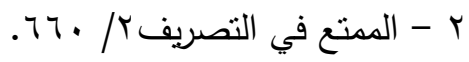

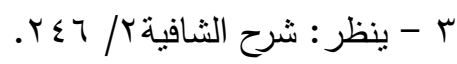

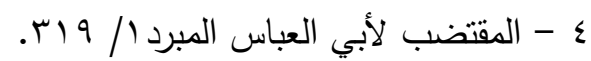




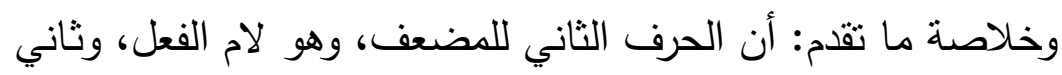

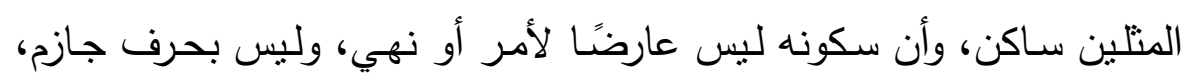

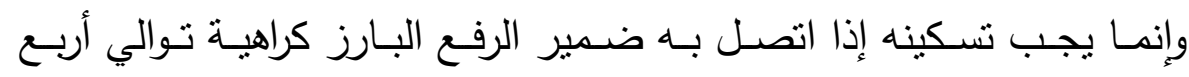

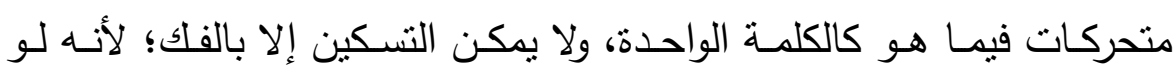

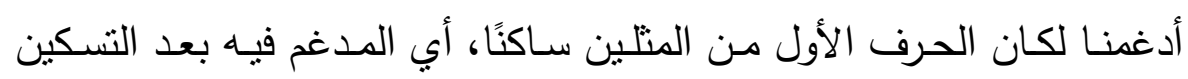
فيلزم بذلك التقاء ساكنين فيحرك الأول ويفك الإدغام (').

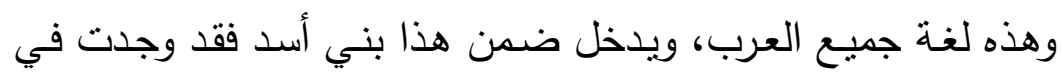
شعر بني أسد الفك مع وجود الضمير المتحرك، وذللك منل قول بشر : فئه

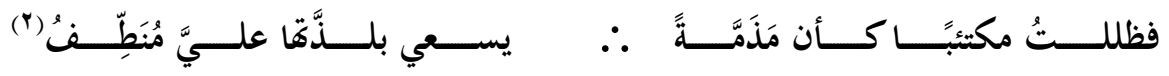
وقوله أيضًا:

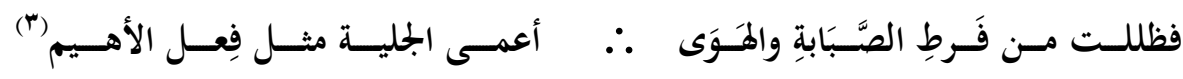
ومنه قول عبيد بن الأبرص:

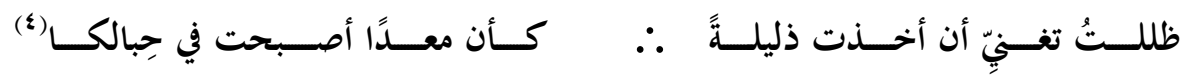
اللغنت الثانيتّ: يوجد من خالف الجمع السابق وهم قبيلة بكر بن وائل، فإنهم يدغمون

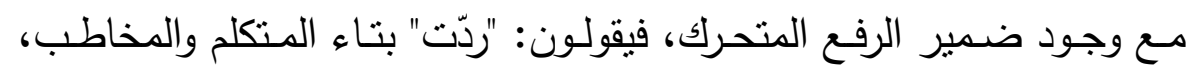
وردّنا، وردّن" بنا الفاعل ونون النسوة.

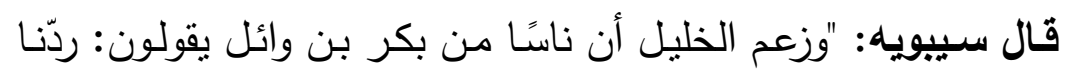
ومدّنا وردّن ومدّن، وردت ومدت ... وهذه لغة ضعيفة" (ه).

ا - ينظر : اللهجات العربية نثأة وتطورًا- د. عبد الغفار هلال ص ص ساب - ط: الثانية .

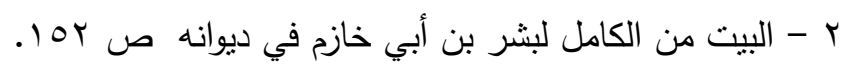

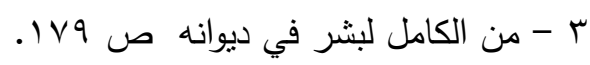

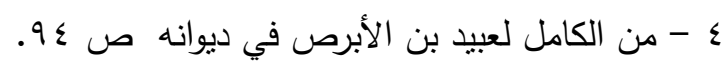

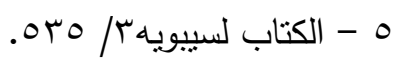




\section{الاستعمال وتلك اللغة:}

خرِّج على هذه اللغـة قراءة قرآنيـة كمـا خرج عليها عدد من رويـات

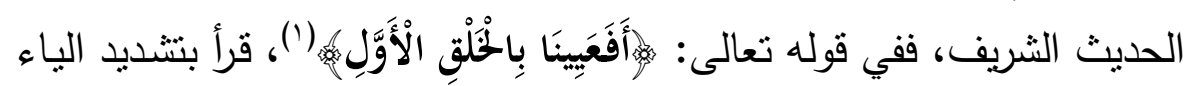
من غير إثباع في الثانية جماعة من القرّاء منهم أبي عبلة والوليد بن مسلم

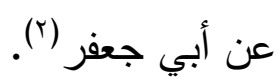

قال أبو حيان: "قرأ الجمهور بياء مكسورة بعدها ياء ساكنة، ماضي عنيّ كرضي، وقرأ ابن أبي علبة والوليد بن مسلم، والقوصي عن أبي جعفر،

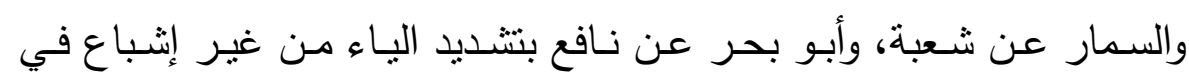

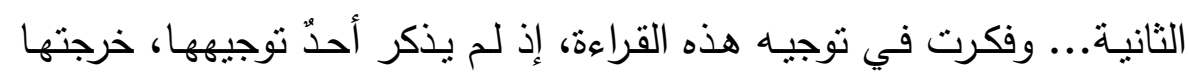
على لغة من أدغم الياء في الياء في الماضي....فلما أدغم ألحقته بضمير توفيه

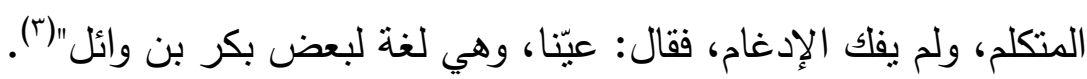

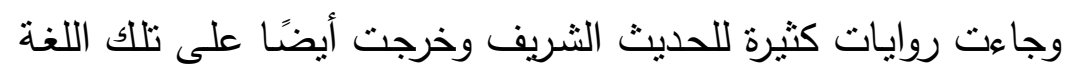

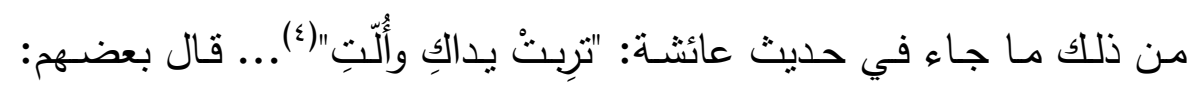
صـوابه: أللت بكسـر الـلام الأولى وسـكون الثانيـة على وزن طعنت، قـال: ومعناه: طعنت بالآلة، وهي الحربة على معنى أوعية العرب المعتادة في دعم

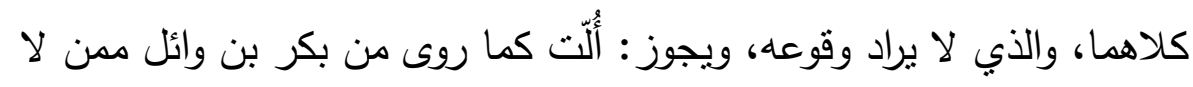

$$
\text { 1 - سورة ق : الآية (10). }
$$

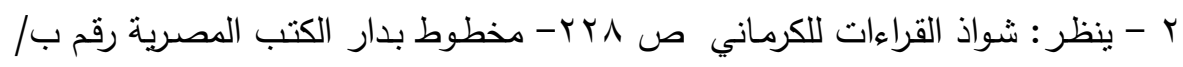

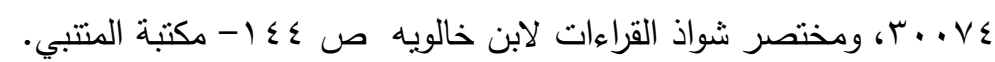

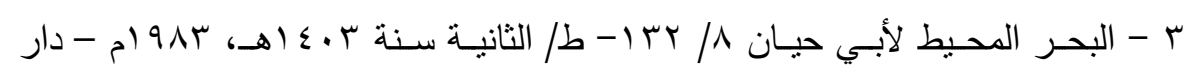
الفكر . (الف ـ - الحديث في صحيح مسلم كتاب الحيض- باب وجوب الغسل على المرأة بخروج

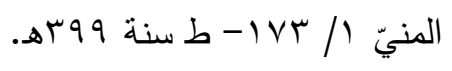




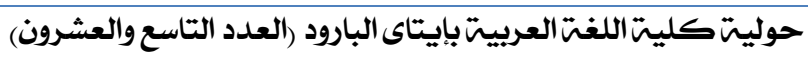

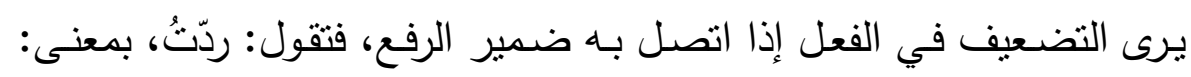

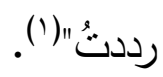

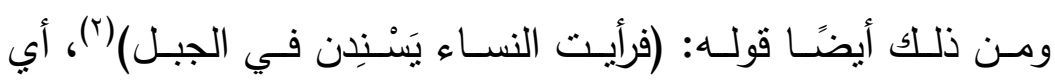

يصعدون بالنون والسين المهملة .. قال ابن الأثير:"... والذي جاء في كتاب لئ البخاري يشدّن بدال واحدة، والذي جاء غيرهما بسندون بسين مهملة ونون أي: يصعدون فيه، فإن صحت الكلمة على ما في كتب الحديث، وهو قبيح في

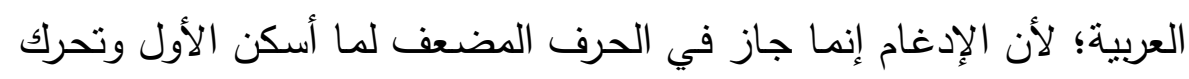
التاني، وأما مع جماعة النساء، فإن التضعيف يظهر؛ لأن ما قبل نون النساء إنهاء

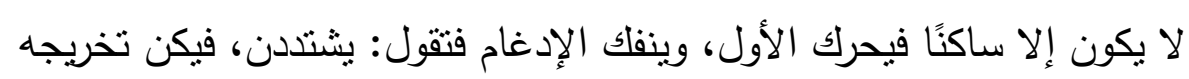

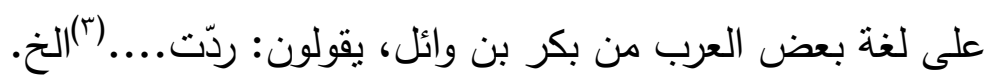

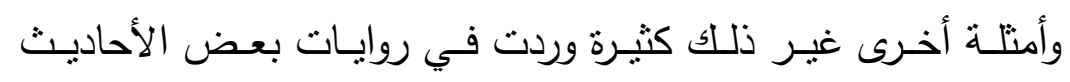

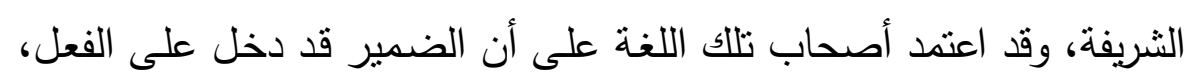
وهو مدغم فلم يفكوا الإدغام لعروض الضمير على الفعل. قال ابـن عصفور: "كأنهم قد روا الإدغام قبل دخول النون والتاء:

فأبقوا اللفظ على ما كان عليه قبل دخولها (ء). وإذا كان الفك هو القياس في هذه الحالة، فإن الإدغام مخالف لما فـا

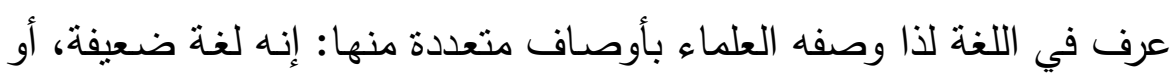
إنها لُغيّة، أو تركيب قبيح، أو لغة رديئة فاشية في عوام أهل بغداد(ه).

1 - ينظر : مشارق الأنوار على صحاح الآثار للقاضي عياض / / آم.

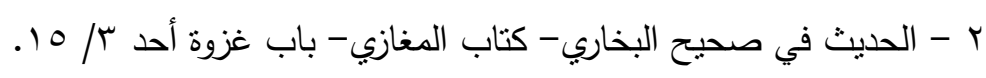

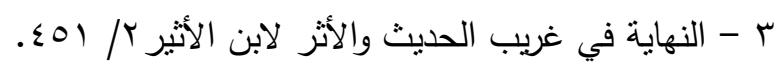

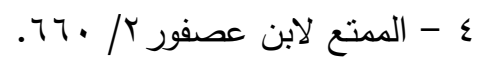
0

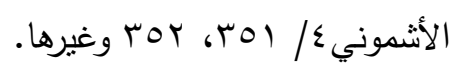


الإدغام مع زيادة ألف بين الفعل والضمير : حدوث الإدغام تسبب في

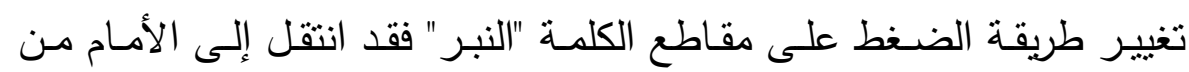
المقطع "رد" مثناًا إلى المقطع "د"، وانتقال النبر إلى مثل هذا المقطع قد يطيل صوت اللين فيصبح "دا"، ولهذا ذكر بعض المحدثين (')"

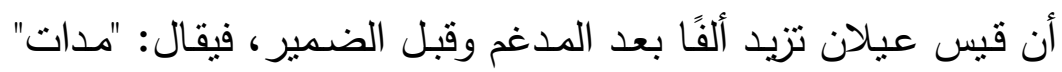
لكنه لم يشر إلى مصدر تلك النسبة. ويرى الباحث ترجيح نسبتها لبعض بني بكر وائل بدليل العطف وعود

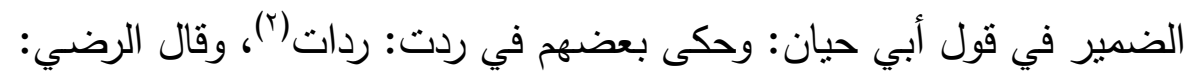
وجاء في لغة شاذ قليل وبعضها يزيد ألفًا بعد الإدغام نحو ردات ليقى ما قبل

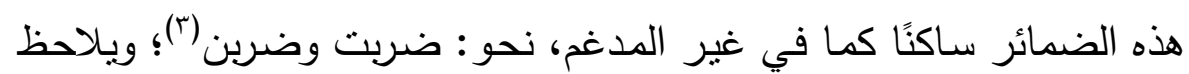
أن هذه اللغـة جمعت بين المحافظـة على الإدغـام وبقاء مـا قبـل الضـمائر ساكنًا. اللغتت الرابعتَ، الخامستة: تلجأ طائفة أخرى إلى التخفيف من اجتمـاع المتمـاتلين عند اتصـال

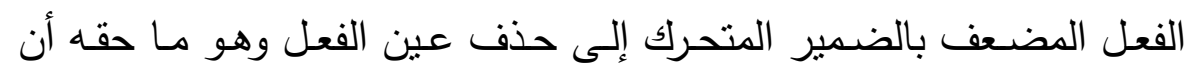
يدغم فيما بعده وبتخذ ذلك طريقين: الأول: وهو اللغة الرابعة: الحذف مع نقل الحركة، فيقولون في نحو : ظللت، ومِسست وأحستت: ظِلِّت، مِست، حِست. الثثاني: وهو اللغة الخامسة: الحذف مع الفتح، فيقولون: ظلَت ومَست وأَحست. 1 - كتاب: مميزات لغات العرب - أ. حفني ناصف بك ص ص عب - ط. ثانيـة مطبعة

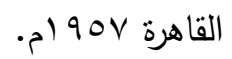
r - ينظر : ارتثاف الضرب لأبي حيان / / 170 - - تحقيق: د. مصطفى النماس .

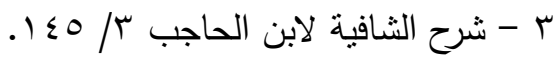




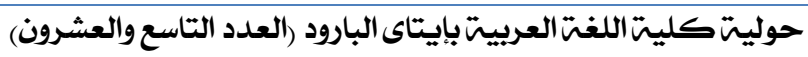

وقد ذكر سيبويه اللغتين السابقتين، فقال: "ومثل قولهم: ظِلت ومِست حذفوا وألحقوا الحركة على الفاء، كما قالوا: خِفَت وليس هذا النوع إلا شـاذَّا، والأصل في هذا عربي كثير ، وذلك قولك أحستت، ومسسّت، وظللت، وأما

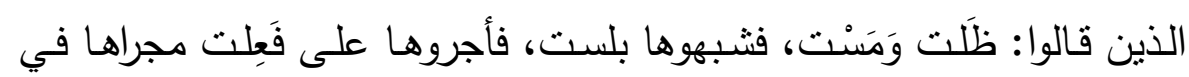
"فَفَل" وكرهوا تحريك اللام فحذفوا، ولم يقولوا في فَعِلتُ لست البتة، لأنسه لم

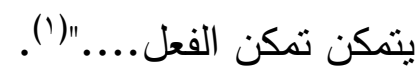

وقال الفراء(r):" وقد تقول العرب ما أحست بهم أحدًا فيحذفون السين

الأولى، وكذلك رددت، ومسست، قال: وأنشد بعضهم:

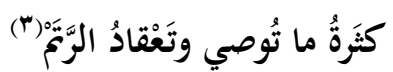

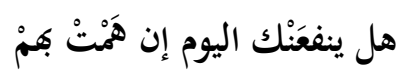

وكذا ذكر اللغتين غيرهما من العلماء(๕).

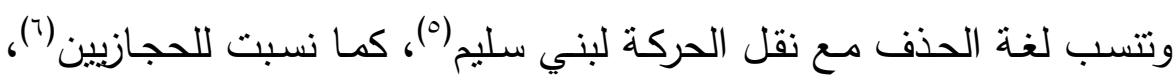
ولغة الحذف مع عدم النقل أو مع الفتح لبني عامر وبني تميم(Y)، كما بمكن

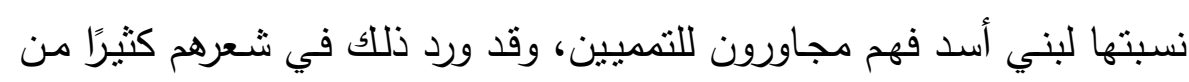
ذلك قول بشر بن أبي خازم:

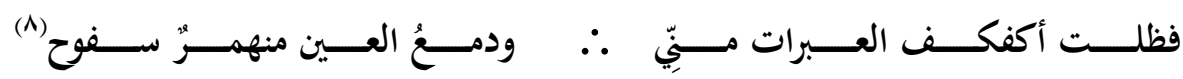

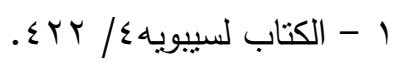

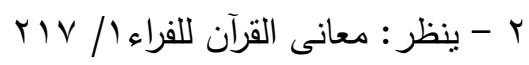

r - الرجز بلا نسبة في أساس البلاغة (رتم) ولسان العرب (رنم)، والتاج (رنم).

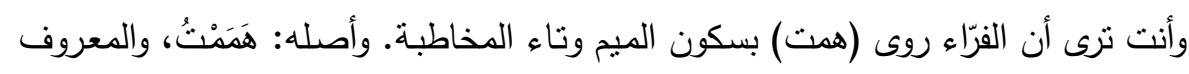
في الرواية (همت بتتديد الميم مفتوحة وتاء التأنيث الساكنة.

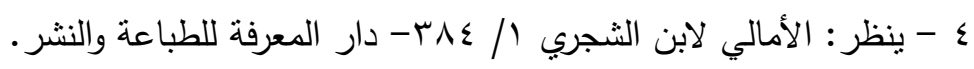

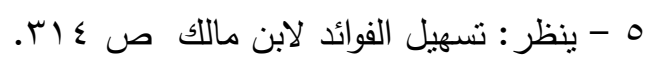

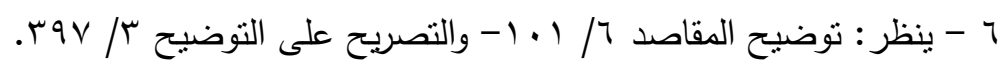

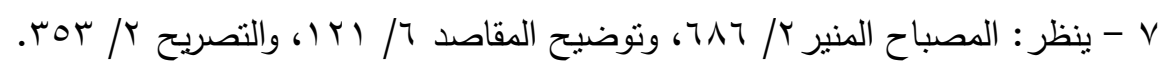

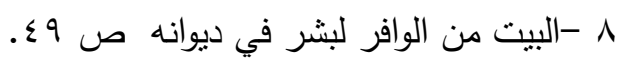




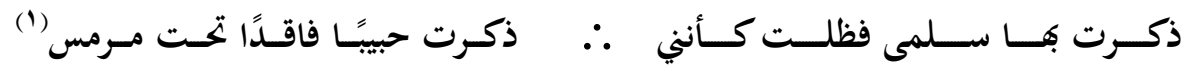
وقول عبيد بن الأبرص: - مقاص:

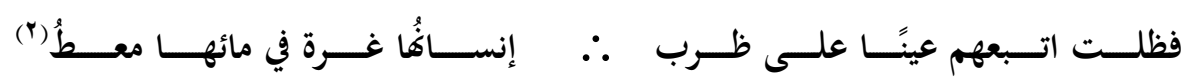
وقوله أيضًا:

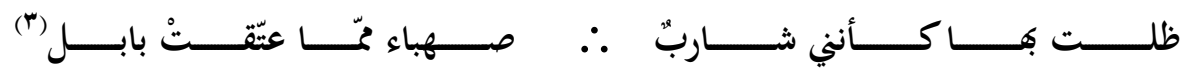

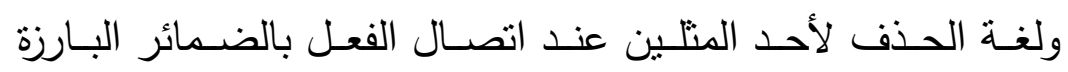
المتحركة أثهر وأعرف من لغة الإدغام، فالتلفظ بها لا يؤدي إلى لبس كما أنه

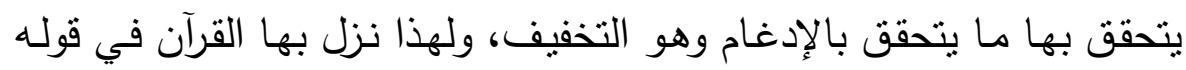

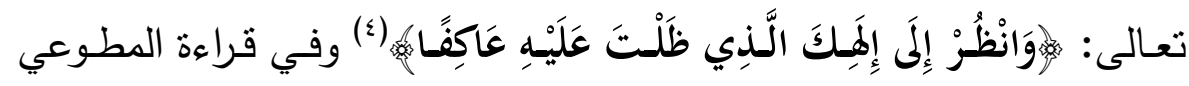
"ظِلِت" بكسر الطاء، كما وردت في الثـعر وهذا واضـح من الأشعار السـابقة على هذه اللغة، كما وردت في روية بعض الأحاديث السابقة أيضًا، وإذا كان الإدغام والحذف وسيلنين للتخفيف من فلك التضعيف، فإن هناك وسيلة ثالثة وردت عن العرب مثل قولهم في تظننت وتنسررت، تظنيت وتسريت، وهذه اللغة السادسة في المضعف: وهي إبدال ثاني المثلين إلى ياء، وقد وردت في كلمة أملى عن تميم وقيس في قبائل الفلك عند الحجازيين وبني أسد وجاءت

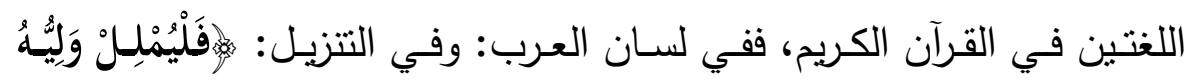

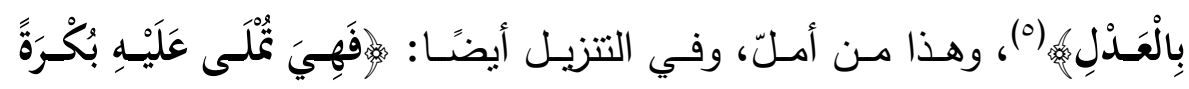

1 - البيت من الطويل لبشر في ديوانه ص . . 1، وانظر : مختارات ابن الثجري ص

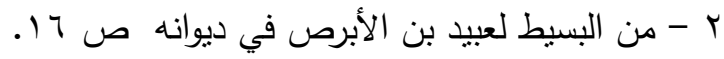

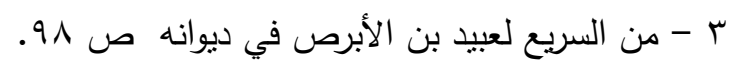
ع- سورة طه الآية وV.

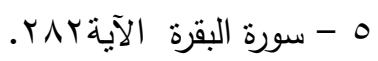




$$
\text { ملامح التركيب والبنية في لغة بنى أسد في ضوء الشواهد الشعرية }
$$

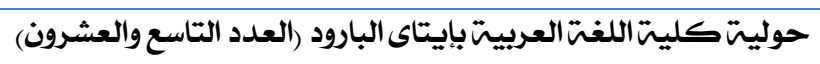

وَأَصِيلًا (') وهذا من أملى، وحكى أبو يزيد: أنا أملل عليه الكتاب بإظهار التضعيف، وقال الفراء: أملات لغة أهل الحجاز ، وبني أسد، وأمليت لغة وهن بني تميم وقيس، ويقال: أملّ عليه شينًا يكتبه، وأملى عليه، ونزل القرآن العزيز باللغتين معًا، ويقال: أمللت عليه الكتاب، وأمليته(؟). فإذا كان في الإدغام وهو المماثلة الكاملة نوععمن أنواع التخفيف، فإنهان في المخالفة بالإبدال لأحد المثلين ياء، وكذا حذف أحدهما نوع من السهولة أيضًا.

ويلاحظ أن بني أسد اتبعت منهج التميميين في الحذف مع عدم النقل في نحو ظلت، واتبعت الحجازيين في لفظ "أملل" بعدم الإبدال وهذا إنما يعني أن اللغات لا تسير على وتيرة واحدة في نطقها. $0 \hat{0}$ 


\section{الاستثثباي}

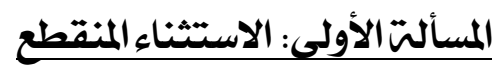

لبني أسد في الاستثناء المنقطع منهجًا يتفق مـع منهج تمبيم غير أنـه لم

ينسب إلبهم واكتفى العلمـاء بنسبة ذلك لتميم وحده فالحجازبين بنصبون المستنتى المنقطع، وهو ما كان المستثىى من غير جنس المستثنى منه، فيقولون: ما انصرف

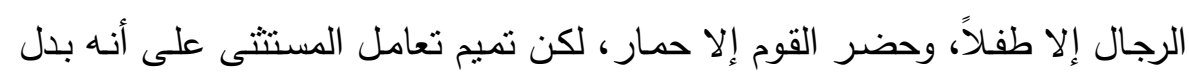

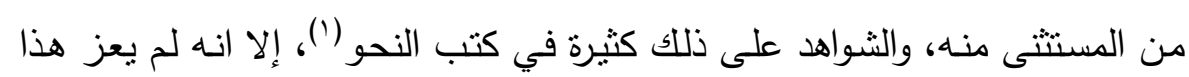

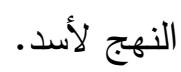

ويرى د/ رمضان عبد التواب أن هذا العزو لتميم وحدها قائم على الاستقراء

الناقص، وساق شاهدًا من شعر بني أسد على الاتباع وذلك، قول ضرار بن الأزور:

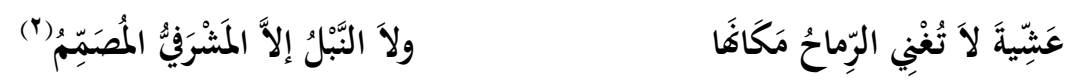

وساق أحد الباحثين شاهدًا آخر لبشر ابن أبي خازم وهو قوله:

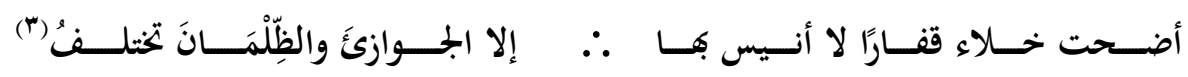
وهذا يدل على أصالة الظاهرة عند النجديين جميعًا، وخاصة بني أسد.

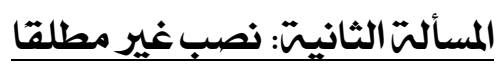

ذكر الفراء()؛: إن بعض بني أسد بنصبون غير مطلقًا ثم الكلام قبلها أو لم

ينظم وأنشد:

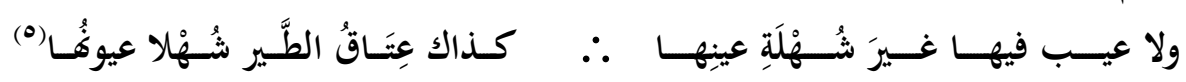
كما أنثد لأبي قيس بن الأسلت:

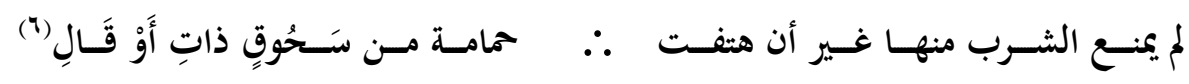

1 - انظر في هذه المسألة كتب النحو المختلفة باب الاستثناء والاستثناء المنقطع.

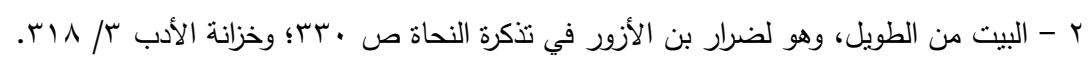

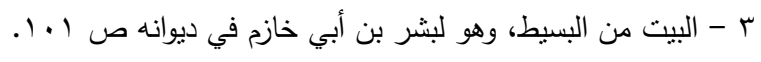

ع - ينظر : لسان العرب مادة "غير".

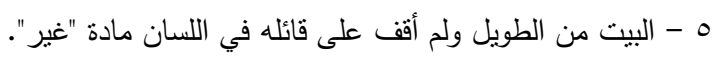

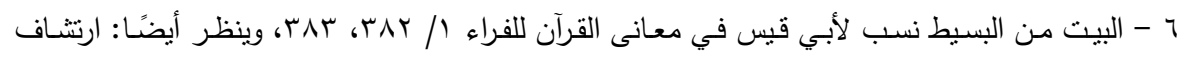

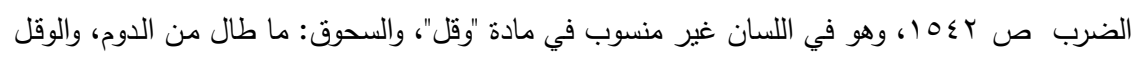
تمارة، وجمعه أو قال والرواية بالفتح لغير في اللسان. 


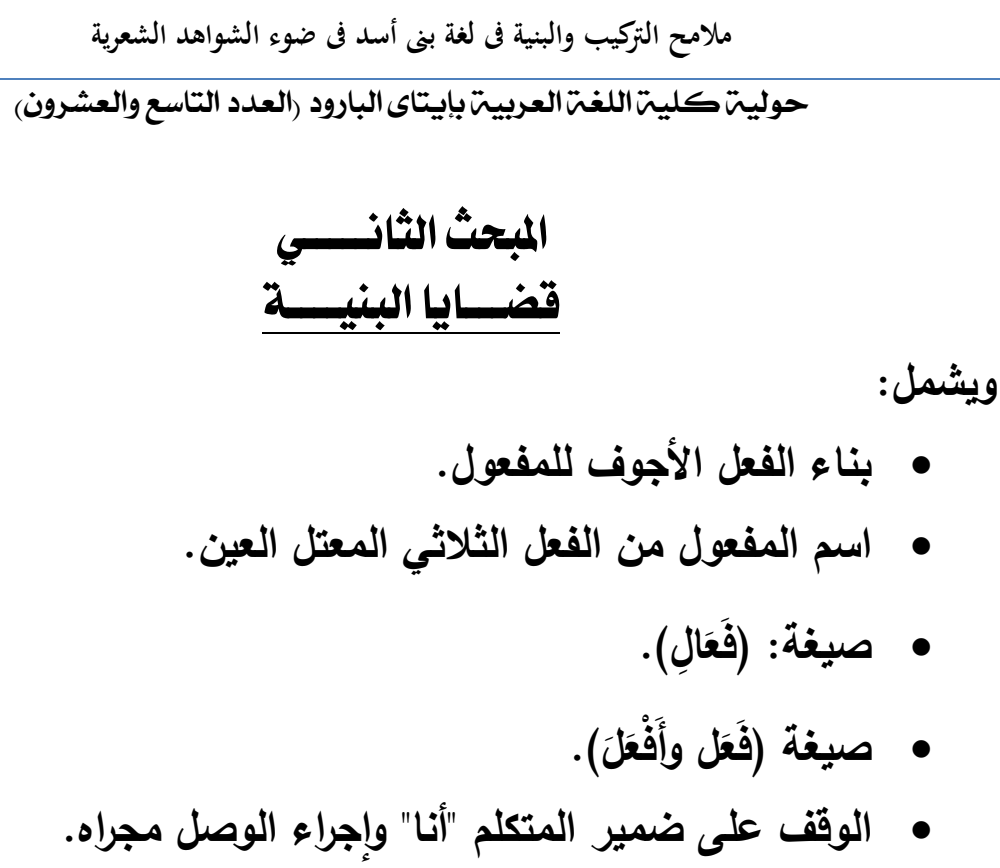




$$
\text { ملامح التركيب والبنية في لغة بنى أسد في ضوء الشواهد الشعرية }
$$

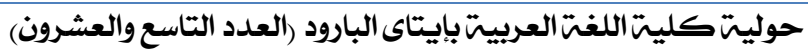

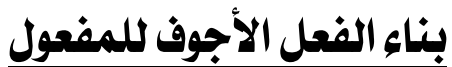

الفعل الأجوف المبني للمجهول ذكر العلماء في لغات متعددة، وهي: ا- إخلاص الكسر في نحو قيل، بيع سواء أكان يائًًا أو واويًا، ففي الواو وهئ

تغلب الكسرة، فتقلب الواو ياء، وذلك نحو: قيل، "وسيق".

r- أن تشم الكسرة الضم، وهذا يدرك بالسماع.(')

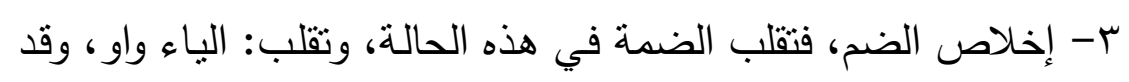

نسـب لأسد الإثـمام، كمـا نسـب إلبهم إخـلاص الضـم فقي اللسـان:

$$
\text { الفراء: بنو أسد يقولون: قُول، وقيل بمعنى واحد وأنشد: }
$$

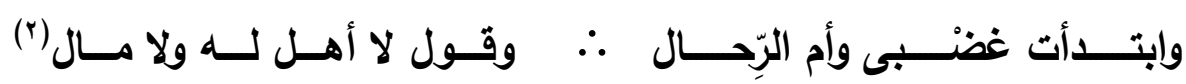

قول بمعنى: قيل (r)

وخص أبو حيان إخلاص الضم لفقعس ودبير (؛).

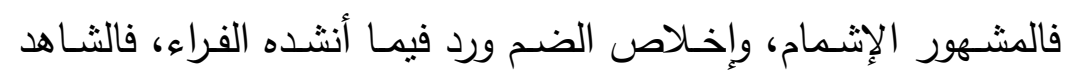
الثعري يؤيده.

\section{$\{\hat{1}$}

I - ينظر في هذا كتب النحو وعلى سبيل المثال ارتنشاف الضرب لأبي حيان ص عـا1،

$$
.1 r \leqslant r
$$

r - من البسيط ولم أقف على قائله في لسان العرب مادة: "قول".

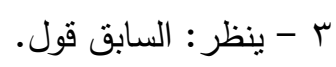

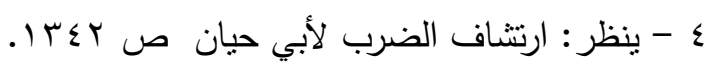




\section{حوليتّكليت اللغت العربيتة بإيتاى البارود (العدد التاسع والعشرون) اسم المفعول من الفعل الثلاثي المعتل العين}

اسم الدفعول من كل فعل ثلاثي معتل العين يصاغ عند أهل الحجاز

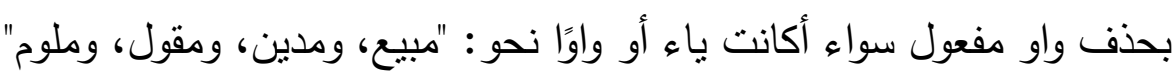

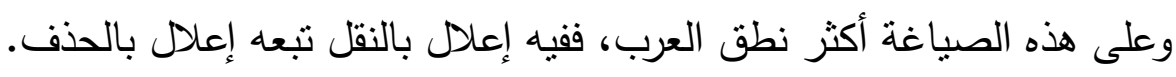

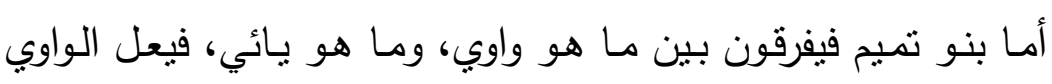

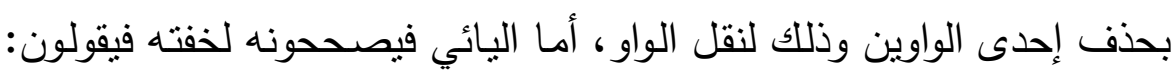

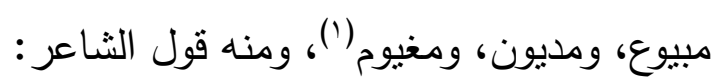

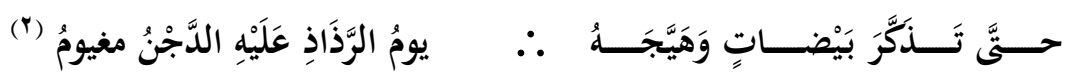

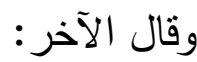

\section{(")....}

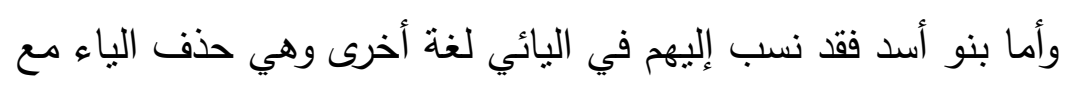

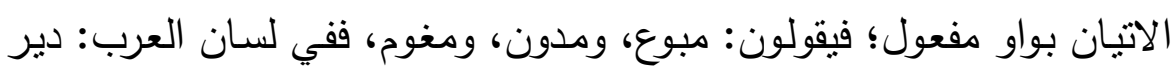

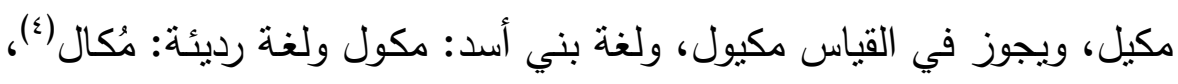
والآخيرة بالألف مع ضم في الميم وفتح الكاف. لكئ. ففي الكلمة: أربع لغات: مَكِيل، ومكيول، ومكول، ومُكال. وقد رتب الأزهري اللغات حسب درجتها في الفصاحة إلى الآتي:

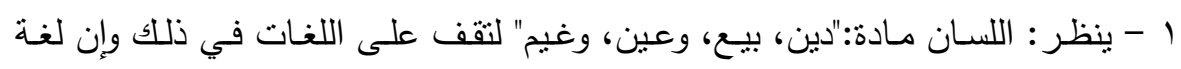

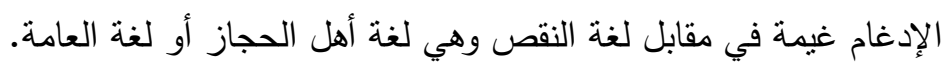

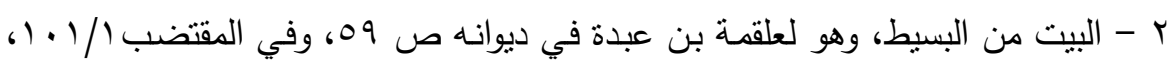

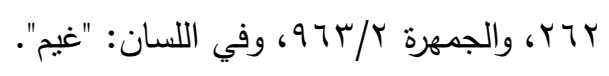

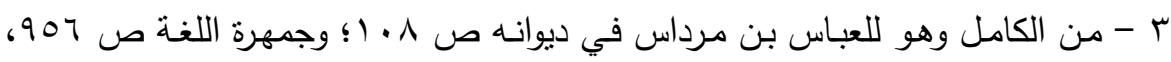

$$
\text { واللسان (عين) وصدره: }
$$

قد كان قومك يحسبونك سيدا 


\section{حوليتشكليت اللغتا العربيتبايتاى البارود (العدد التاسع والعشرون)}

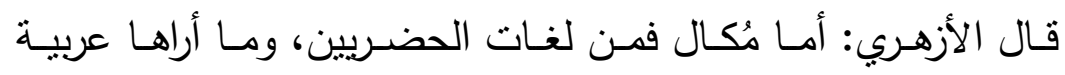

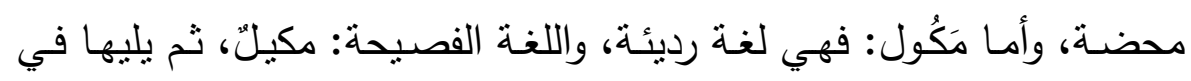

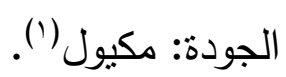

فالحجازيون وعامة العرب حذفوا واو مفعول وأبقوا الياء مع نقل حركة

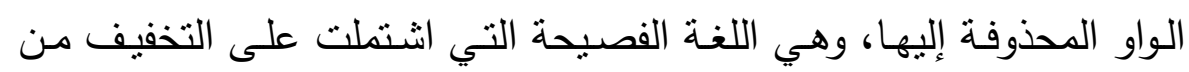

النقل، وتنسى لغة النقص (؟).

وأمسا التميميون فيجمعون بين الباء، واو مفعول فلا يعلون ذلك لخفة

الياء وهذا هو القياس الأصلي أو اللغة القديمة التي حافظت على الأصل، ولم

تحدث تطورًا لحروف العلة، وتسمى هذه لغة الإدغام (r).

وأما بنو أسد فأعلوا الياء بحذفها وأبقوا على واو مفعول، وقده الإدعام اعتبرها

الأزهري لغة ردئية؛ حيث حذف منها حرف أصلي وأبقوا واو مفعول، ولم يعد

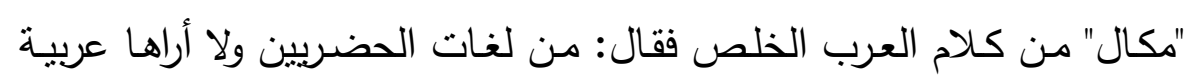

محضـة، فهذه الصيخة تؤدي إلى فساد البناء حيث أبدلوا الكسرة فتحة وأبدلوا

الياء ألفًا.

واللغـة الأولى والثالثة تشتـل على مقطـع مـن النـوع الأول القصـير

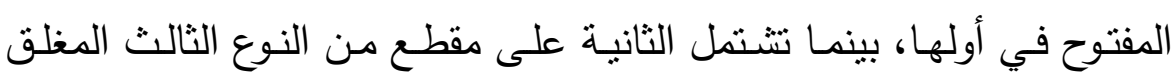
المتوسط في أولها أيضًا، والميل إلى المقاطع المغلقة من سمات العربية.

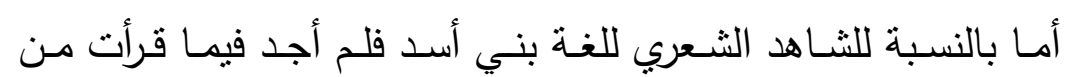

أثعارهم بينًا يؤكد الظاهرة لديهم إلا أنها ثابنة لهم برواية المعاجم لها.

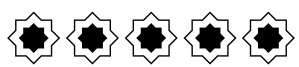

1 - ينظر : التهذيب: "كيل" واللسان: "كيل".

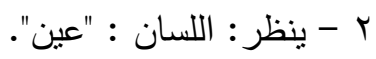

r - بنظر : اللسان : "عين". 


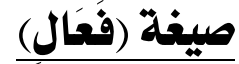

تأتي هذه لمعاني متعددة منها ما يتفق العرب على نطقه ومنها ما يختلف فيه من البناء على الكسر أو الفتح، وتفصل ذلك كما يلي: أولاً: ما يتفق العرب في بنائه الكسر من هذا المعاني ما يأتي: أ- أن يكون وصفًا لمؤنث جاري مجرى الأعلام سواء أكان منادى، مثل: (يا

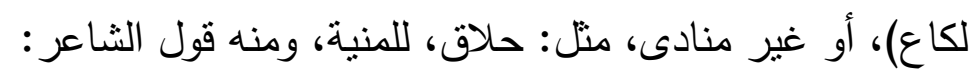

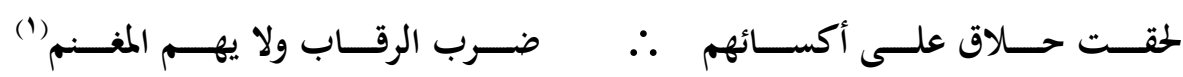
ب- أن تكون مصدرًا معدولاً مثل: فجار ، ومنه قول الثاعر:

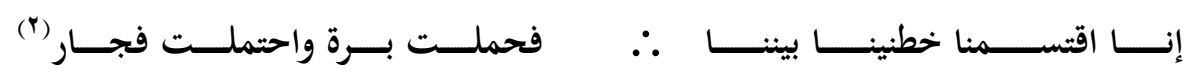
ج- أن تكون حالا مبنية على هذا الوزن منل قول الثاعر : وشربت من لبن المحلق شربة ثانيًا: ما يختلف العرب في بنائه من هذا ما يأتي:

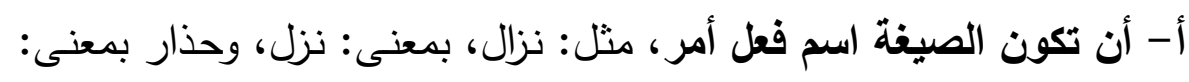
احذر، وهو بهذا المعنى يبنيه جميع العرب على الكسر إلا بني أسد فإنهم يبنونه على الفتح (ء).

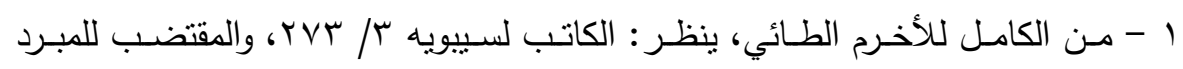

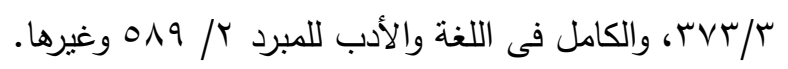

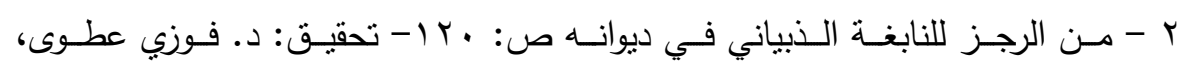

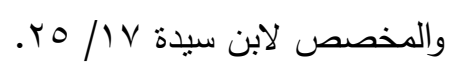

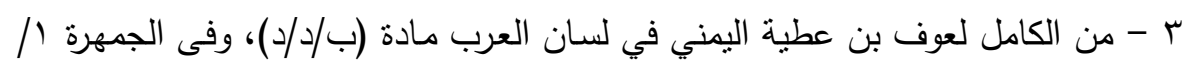

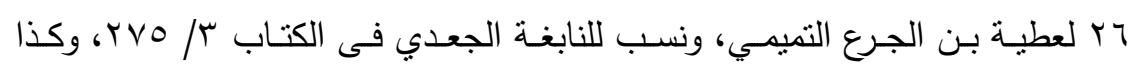

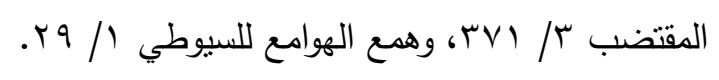

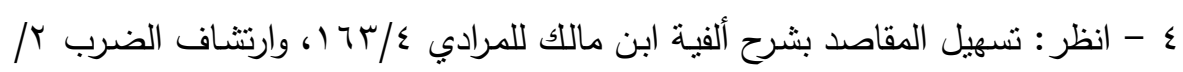
ا (1)، واللسان مادة (منع). 


\section{حوليتشكليتاللغتا العربيتبايتاى البارود (العدد التاسع والعشرون)}

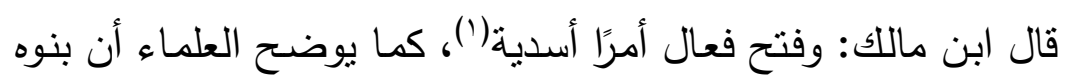

كذلك طلبًا للخفة(؟). لكنه بالرجوع إلى شعر بني أسد تجد أنهم يسيرون على الى

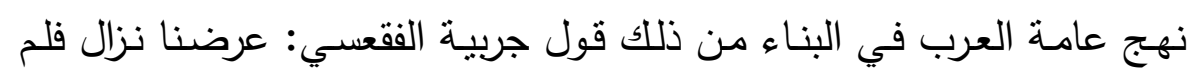
ينزلوا... وكانت نزال عليهم أطم(r)، فنزال على وزن فعال: اسم فعل أمر مبني على الكسر ، بمعنى: انزل.

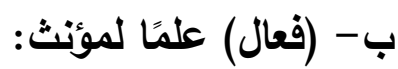

(فعال) بهذا المعنى يختلف العرب فيـه، فأهل الحجـاز يبنونـه على

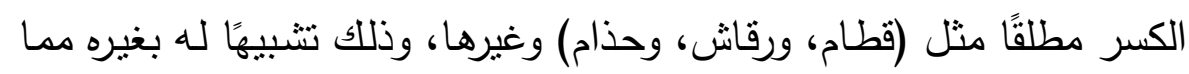

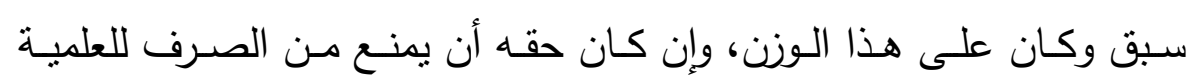

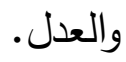

وأما بنو تميم فيعربونه إعراب مالا ينصرف، وذلك إذا لم يكن آخره راء بل أن جميع أهل نجد يجرونه هذا المجرى، فيقولون: هذا رقاشُ بالرفع، ورأيت رقاش، ومررت برقاش (ء).

وإذا كان آخره راء فإن جمهور التميميين بتبعون أهل الحجاز فى البناء

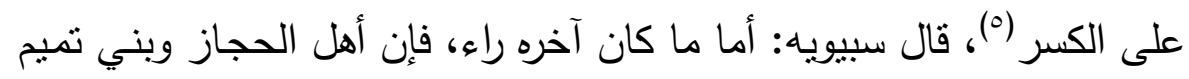
فيه متفقون ويختار بنو تميم فيه لغة أهل الحجاز "(؟).

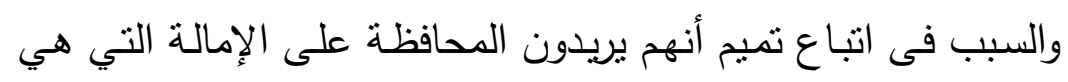

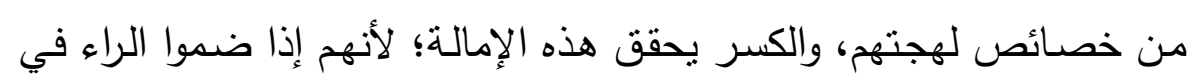

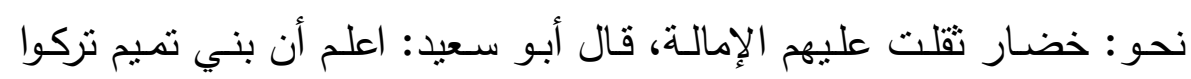

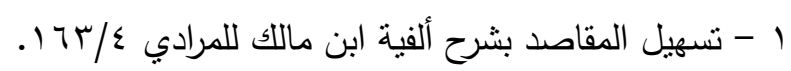

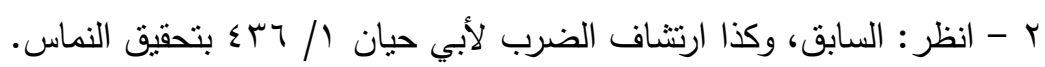

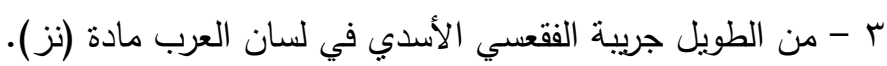

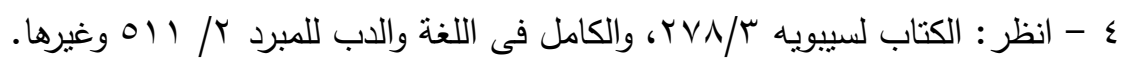
ه - انظر : السابق نفس الصفحات.

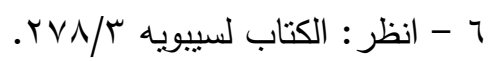




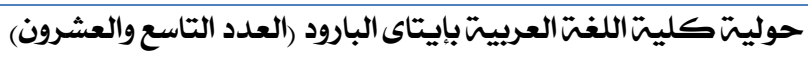

لغتهم في نحو قولهم: خضـار، وسفار وتبعوا لغـة أهل الحجاز بسبب الراء تقالت عليهم الإمالة، وإذا كسروا خفت الإمالة أكثر من خفتها من غير الراء؛ لأن الراء حرف مكرر والكسرة فيها مكررة، كأنها كسرنان فصار كسر الراء أقوى فى الإمالة من كسر غيرها وصسار ضم الراء في منع الإمالة أثند من

$$
\text { منع غيرها من الحروف (') }
$$

وما بنطبق على بني تميم بنطبق على بني أسد وأهل نجد جميعًا، إلا

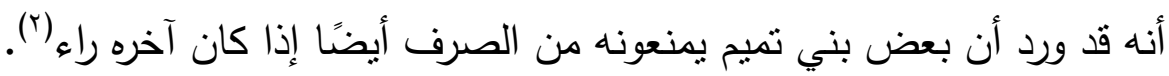

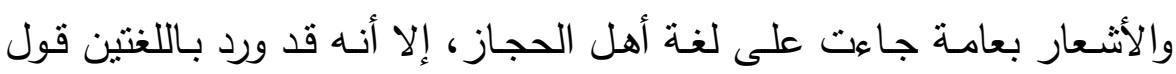

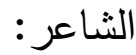

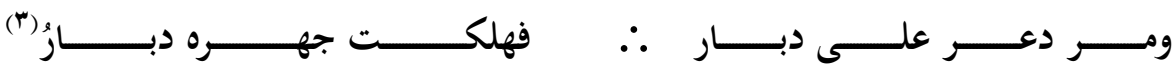
وقد عثرت على بيت لأبي المهوس الأسدي بالكسر في قوله:

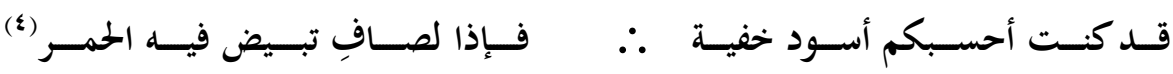
فلصاف مبنية على الكسر على وزن (فعال) اسم موضع من منازل بني تميم. وجـاءت اللفظـة نفسـها معربـة إعـراب الممنوع مـن الصـرف، قـال الجوهري: وبعضـهم يعربـه ويجريـه مجـرى مـالا ينصـرف مـن الأسـماء قـال ابـن بـري مهري وشاهده:

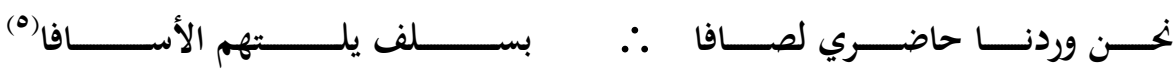
ونخلص مما سبق أن صيغة (فعال) تبنى على الكسر مطلقًا إذا لم تكن علما لمؤنث، ويتفق في ذلك الحجازيون والتميميون وسائر العرب إلا بني أسد، فإنهم يبنونه على الفتح إذا كان (فعال) اسم فعل أمر ، وإذا كان (فعال)

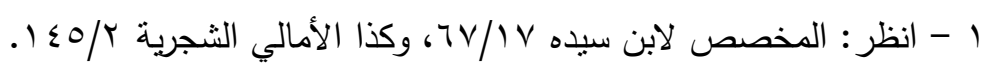

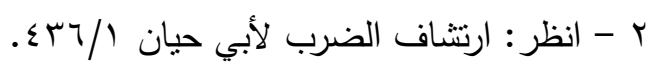

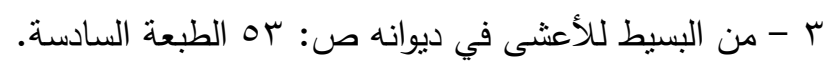
ع - من البسيط فى اللسان مادة (لصف). ه -من البسيط فى الصحاح: (لصف) واللسان: (لصف). 
ملامح التزكيب والبنية في لغة بنى أسد في ضوء الشواهد الشعرية

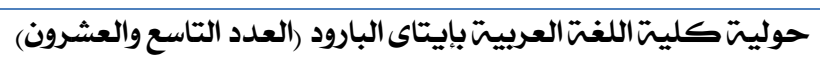

علما لمؤنث، فإن الحجازيين يبنونـه على الكسر أما بنو تميم، فإن جمهورهم

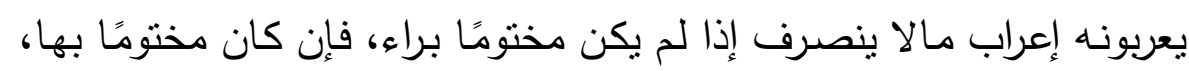
فإنهم يسلكون مسلك الحجازبين فى البناء على الكسر حتى يمكنه ذلك من

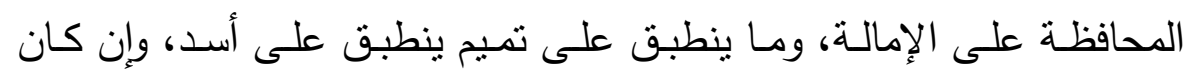
بعض التميمبين يعربونه إعراب مالا ينصرف.

$\{\hat{1} \mathbf{1}\}$ 


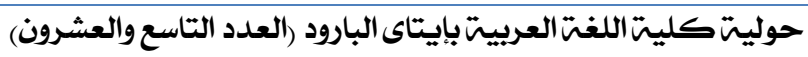

\section{صيخة (فَعَل وأفْهَلَ)}

من الصيغ التي تتنرك فى المعنى، ويكون اختلاف نطق القبائل سبيًا فى اختلاف اللفظ صيغتي (فعل وأفعل) وقد جاءت الصيغتان في لغـة أسد ونطقت (بفعل) في مقابل نطق غيرهم أفعل في بعض المواد، والعكس من وفن ونس ذللك: (جن، وأجن).

ذكر العلماء أنه يقال: جنه الليل وأجنه وجن عليه(')، كما ذكروا أن أن أن أنهن جن لغة أسد، وأجن لغة تميم، وهي أفصـح من الأولى (r)، وأنكر الأصمعي:

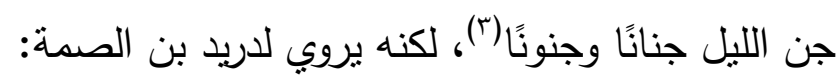

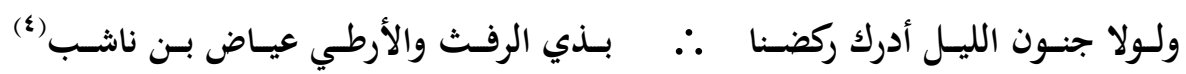
ويرى: ولولا جنان الليل (o) أيضًا. وجاءت فى القراءات القرآنية (عندها جنـةُ المأوى)(َ) فهذا يدل على ولى صحة اللغتين فى المعنى.

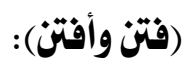

إذا كانت أسد قد نطقت بالصيغة الثناثية في جن فقد اختارت الصيغة

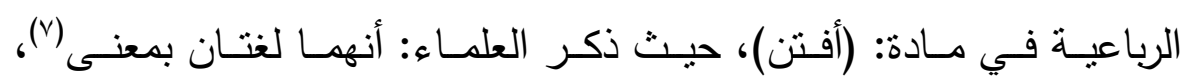

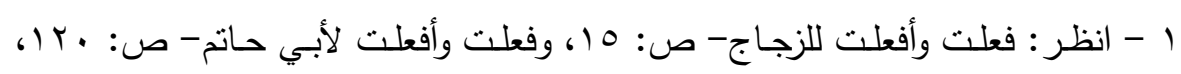

$$
\text { واللسان (جنن). }
$$

r - التبيان في تفسير القرآن \& / 190.

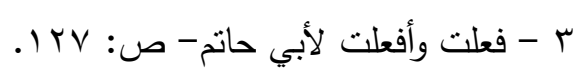

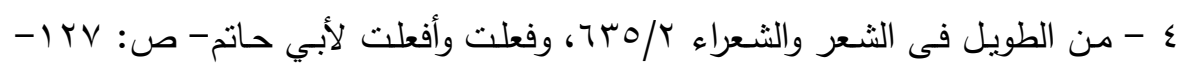

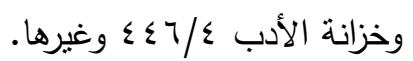

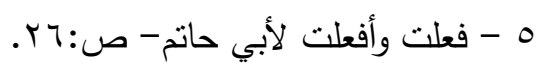

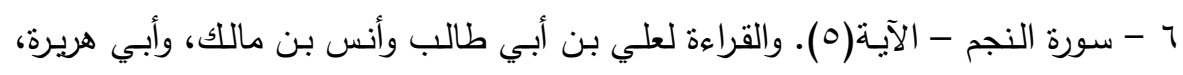

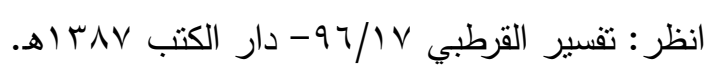

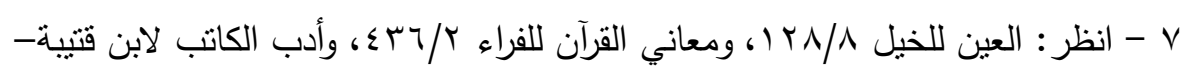

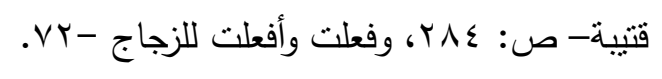




\section{حوليتّكليتا اللغتّالعربيتبايتاى البارود (العدد التاسع والعشرون)}

واستشـهوا على ذلك بالثـعر والنثر، فمن الجمع بين اللغتين في بيت واحد، قول الثاعر:

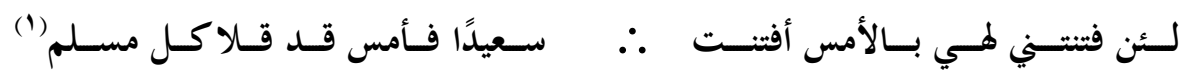

وقال رؤبة: يعرض إعراضًا لدين المفنت (؟).

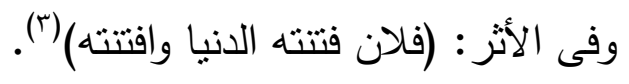

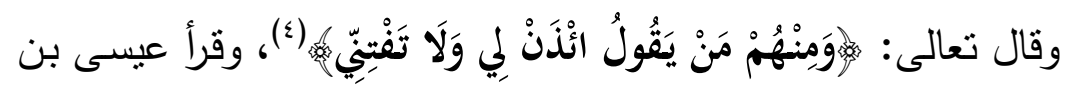

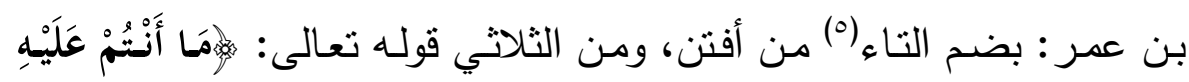

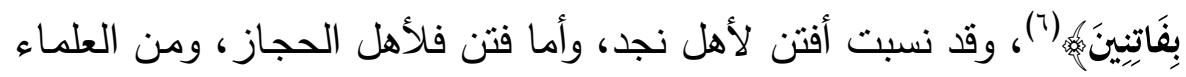

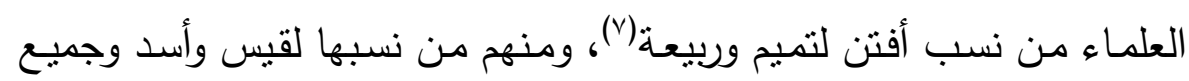

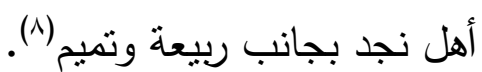
وإذا كانت قبيلة أسد قد نطقت مرة؛ بفعل، ومرة بأفعل، فهذا يعني أن اللغات ونمئ لا تسـير على وتيـرة واحـدة في نطقهـا وتطورهـا، وأنهـا لا تعـرف القـوانين الصارمة.

لكني أميلـل إلى أن: اختيـار الصيخة الرباعيـة هو الغالب في نطق القبائل البدوية كأسد حيث يميلون إلى طول البنية، وقد أثبت ذلك من خلاء

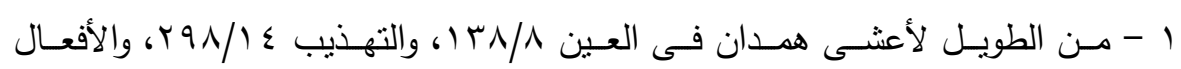
للسرقسطي \&/ آ واللسان (فتن).

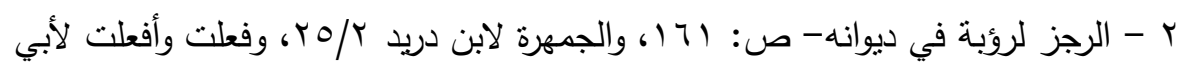

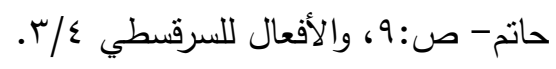

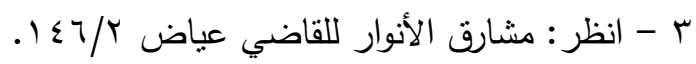

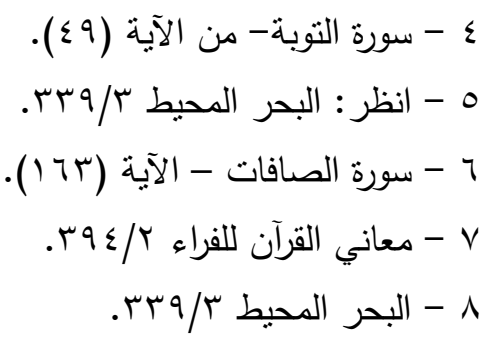




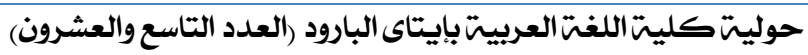

بحثي الاشتراك فى الصيخ الصرفية، حيث نسب لتميم: أحزن في مقابل: حزن لقريش، وأحل في مقابل: حل لأهل الحجاز ، وأكن لأهل نجد، وأمض لتميم،

وأفنن لأسد وربيعة وقيس وتميخ وجميع أهل نجد، وأراب لهذيل (').

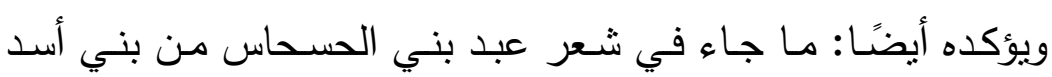

حيث نطق: أنهج في مقابل نهج، حيث فال:

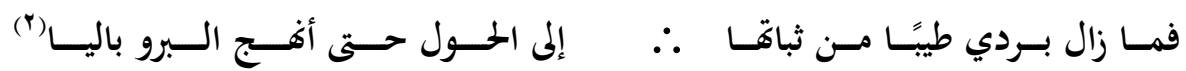
في حين جاءت الصيغة الثلاثية في قول الآخر :

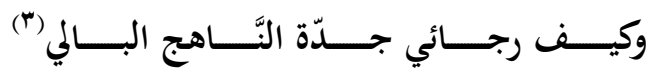

كما لا يخفى أنه فى النطق بـ(أفعل) بدلا من (فعل) انتقال من مقطع قصير مفتوح إلى متوسط مغلق في بداية الكلمة. $\{\hat{1} \mathbf{0}$

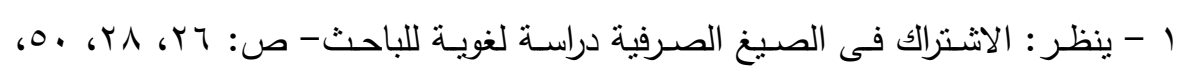

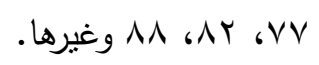

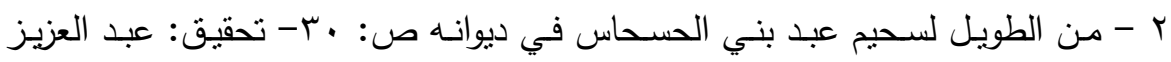

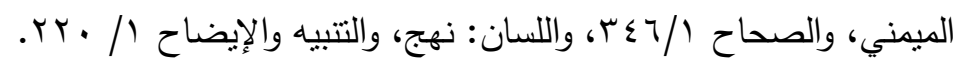

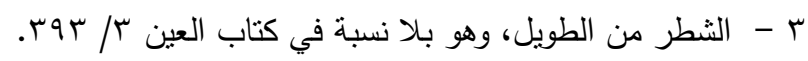




\section{"أنا" وإجرائ الوصل مجراه همراه}

يختلف العلماء في أصالة الألف الأخيرة في ضمير المتكلم "أنا" وزيادتها وذلك وتلك الاختلاف تابع لنطق العرب للضمير في الوصل والوقف، فالبصريون يرون

أنها زائدة بينما يراها الكوفيون أصلية (') فالحجازيون يثبتون الألف الأخيرة في حال الوقف ويحذفونها في حال الوصل يلان

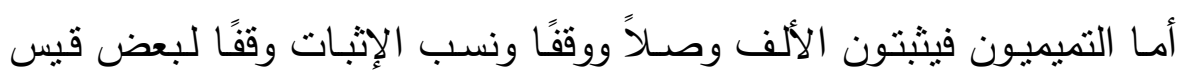

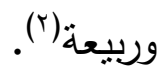
وقد جاء القراءة القرآنية لنافع بإثبات الألف في كل آية وردت فيها اللفظة في القرآن الكريم، وجاء عليها قول الثاعر:

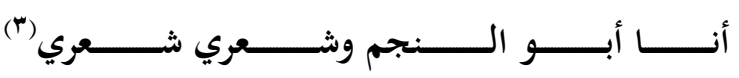

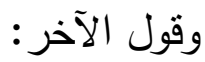

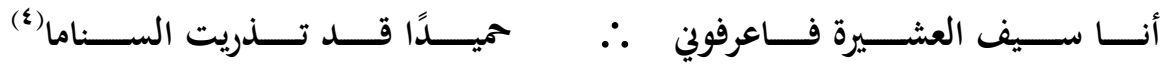
وخرجت هذه الأشـعار وأمثالها على أنها من إجراء الوصل مجرى الوقف، على لغة تميم وبعض قيس ذوربيعة، وخرجها بعضهم على الضرورة؛

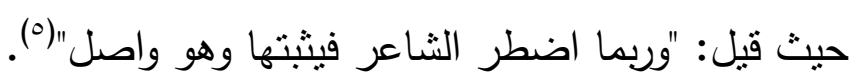
موقف شعرائ أسد من الظاهرة:

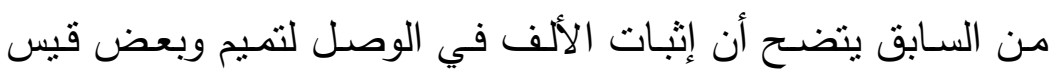

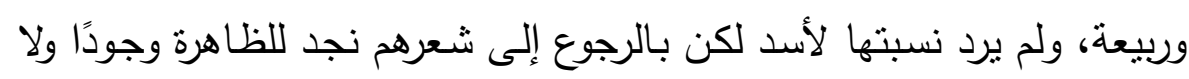

$$
\begin{aligned}
& 1 \text { - ينظر : المنصف لابن جني / 9، . 1. }
\end{aligned}
$$

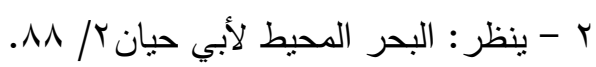

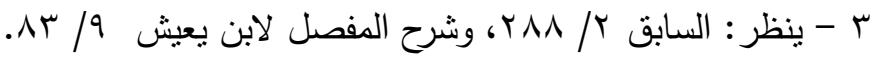

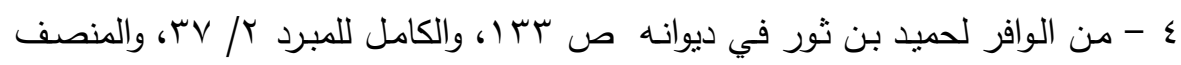

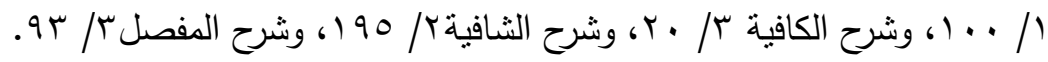

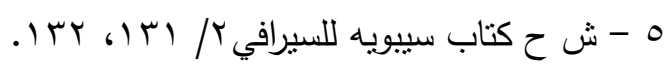




\section{حوليت كليت اللغتّا العربيتبايتاى البارود (العدد التاسع والعشرون)}

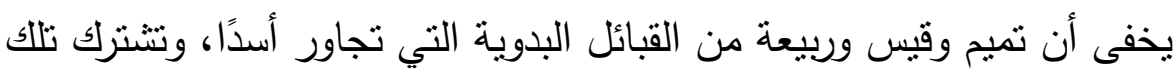
القبائل في كثثير من الخصائص اللهجية ومن مجيئ الظاهرة في لهجة أسد ما ورد في ديوانهم، من ذلك قول الثاعر:

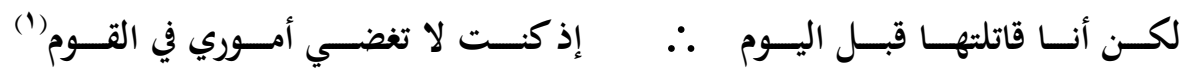

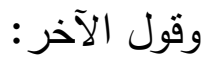

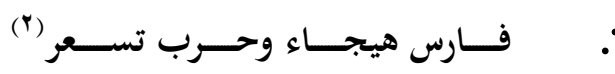

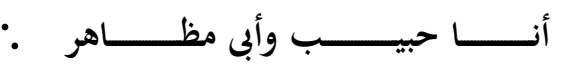

وقول طليحة بن خويلد: ابل

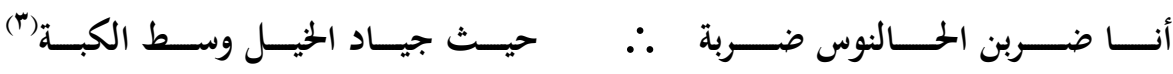
الصيغة في الساميات وأين المحدثين:

صيغة الضمير في العربية تتسب إلى حد كبير الصيغة في الساميات الأخرى ففي العبرية as hiani، وفي السينية المعنتة ane ، وفي الآرامية

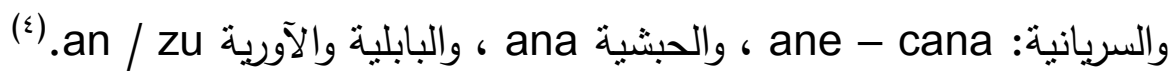

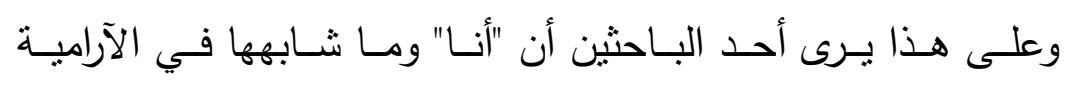
والحبشية: "ana" مكونـة من الضمير "أ" المتصل بالمضارع والنهاية الإشـارية "نا"، وهو بهذا ينتصر للغة تميم، ومذهب الكوفيين معتمدًا على وجود الصيغة في الساميات الأخرى(0). وكذا ذكر د/ لفيسون أن الضمير "أنا" في اللغات هو الهمزة والنون

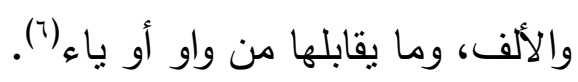

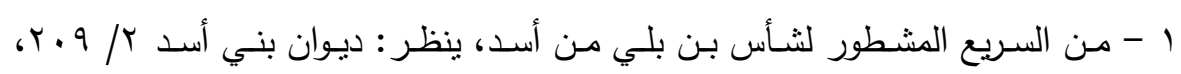

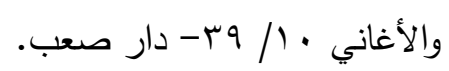

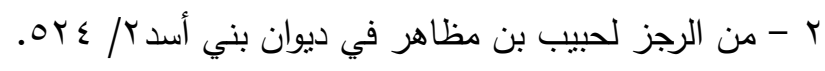

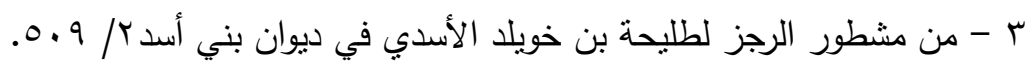

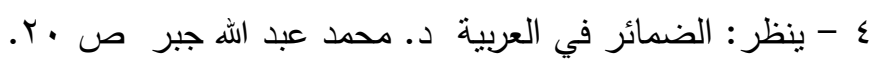

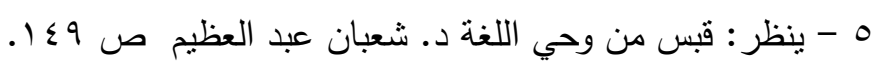

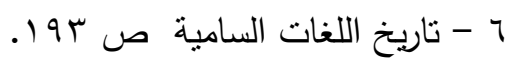


ملامح التزكيب والبنية في لغة بنى أسد في ضوء الشواهد الشعرية

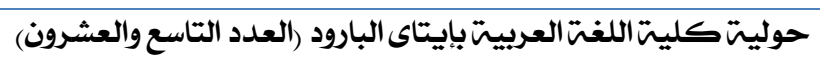

ويؤيد هذا الدكتور/شـعبان عبد العظيم أن اتفاق العربيـة والآراميـة

والأكادية والعبرية في وجود المد دليل على أنه أصلي (').

وهذا يعني أن القبائل البدوية شاركت الساميات الأخرى في الاحتفاظ

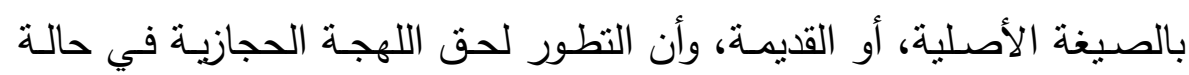

الوصل بأن حذفت الألف.

\section{$\{\hat{1} \mathbf{0}\}$}




\section{ثبت بأهم مصادر البحثي بائاى}

- ارتشاف الضرب من لسان العرب لأبي حيان تح/ د/ مصطفى أحمد النماس

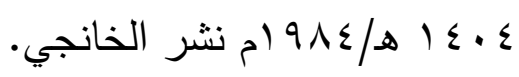

- إعراب القرءان للنحاس، تح: زهير غازي ط/ الثانية- دار الكتب- بيروت.

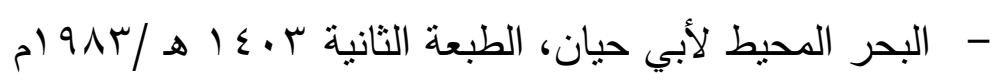

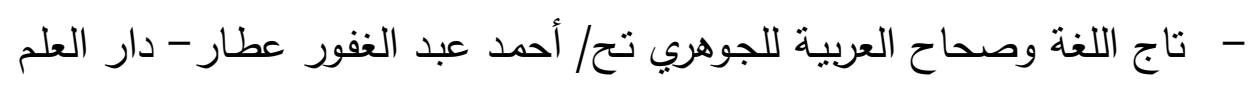
للملايين - بيروت.

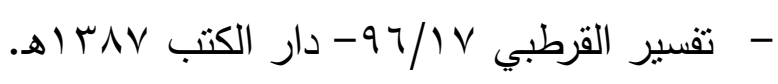

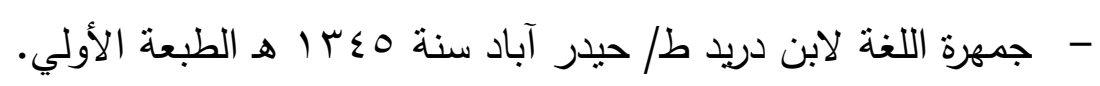

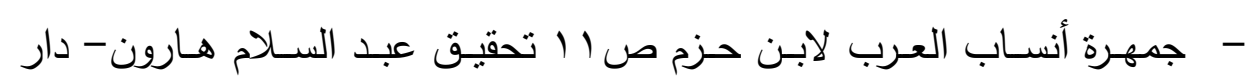

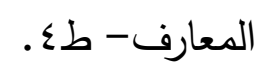

- سر صناعة الإعراب لابن جني تح/د/ حسن هنداوي ط/ دار القلم- دمشق

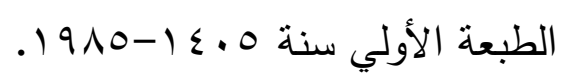

- الصـاحبي في فقه اللغة لأبي الحسن أحمد بن فارس ، تحقيق/ السبد أحمد صقر مطبعة/عيسى الحلبي.

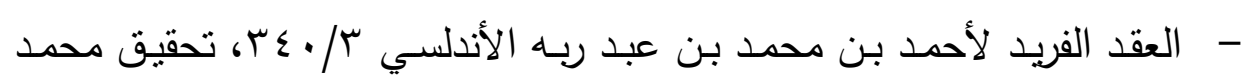

$$
\text { سعيد العريان - دار الفكر - بيروت- بدون. }
$$

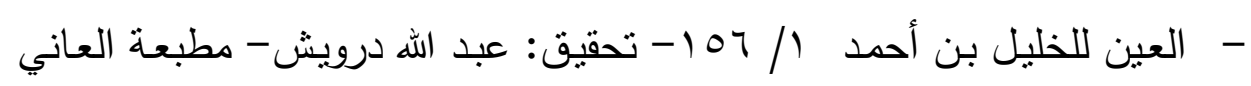

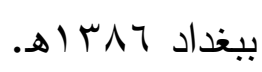

- قبس من وحي اللغة د/ شعبان عبد العظيم ، الطبعة الأولي، مطبعة الأمانة

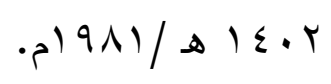

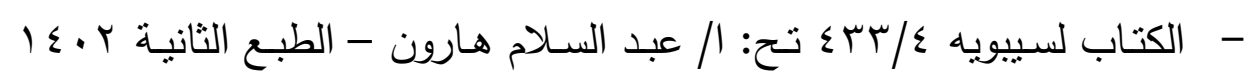
هـ/ 9 ام طبعة دار الجيل. - لسان العرب لابن منظور / / م طبعة دار المعارف. 


\section{ملامح التزكيب والبنية في لغة بنى أسد في ضوء الشواهد الشعرية}

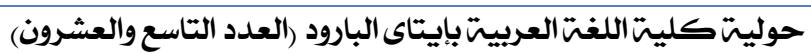

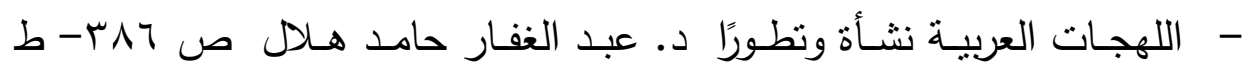
الثالثة • إ (هـ، .99 19 - مطبعة الجبلاوي.

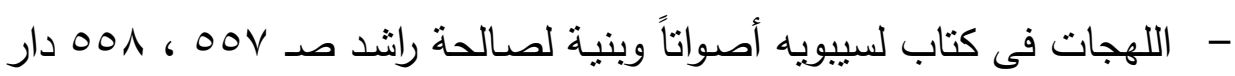
المدنى جدة ط أولى سنة 0 . ؛ اهـ .

- مختصر شواذ القراءات لابن خالويه، نشر براجستراسر، مطبعة المتتبي بغداد.

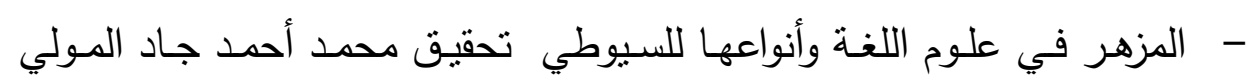
وعلي محمد البجاوي، ومحمد أبو الفضل إبراهيخ- دار إحياء الكتب العربية -

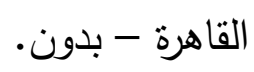

- مشارق الأنوار علي صحاح الآثار للقاضي عياض - طا دار التراث بالقاهرة .

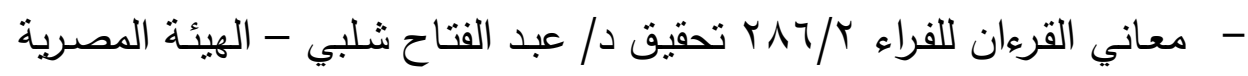

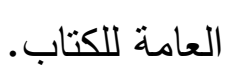

- معجم قبائل العرب القديمـة والحديثة لعمر رضـا كحالـة، مؤسسـة الرسـالة-

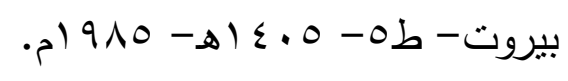

- المقتضب لأبي العباس المبرد تح/ محمد عبد الخالق عضيمه، ط/ المجلس الأعلي للشؤون الإسلامية.

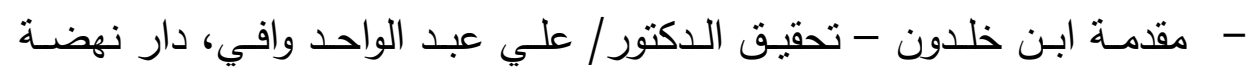

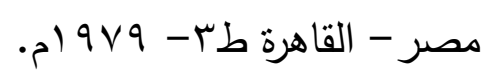

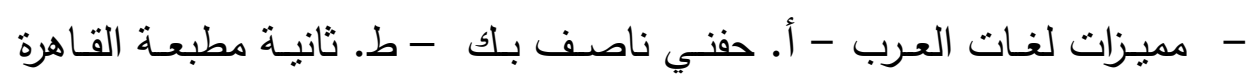

$$
\text { . } 190 \mathrm{~V}
$$

- همع الهوامع للسيوطي - دار الكتب العلمية بيروت لبنان.

\section{-}


